UNIVERSIDADE DE SÃO PAULO

FACULDADE DE FILOSOFIA, LETRAS E CIÊNCIAS HUMANAS

DEPARTAMENTO DE GEOGRAFIA

PROGRAMA DE PÓS-GRADUAÇÃO EM GEOGRAFIA HUMANA

GISÉLIA PINHEIRO DOS REIS

Cartografia Temática aplicada à análise ambiental do município de Juquitiba - SP

SÃO PAULO

2016 


\author{
UNIVERSIDADE DE SÃO PAULO \\ FACULDADE DE FILOSOFIA, LETRAS E CIÊNCIAS HUMANAS \\ DEPARTAMENTO DE GEOGRAFIA \\ PROGRAMA DE PÓS-GRADUAÇÃO EM GEOGRAFLA HUMANA
}

GISÉLIA PINHEIRO DOS REIS

Cartografia Temática aplicada à análise ambiental do município de Juquitiba - SP

(Versão Revisada)

\begin{abstract}
Dissertação de Mestrado apresentada ao Departamento de Geografia da Faculdade de Filosofia, Letras e Ciencias Humanas da Universidade São Paulo para a obtenção do título de Mestre em Geografia Humana.
\end{abstract}

Orientador: Mario De Biasi

De acordo:

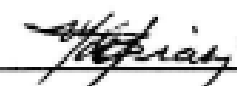

SĀO PAULO

2016 
Autorizo a reprodução e divulgação total ou parcial deste trabalho, por qualquer meio convencional ou eletrônico, para fins de estudo e pesquisa, desde que citada a fonte.

Catalogação na Publicação

Serviço de Biblioteca e Documentação

Faculdade de Filosofia, Letras e Ciências Humanas da Universidade de São Paulo

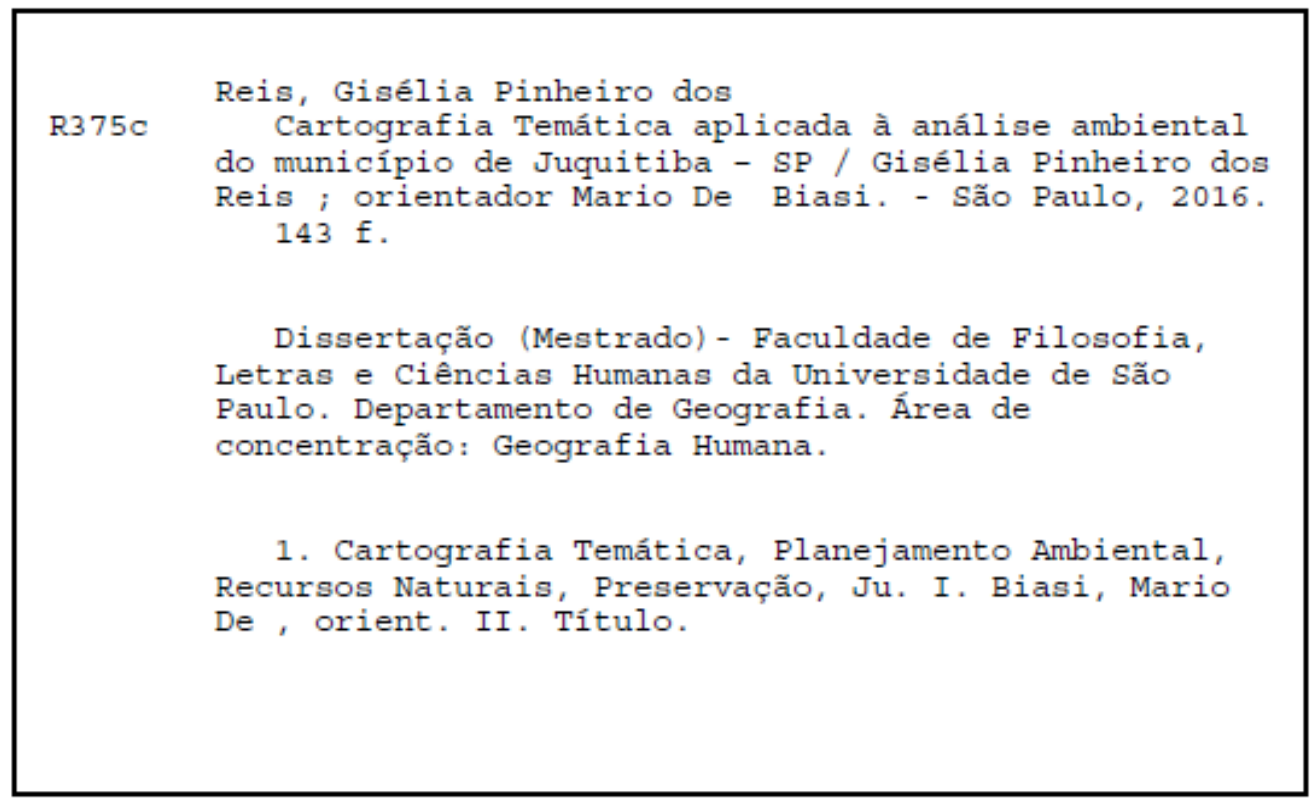


Nome: REIS, Gisélia Pinheiro dos.

Título: CARTOGRAFIA TEMÁTICA APLICADA À ANÁLISE AMBIENTAL DO

MUNICÍPIO DE JUQUITIBA

Dissertação de Mestrado apresentada ao

Departamento de Geografia da Faculdade de

Filosofia, Letras e Ciências Humanas da

Universidade São Paulo para a obtenção do título de Mestre em Geografia Humana.

Aprovada em:

Banca examinadora:

Mario De Biasi Instituição: Universidade de São Paulo

Paulo Roberto Moraes Instituição: PUC - SP

Fernanda Padovesi Fonseca Instituição: Universidade de São Paulo 
Dedico este trabalho

Ao meu pai, José, e à minha mãe, "dona Nô", pelo incentivo e apoio incondicional em todos os momentos da minha vida.

Ao meu marido Jefferson, que com toda dedicação e apoio não me deixou desistir nem desanimar perante os obstáculos naturais quando se caminha em busca de crescimento pessoal e profissional.

À minha pequenina Juju, que me lembra todos dias que a vida é boa demais e que tudo vale a pena. 


\section{AGRADECIMENTOS}

Infinita gratidão ao prof. Dr. Mario De Biasi, que possibilitou que eu vivesse essa humilde e gratificante experiência cartográfica. Pelo apoio, incentivo, estímulo e paciência, que me propiciaram um grande aprendizado que repercutiu não só na realização deste trabalho, mas que me tornou uma pessoa mais humana e otimista diante das adversidades da vida.

À Profa. Dra. Fernanda Padovesi Fonseca e ao Prof. Dr. Reinaldo Paul Pérez Machado pela participação na banca do exame de qualificação, momento no qual fizeram importantes contribuições ao desenvolvimento deste trabalho.

Ao Prof. Dr. Paulo Roberto Moraes pelas contribuições durante a participação na banca

Às minhas irmãs Silvia, Paula e Elaine que cuidaram com todo amor da pequenina Juju quando minha ausência se tornou necessária.

À minha mãe "dona Nô" que tornou possível a realização deste trabalho ao dedicar cuidado, carinho e amor à minha filha quando minha ausência se tornou imprescindível.

Ao meu esposo amado Jefferson pela compreensão, paciência e infinitos adjetivos que possibilitaram a realização deste trabalho.

Ao meu cunhado André Fernando pelo apoio na instalação dos programas utilizados na execução deste trabalho.

Aos meus amigos queridos Ieda, Giu e Zé Uelton: um por todos e todos por um. Muito me orgulho de compartilhar a experiência docente com eles.

À Patrícia do Prado Oliveira, uma pessoa humilde e iluminada que providencialmente entrou no meu caminho para reforçar minhas convicções e abrir meus horizontes para outras possibilidades, principalmente na caminhada acadêmica. 
A água serpeia entre musgos seculares. Leva um recado de existência a homens surdos E vai passando, vai dizendo Que esta mata em redor é nossa companheira, É pedaço de nós florescendo no chão.

\section{Carlos Drummond de Andrade}


A Cartografia Temática permite múltiplas análises do espaço geográfico de forma mais complexa, uma vez que suas abordagens são fruto de conhecimentos interdisciplinares e serve a diferentes saberes. Tem se constituído num importante instrumento de compreensão da conjuntura ambiental que se encontra em cenário de crise, em decorrência dos usos inadequados, sem o devido planejamento, dos recursos naturais numa trajetória histórica que visava a exploração desenfreada e a conquista das florestas brasileiras, principalmente a Mata Atlântica, que atualmente se reduz a parques e reservas totalmente fragmentados. $\mathrm{O}$ comprometimento da qualidade e da disponibilidade dos recursos naturais pressiona cada vez mais a sociedade civil e o poder público a pensar novos paradigmas que contemplem a recuperação de ambientes degradados e a preservação de recursos naturais. A Cartografia Temática, com suas variáveis ambientais, tem como pressuposto metodológico a teoria sistêmica, que tem como premissa espacializar, na forma de síntese ou de análise, os diferentes cenários ambientais considerando seus aspectos de forma inter-relacionada e integrada, superando a visão mecanicista e positivista que sustentou o conhecimento científico por vários séculos. Por meio desta concepção metodológica, a Cartografia Temática tem subsidiado o planejamento ambiental, prática obrigatória e validada nos municípios pelos planos diretores, que são respaldados por uma vasta legislação ambiental que vem se consolidando nas últimas quatro décadas. Este trabalho faz uma reflexão sobre a importância da Cartografia Temática que viabiliza a elaboração de cenários ambientais para a prática do planejamento e do ordenamento do território no município de Juquitiba - SP, sob as vigências das leis ambientais que incidem diretamente sobre a organização das atividades relacionadas ao uso e ocupação do solo no município que abriga a maior reserva de Mata Atlântica da Região Metropolitana de São Paulo. Por meio de mapas temáticos, os principais aspectos físicos do município são analisados de forma sistêmica. Para cumprir com a abordagem holística intrínseca a este trabalho utilizaram-se o SIG QGIS e imagens de satélites disponibilizadas pelo INPE. Estes instrumentos são imprescindíveis á análise ambiental, uma vez que permitem maior integração entre as diferentes informações sobre o tema através do banco de dados, otimizam o tempo e custo na obtenção das informações, permitem a constante atualização dos dados e contribuem para o dinamismo da Cartografia Temática.

Palavras-Chave: Cartografia Temática, Planejamento Ambiental, Recursos Naturais, Preservação, Juquitiba. 


\begin{abstract}
The Thematic Cartography allows multiple analysis of a geographic space of more complex shapes, once that yours approach are fruit of interdisciplinary knowledge and serves to different knowledge. It has been composed from important instruments of understanding of environmental juncture that are find in crisis scenery, as a result of improper use without due planning of natural resources in a historic trajectory that aimed the unbridled exploration and conquest of Brazilian forest, principally the Mata Atlântica, that currently reduced in parks and reserves and totally fragmented.

The quality commitment and of availability natural resources pressed increasingly the civil society and the public power to think news paradigms that observe the recovery of degraded environments and preservation of natural resources. The Thematic Cartography with its environmental variables have like methodological presupposed the systems theory have like premise spatialize in the form of synthesis or of analysis, the different environmental scenery considering yours aspects interrelated and integrated, overcoming the mechanistic and positivist view that sustained the scientific knowledge for several centuries. By means of this methodological conception, the environmental cartography have subsidy the environmental planning, obligatory practice mainly in municipal district through of the directors plans, supported by a wide environmental legislation that come consolidating the past four decades. This work is a reflection about the importance of Thematic Cartography that enables the development of environmental scenery to practice of planning and of spatial planning in county of Juquitiba - SP. Under the validity of environmental laws that affect directly on the organization of activities related to the use and land use in the city, which houses the largest reserve of Mata Atlântica of Metropolitan area of São Paulo. Through thematic maps of main physical aspects of the county are analyzed systemically. To comply with the approach intrinsic holistic this work was done using SIG QGIS and satellite images provided by INPE. These instruments are essential in environmental analyses once they allows greater integration between the different information on the topic through the database, optimize the time and cost in obtain of the information, allows constant updating of data, contributing to the dynamism of thematic cartography.
\end{abstract}

Keywords: Thematic Cartography, planning, natural resources, preservation, Juquitiba. 


\section{LISTA DE FIGURAS}

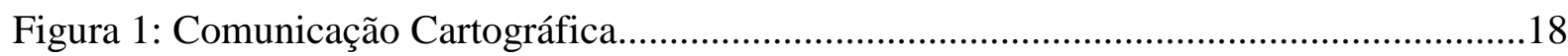

Figura 2: Localização do município de Juquitiba - SP ............................................................83

Figura 3: Unidades de Conservação no município de Juquitiba - SP......................................89

Figura 4: Parque Estadual da Serra do Mar - Núcleo Curucutu - limites com o município de

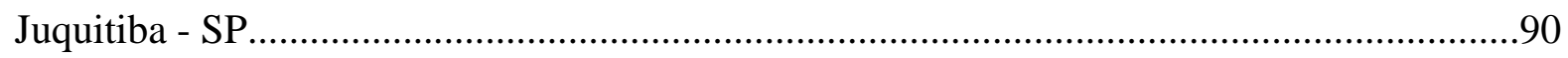

Figura 5: Parque Estadual do Jurupará - limites com o município de Juquitiba - SP.............94

Figura 6: Mapa de declividade no município de Juquitiba - SP...........................................106

Figura 7: Mapa Relevo no município de Juquitiba - SP.......................................................107

Figura 8: Mapa de solo no município de Juquitiba - SP......................................................108

Figura 9: Mapa de Cobertura Vegetal no município de Juquitiba - SP................................111

Figura 10: Mapa de uso do solo no município de Juquitiba - SP ........................................112

Figura 11: Bromélias Bairro das Laranjeiras município de Juquitiba - SP...........................113

Figura 12: Vegetação Densa no município de Juquitiba - SP.............................................113

Figura 13: Capoeira + Mata no município de Juquitiba - SP................................................113

Figura 14: Vegetação de várzea - estrada dos padeiros ........................................................114

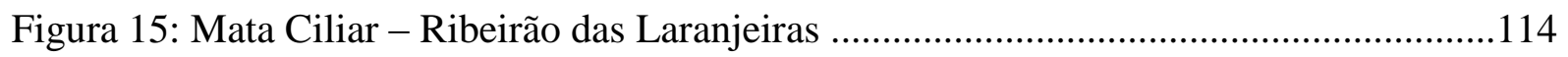

Figura 16: Mapa das sub-bacias no município de Juquitiba.............................................119

Figura 17: Mapa da Rede de Drenagem no município de Juquitiba.....................................120

Figura 18: Mapa de Zoneamento Ambiental no município de Juquitiba..............................124 


\section{LISTA DE QUADROS}

Quadro 1 - Variáveis visuais proposta por Bertin ................................................................ 21

Quadro 2 - Características da Cartografia Topográfica e Cartografia Temática .................... 27

Quadro 3 - Características das projeções cartográficas ........................................................31

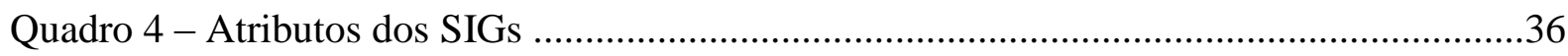

Quadro 5 - Principais intervalos espectrais e suas características ......................................42

Quadro 6 - Vantagens do sensoriamento remoto por radar ................................................... 48

Quadro 7 - Atividades humanas e respectivos impactos ambientais em ambientes aquáticos

Quadro 8 - Impacto ambiental de acordo com as diretrizes da resolução CONAMA 001/86 72

Quadro 9 - Uso e ocupação do solo no município de Juquitiba ...........................................86

Quadro 10 - Zoneamento terrestre: usos e diretrizes ....................................................... 125 
ACI - Associação Cartográfica Internacional

APA - Área de Proteção Ambiental

APP - Área de Preservação Permanente

CONAMA - Conselho Nacional do Meio Ambiente

DAEE - Departamento de Águas e Energia Elétrica

DBMS - Database Management System

EMBRAPA - Empresa Brasileira de Pesquisa Agropecuária

ETA - Estação de Tratamento de Água

IBAMA - Instituto Brasileiro do Meio Ambiente e dos Recursos Naturais Renováveis

INPE - Instituto Nacional de Pesquisar Espaciais

IBGE - Instituto Brasileiro de Geografia e Estatística

IPA - Índice de Pressão Antrópica

LIDAR - Light Detection and Ranging

MDE - Modelo Digital de Elevação

PEJU - Parque Estadual do Jurupará

PESM - Parque Estadual da Serra do Mar

RADAR - Radio Detection and Ranging

REM - Reflexão Eletromagnética

EIA RIMA - Estudo de Impacto Ambiental Relatório de Impacto Ambiental

SAR - Synthetic Aperture Radar

SEMA - Secretaria Estadual do Meio Ambiente

SIG - Sistema de Informação Geográfica

SIM - Sistema Integrado Metropolitano

SISNAMA - Sistema Nacional do Meio Ambiente

SNUC - Sistema Nacional de Unidades de Conservação

SONAR - Sound Navigation and Ranging

SPSL - Sistema Produtor São Lourenço

SRTM - Shuttle Radar Topography Mission

RMSP - Região Metropolitana de São Paulo

UGRHI - Unidade de Gerenciamento de Recursos Hídricos

ZEE - Zoneamento Ecológico - Econômico 


\section{SUMÁRIO}

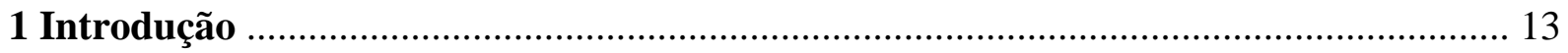

2 Cartografia

2.1 Considerações sobre o desenvolvimento da ciência cartográfica ...................................... 16

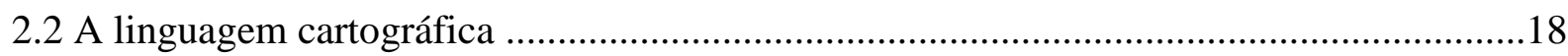

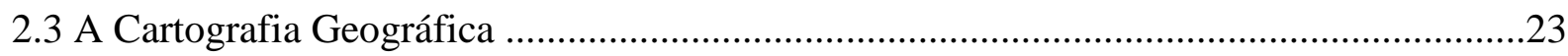

2.4 A Cartografia Temática ………………………………………………………...26

2.5 Os cenários ambientais na Cartografia Temática …………………………………...... 28

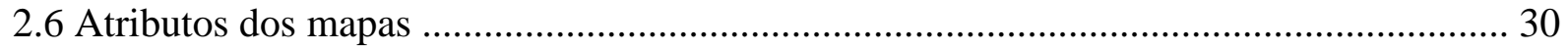

2.7 Sistema de Informação Geográfica .............................................................................33

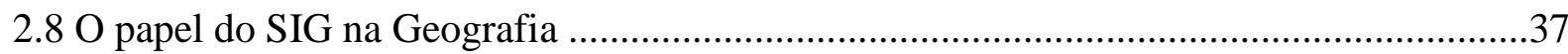

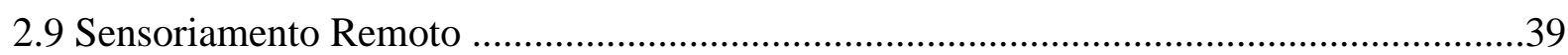

2.10 Características dos principais sistemas sensores orbitais em operação .............................44

2.10.1 Características do Sistema Radar ............................................................................ 46

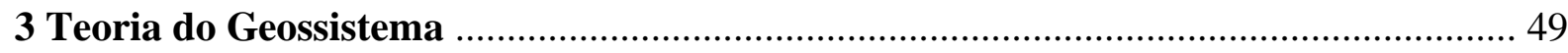

3.1 Paradigmas da ciência moderna ………………………............................................4

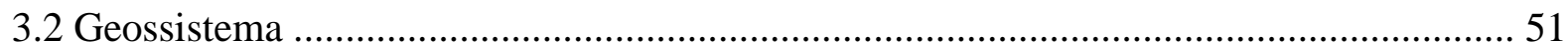

3.3 A Cartografia na teoria geral dos sistemas ................................................................. 54

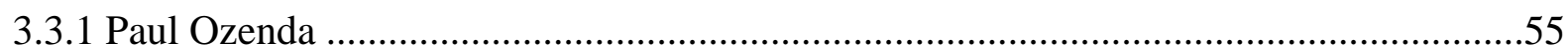

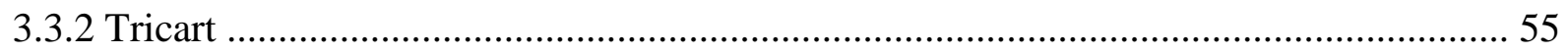

3.4 Principais características do meio físico numa abordagem sistêmica .................................57

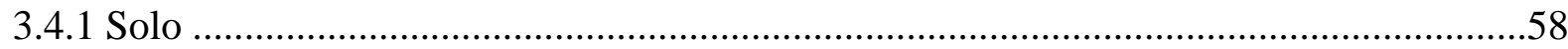

3.4.2 Fatores que influenciam na formação do solo ........................................................... 59

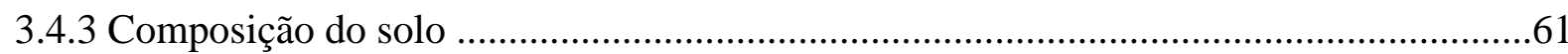

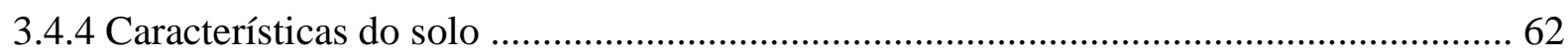

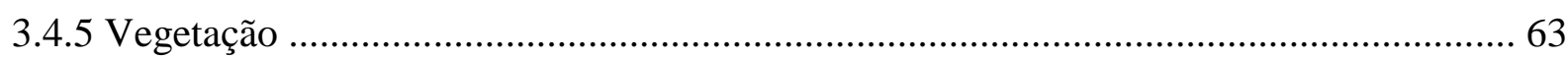

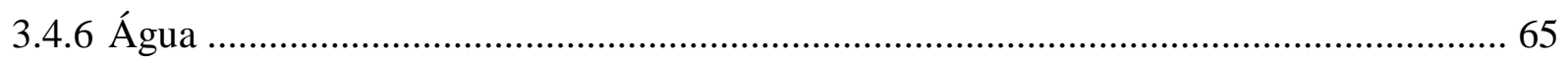

3.4.7 Bacia hidrográfica ………………………………………………………….... 70

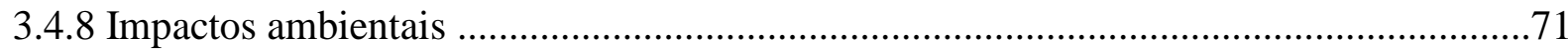

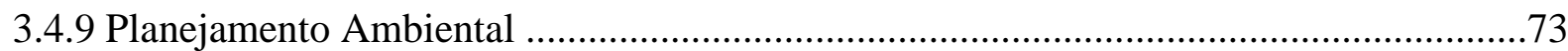

3.4.10 Planejamento Ambiental no Brasil ..................................................................... 75 
4 Município de Juquitiba: uma reserva de mata atlântica ..............................................80

4.1 Fatores Geomorfológicos que contribuíram para a formação da mata atlântica ............... 80

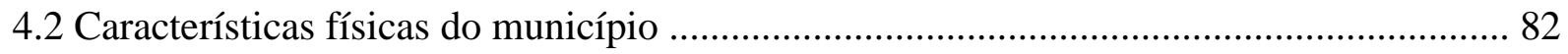

4.3 Processo de formação e ocupação do território de Juquitiba ..............................................84

4.4 Atividades econômicas e impactos ambientais no município de Juquitiba ...................... 85

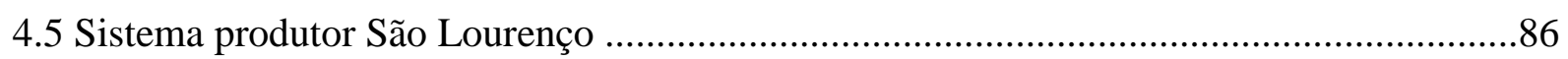

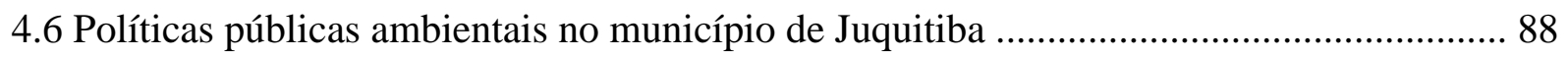

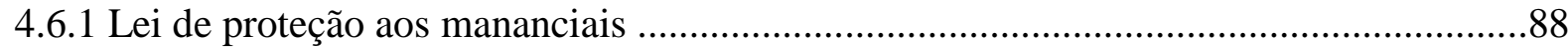

4.6.2 Unidades de conservação no município de Juquitiba ................................................. 89

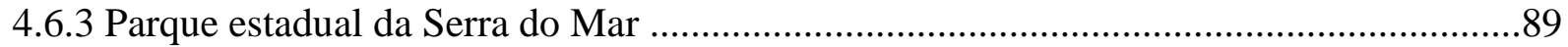

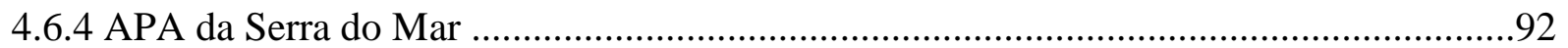

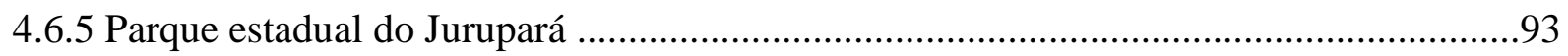

4.6.6 Plano diretor do município e o planejamento ambiental ............................................96

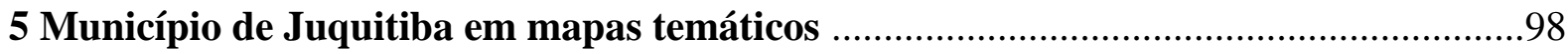

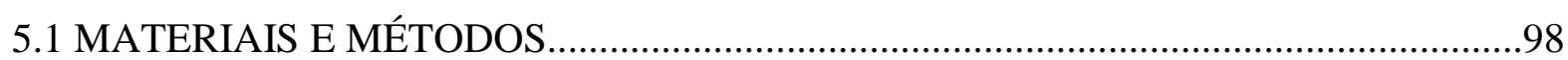

5.1.1 Cartografia Temática na elaboração de cenários ambientais.........................................98

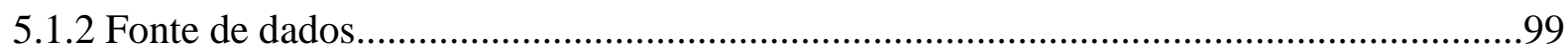

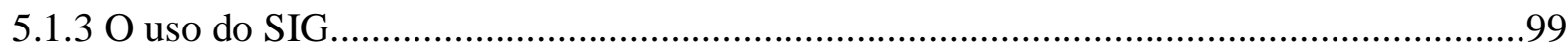

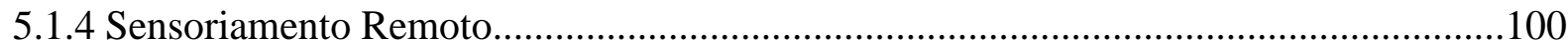

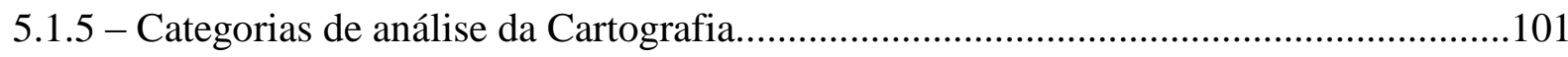

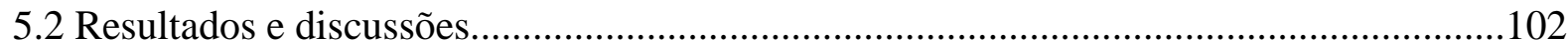

5.2.1 Aspectos gerais do estudo da declividade, relevo e tipos de solo................................102

5.2.2 Aspectos da Cartografia Temática aplicada à análise dos cenários ambientais.............105

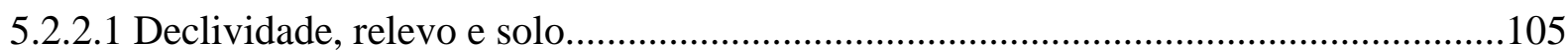

5.2.2.2 Vegetação e uso e ocupação do solo.....................................................................110

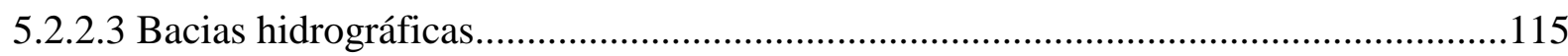

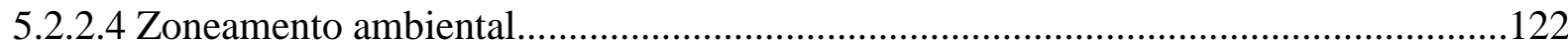

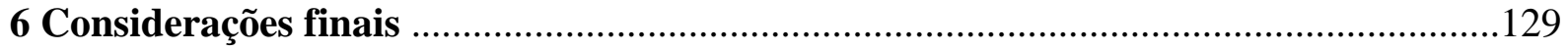

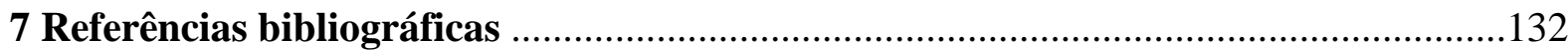




\section{Introdução}

A necessidade de representação de fenômenos que ocorrem no espaço geográfico e de sua localização está presente na condição humana desde os primórdios de sua evolução e se configura como uma linguagem antes mesmo da expressão escrita. O homem deixou registrado através de pinturas rupestres e desenhos a leitura e as observações que ele mesmo realizou do espaço vivido, contribuindo para um conhecimento efetivo do espaço terrestre.

Com as transformações ocorridas no espaço, os métodos de registro e observações dos lugares se diversificaram, conservando seu objetivo primordial que é a representação de fenômenos em seus aspectos qualitativos e quantitativos e sua localização.

A cartografia acompanha a dinâmica da moderna sociedade capitalista. Através das diversificadas técnicas de representação, amparadas pelos SIGs e Sensoriamento Remoto, as abordagens temáticas da cartografia têm contribuído para aprofundar as leituras do espaço geográfico, que tem sofrido intensas transformações em função das demandas do sistema econômico vigente.

A complexidade dos fenômenos que ocorrem no espaço geográfico tem exigido dos pesquisadores e estudiosos uma nova postura metodológica que permite uma visão integrada dos fenômenos superando a lógica mecanicista e positivista que subsidiou os conhecimentos científicos por vários séculos. A cartografia em suas abordagens temáticas - ambientais adota a concepção sistêmica para explicar de forma mais aprofundada os problemas que ocorrem no meio ambiente que se mantém em equilíbrio dinâmico. A exploração indiscriminada dos recursos naturais tem afetado esse equilíbrio comprometendo a qualidade e a preservação dos diferentes recursos bióticos e abióticos que compõe o extrato geográfico, o que contribui para um cenário de crise ambiental.

Após vários séculos de exploração das matas de forma predatória, o poder público no Brasil, nas quatro últimas décadas, tem apresentado uma legislação mais incisiva direcionada ao planejamento ambiental. A concepção sistêmica e a Cartografia Temática têm subsidiado o planejamento porque contempla de forma mais profunda a complexidade das questões ambientais presentes na sociedade moderna.

Há uma crescente preocupação com as condições do equilíbrio dinâmico do meio físico tanto pela sociedade civil quanto pelo poder político, visto que a sociedade moderna está cada vez mais dependente dos recursos naturais. Uma vez alterados, comunidades e ecossistemas podem ser extintas ou modificadas de forma irreversíveis. Nessa perspectiva, faz-se necessária uma análise de forma rigorosa e integrada do mesmo. 
O estudo do meio físico se utiliza de técnicas e instrumentos informatizados, como o geoprocessamento e o sensoriamento remoto, que favorecem a elaboração de mapas temáticos, permitindo uma análise e prevenção dos problemas desencadeados na área. Auxilia no planejamento adequado para o manejo de áreas potencialmente degradadas como assoreamento de redes de drenagem, áreas propensas à erosão e monitoramento de queimadas e desmatamento.

O município de Juquitiba, localizado no estado de São Paulo, está inserido num meio físico que possui diversas riquezas naturais. Seus recursos hídricos são totalmente protegidos pela Lei Estadual $\mathrm{N}^{\circ}$ 9.866, Lei de Mananciais, desde a década de 1970, que incide diretamente sobre o parcelamento do solo e um efetivo planejamento ambiental obrigatório e respaldado por leis federais que culmina com o plano diretor municipal.

Os diversos rios que se encontram no município, as numerosas nascentes, riachos, cachoeiras e represas constituem um atrativo turistíco para todo o estado de São Paulo. O turismo é uma atividade que desempenha um papel econômico importante na região e precisa ser exercida respeitando os limites da natureza. Diante disso, torna-se necessário conhecer as políticas públicas que asseguram a preservação e o gerenciamento dos recursos naturais do município e conhecer os principais impactos ambientais provocados na região em consequência do desenvolvimento de atividades de pesca, trilhas, construção de pousadas e outras formas de uso e ocupação do solo no município.

A biodiversidade, principal carcterística do Bioma de Mata Atlântica, desperta interesse econômico e científico em entidades locais e de outras regiões do estado. Devido à intensa exploração para os diversos fins, que vem sofrendo desde os primórdios da colonização e à crescente demanda pela utilização dos recursos naturais do município, é de extrema relevância o conhecimento das causas e consequências das formas de devastação do meio físico desta região e o conhecimento dos fatores que causam o seu esgotamento, visto que, o meio físico se constitui em um equlibrio dinâmico, daí a importância do estudo de forma integrada de seus aspectos: solo, clima, vegetação e relevo.

O uso do solo constitui em diversas escalas um dos aspectos que sofre interferência direta da ação humana. Sem o planejamento adequado de manejo, pode-se causar o seu esgotamento e erosão, compromentendo a qualidade e disponibilidade dos recursos hídricos e da manutenção dos ecossistemas locais. As culturas que remetem à utilização da terra devem obedecer às potencialidades e fragilidades do meio físico da região. 
Segundo o IBGE, 2002, os recursos hídricos do município são afetados diretamente pelo despejo de resíduos industriais, esgoto doméstico, resíduos sólidos, ocupação irregular em cursos d'água e em áreas de lençóis subterrâneos e degradação de mata ciliar. A contaminação do solo acontece por chorume e sumidouros e a paisagem vem sofrendo alterações devido aos grandes empreendimentos imobiliários implantados na região, por ocupação irregular e desordenada do solo.

O modelo de desenvolvimento da atualidade perpassa pela manutenção da qualidade dos recursos naturais, garantia de vida saudável para as futuras gerações, da qual, todos devem dispor da utilização racional dos mesmos. Isso demanda um envolvimento consciente da sociedade civil, das autoridades políticas e de diversos setores da economia. Urge, pois, repensar as ações humanas desencadeadas no meio natural e a forma predatória com que a sociedade moderna se relaciona com a natureza.

Como objetivo geral este trabalho busca compreender os processos naturais que contribuíram para a formação dos mananciais do município de Juquitiba - SP e de que forma o poder público e a comunidade local gerenciam seus recursos hídricos, aplicando técnicas de Cartografia Temática. Do objetivo principal desdobram-se os seguintes objetivos específicos: caracterizar as condições naturais do município de Juquitiba - SP e conhecer as políticas públicas que gerenciam os recursos hídricos do município; - Identificar as principais formas de uso e ocupação do solo e a distribuição da vegetação natural em áreas de proteção ambiental através de técnicas de Sensoriamento Remoto e SIGs e utilizar mapas temáticos na elaboração de cenários ambientais e inferir sobre sua aplicação ao planejamento ambiental no município de Juquitiba - SP. 


\section{Cartografia}

2.1 Considerações sobre o desenvolvimento da ciência cartográfica

A sistematização dos conhecimentos sobre o planeta Terra, desde a antiguidade clássica, consolidou os alicerces para o desenvolvimento das ciências, entre elas a Cartografia. Assim, enquanto saber, a ciência cartográfica evoluiu junto com a necessidade do homem de ampliar seus horizontes geográficos: a busca por novas terras e a conquista de novas fontes de riqueza, as relações comerciais entre os países vizinhos e posteriormente com os mais distantes, consequência da expansão marítima que contribuiu para que a Cartografia adquirisse ao longo do processo histórico características técnicas, renovando seus métodos e refletindo a influência de diferentes povos.

O acumulado destes conhecimentos no decorrer da história, agregado às novas descobertas sobre os diferentes povos e terras da América, Ásia e África culminaram com a colonização dos seus territórios. Os mapas se tornaram armas tão poderosas quanto os canhões e os navios de guerra, contribuindo para a legitimação do poder vigente (HARLEY, 2009). De acordo com este autor, esta foi a temática da Cartografia durante diferentes períodos históricos "os mapas serviram para promover a política colonial e onde os territórios foram reivindicados no papel antes de ser efetivamente ocupados, os mapas anteciparam o império". (HARLEY, 2009, p. 5)

Conforme as relações sociais se tornaram complexas, o uso e produção de mapas também acompanhou essa dinâmica. As maiores conquistas territoriais empreendidas pelas nações europeias se apoiaram nos mapas para legitimá-las, planejá-las e executá-las. As cartas náuticas produzidas por navegadores e para a navegação registravam a princípio, no século XIII rotas comerciais (Portulanos criados por navegantes italianos). À medida que as viagens marítimas aconteciam, novos conhecimentos sobre territórios, povos, rotas, acidentes geográficos, cálculos de distância foram incorporados às produções cartográficas. A navegação favoreceu o desenvolvimento da cartografia moderna com a incorporação de instrumentos que aprimoravam a orientação em alto mar e conferiram maior precisão às distâncias representadas nos mapas.

Gerardus Mercator revolucionou os métodos de representação cartográfica ao sistematizar o sistema de projeção com propriedades matemáticas e geométricas que conservam os ângulos (projeção conforme - mantém as direções). De acordo com LIBAULT 
(1967, p. 07) "sua projeção é consequência da lógica do sistema Portulanos. Desde que os ângulos dos rumos sejam apreciados, a partir de linhas paralelas, todas as direções de navegação são loxodrônicas e a conformidade segue naturalmente”. A projeção de Mercator prevalece até os dias atuais, como uma conquista técnica na produção cartográfica, constituindo a base da cartografia moderna utilizada no Google Maps (FONSECA; OLIVA, 2013, p. 54).

Novos estudos e pesquisas têm tratado os documentos cartográficos como objetos técnicos, produtos de construções sociais e culturais e meios de comunicação dotados de linguagem visual própria, ciência cognitiva que envolve comunicação entre o cartógrafo e o usuário. As contribuições metodológicas envolvidas no processo de leitura e análise dos mapas que se consolidaram ao longo do processo de desenvolvimento da ciência cartográfica consideraram e valorizaram o contexto histórico em que os mesmos foram produzidos e atentam para o conhecimento da natureza das informações que neles foram inscritas. Mais do que a decodificação dos símbolos cartográficos, os mapas sinalizam fenômenos decorrentes das relações estabelecidas no espaço geográfico, fruto da vivência cotidiana do homem em diferentes períodos históricos.

O processo de criação e o uso de mapas são atividades que fazem parte de um mesmo processo denominado de comunicação cartográfica, e que sua efetivação depende da percepção visual. A comunicação cartográfica alcança os resultados esperados quando o uso dos mapas ocorre com base em conhecimentos que são comuns ao cartógrafo e ao usuário, caracterizados no modelo da Comunicação Cartográfica proposta Kolacny. Quando o uso dos mapas ocorre em situações nas quais não há a sobreposição de conhecimentos entre cartógrafo e usuário, a comunicação cartográfica é comprometida.

Os mapas projetam diferentes cenários, o que implica na utilização de diferentes linguagens, mas a particularidade a ser preservada é a comunicação com o usuário. Nesse sentido Kolacny define a Cartografia como teoria, técnica e prática de duas esferas de interesses: a criação e o uso dos mapas e defende que o cartógrafo deve conhecer além das necessidades e interesses dos usuários do mapa, a consciência do seu nível de habilidade e destreza, dos métodos que usam para trabalhar com o mapa, e também das condições ambientais nas quais o mapa será usado (Kolacny: 1994, p.4).

A comunicação cartográfica ocorre de forma eficiente quando a leitura do mapa permite um retorno à realidade representada pelo cartógrafo. A teoria de Kolacny evidenciou as circunstâncias em que este processo se desencadeia como o desenvolvimento cognitivo 
adequado que permite a abstração e a habilidade de decodificar os signos que compõe a linguagem cartográfica.

Figura 1. Comunicação da Informação Cartográfica

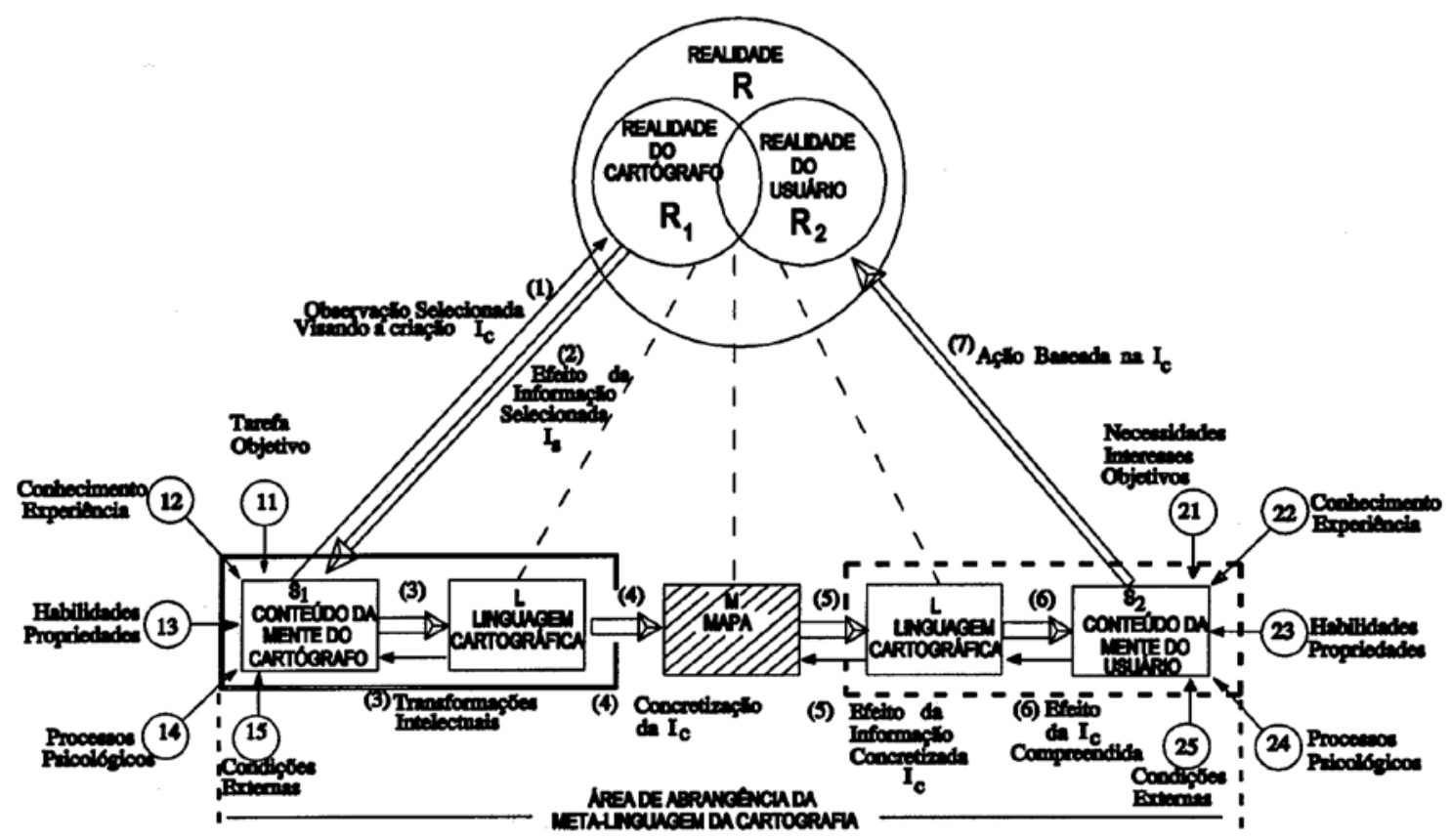

Fonte: Kolacny, Antonin, 1977 (apud Simielli, Maria Elena Ramos, 1986).

Nesta figura Kolacny expõe todos os fatores que atuam no processo de comunicação da informação cartográfica. As etapas necessárias à elaboração do mapa têm início com a observação do mundo visto pelo cartógrafo de forma selecionada e o mapa é a concretização desta informação. A leitura eficiente do mapa pelo usuário é consequência do conhecimento que ele possui da realidade representada pelo cartógrafo e do desenvolvimento dos processos psicológicos que culmina com a decodificação dos signos utilizados na representação que compõe a linguagem cartográfica enquanto sistema de regras e símbolos.

\subsection{A linguagem cartográfica}

Uma cartografia mais dinâmica vem se afirmando nesse período em que as relações socioeconômicas se tornam mais complexas devido ao novo modo de produção capitalista que foi se consolidando. Os mapas, na sua multiplicidade, são representações gráficas do espaço, 
possuem linguagem monossêmica com simbologia específica. Representam características qualitativas e quantitativas dos fenômenos que ocorrem no espaço geográfico.

As teorias que fundamentam a Cartografia enquanto saber científico permeado pela concepção de comunicação se consolidou a partir do século XX, entre as décadas de 60 e 70, sedimentando a corrente de pensamento denominada de Comunicação Cartográfica com diferentes eixos de pesquisas que afirmam a visão moderna da Cartografia. Dentre os autores pioneiros, nessa nova concepção, podemos destacar Bertin, Ratajski, Board e Salichtchev. O processo de comunicação cartográfica não envolve mais somente a produção do mapa, mas apresenta uma preocupação com o usuário final ao qual o mapa se destina.

Com Salichtchev (1954) aparece a preocupação com a figura do usuário com o processo metodológico que envolve os atos de fazer e usar o mapa. Board (1991) inclui a questão da informação georreferenciada conjuntamente com a questão da cartografia digital e tátil (MATIAS, 1996).

Ratajski (1978) identificou várias tendências que influenciaram o pensamento científico voltado aos mapas da época: Teoria da Informação, Teoria da Modelização, Teoria da Metaciência, Teoria da Cognição e Semiologia. De acordo com os autores OLIVEIRA, 1978; NETO, 1984-1986; QUEIROZ, 2000; QUEIROZ, 2007 estas teorias apresentam as seguintes características:

- Teoria da Informação - foi desenvolvida como um sistema de base matemática, a partir dos conceitos de probabilidade e função logarítmica, para estudar os problemas decorrentes da transmissão de mensagens pelos canais físicos (telégrafo, rádio, etc.). Estabelece o esquema de informação (Emissor - Mensagem - Receptor) assim como os elementos que atuam nesse processo. Preocupa-se com as estruturas dos códigos sem levar em conta o significado dos signos. Esta teoria, desenvolvida para solucionar problemas técnicos da comunicação, influenciou a criação de uma nova abordagem na Cartografia denominada de Comunicação Cartográfica. Ratajski, que desenvolveu estudos para a elaboração de uma concepção teórica para a Cartografia contemporânea, denominada de Teoria da Informação, exerceu uma influência fundamental na definição do entendimento moderno da Cartografia.

- A Teoria da Modelização - emergiu no contexto da chamada revolução teoréticoquantitativa da Geografia, sendo que sua principal formulação teórica é a proposição e utilização dos modelos. Consideram-se os mapas como modelos que representam o conteúdo essencial da realidade. Board foi o primeiro a apresentar o mapa como 
modelo. A modelização cartográfica se apresenta como um método científico de investigação - o uso do mapa para descrição, análise e cognição científica dos fenômenos naturais ou sociais. Libault (1971) propõe um roteiro de investigação com base essencialmente cartográfica, o que consiste nos níveis compilatório, correlatório, semântico e normativo. O reflexo mais moderno dessa teoria está na introdução da tecnologia de Sistemas de Informação Geográficas - SIGs.

- Teoria da Metaciência - trata de um ramo do conhecimento cujas preocupações concentram-se nos aspectos teóricos formais da ciência e que, talvez por isso, ainda não recebeu o devido desenvolvimento na Cartografia. A principal contribuição dessa teoria refere-se ao surgimento do termo Metacartografia, entendida, de forma genérica, como a preocupação científica voltada para a determinação da essência e dos métodos da Cartografia.

- Teoria da Cognição - foi desenvolvida a partir da Psicologia e trouxe grandes avanços à Cartografia, tanto no processo de mapeamento, em que o cartógrafo passa a ter uma preocupação maior com as características do usuário, como no processo de leitura, em que o mapa passa a ser um instrumento para aquisição de novos conhecimentos sobre a realidade apresentada, evidenciando o caráter cognitivo tanto do cartográfo quanto do leitor para o processo de comunicação cartográfica.

- Semiologia Gráfica - Desenvolveu-se a partir de dificuldades encontradas na representação gráfica. Tem suas raízes no estruturalismo de Ferdinand de Saussure que criou a Semiologia Geral como ciência que estuda os signos. Os trabalhos que mais se destacam nessa corrente foram os de BERTIN (1973) e se fundamenta em uma ciência denominada "Semiótica", que tem por objeto de investigação todas as linguagens, em especial a dos signos. Bertin (1978) criou uma linguagem gráfica determinada por um sistema de signos gráficos com significado (conceito) e significante (conteúdo). Nesta concepção, o signo gráfico não deve ser tratado como polissêmico e a linguagem cartográfica amparada nas bases conceituais da Semiologia Gráfica é considerada uma linguagem universal, não convencional, e, portanto, monossêmica. Para Bertin, a monossemia não necessita de nenhum código. Seu principal trabalho na "semiologia do gráfico" é a elaboração de regras lógicas que conduzem à transcrição das relações entre elementos de dados e sua representação gráfica. 
Bertin identifica três relações - similaridade, ordem e proporcionalidade - que consistem nos significados da representação gráfica e são expressas pelas variáveis visuais: tamanho, valor, textura, cor, orientação e forma, que são os significantes. Essas variáveis visuais têm ainda três modos de implantação: pontual, linear e zonal, conforme a representação a seguir:

Quadro 1: Variáveis visuais proposta por Bertin

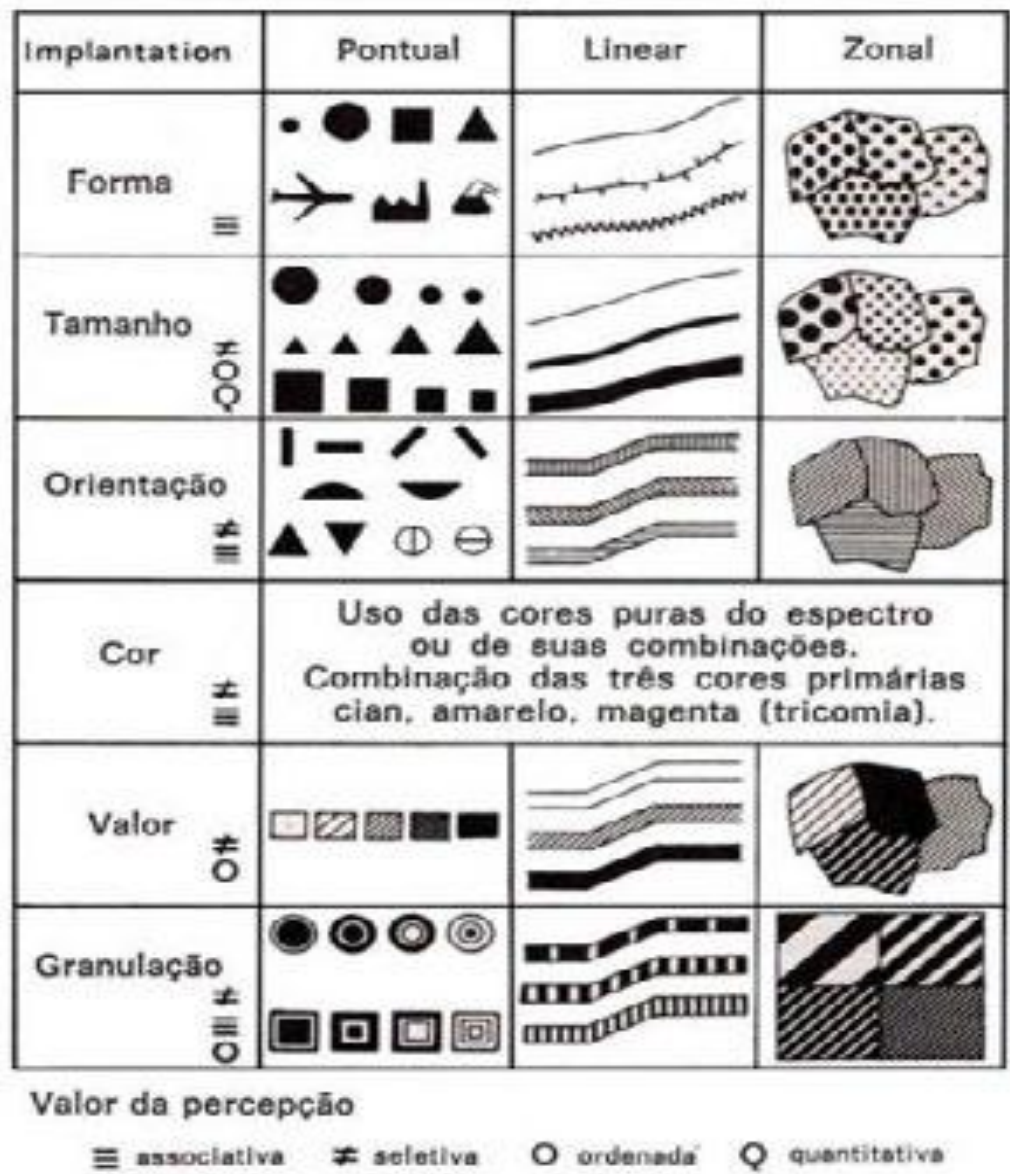

Fonte: JOLY. Fernand. A Cartografia. Campinas: Papirus, 1990, p. 13

Através dessas variáveis visuais, Bertin foi o primeiro a sistematizar as relações entre dados e sua representação gráfica, de modo a apresentar um ponto de partida na caracterização de uma linguagem cartográfica. Os códigos utilizados nos mapas são feitos de correlações, de significações, de significado. Bertin descobriu que também há uma semiologia gráfica para as representações e afirmou que "a representação gráfica faz parte do sistema de signos fundamentais que o homem construiu para reter, compreender e comunicar as observações necessárias à sua sobrevivência” (BERTIN, 1970, p. 1). 
A representação gráfica possui suas particularidades como uma linguagem destinada ao olho e como tal beneficia-se das propriedades de ubiquidade da percepção visual e obedece às suas leis. Constitui-se, assim, como um sistema de signos monossêmicos e se define como parte racional do mundo dos mapas. Ainda de acordo com BERTIN, a representação gráfica se destaca dos outros sistemas de signos pela dupla função de memória artificial e de instrumento de pesquisa e pode ser definida como o conjunto das observações e das regras que dirigem a utilização racional da representação gráfica. É racional porque se deduz das estruturas e das propriedades de percepção visual e se apoia em leis e regras de construção gráficas rigorosamente definidas. Fora dessas regras a construção gráfica perde sua utilidade e se transforma em uma imagem figurativa e o conteúdo informacional que se quer transmitir deixa de ser espontâneo.

A Representação Gráfica contempla o conjunto formado pelos diagramas, redes e cartas, constituindo, dentro do mundo das imagens, o sistema monossêmico. Por sua vez, o Grafismo contempla as imagens figurativas (desenhos, fotografias aéreas, etc.) e as imagens não-figurativas (fotografias comuns, etc.), formando o sistema polissêmico (QUEIROZ, 2007, p. 139-140; MATIAS, 1996, p.52-57; NETO. 1986, p. 16-22)

Visualização é outra teoria que tem se consolidado como a base conceitual para a Cartografia da Era Informacional. Segundo Taylor (1991, p. 4), visualização é o campo da computação gráfica interessado na exploração do poder analítico e comunicativo da interpretação visual, se configura como um campo interdisciplinar e depende de novas técnicas computacionais de análise e apresentação de dados e, portanto, é neste sentido precisa, exata e acurada.

De acordo com esse autor, a visualização é significativa porque pode desencadear o ato da cognição para identificar padrões e relações no contexto espacial, ao mesmo tempo em que alarga as possibilidades de análise, principalmente quando motivadas pelas metodologias científicas asseguradas pelas técnicas computacionais enriquecidas pela criação de novos produtos de multimídia. Isso tornou a cartografia mais interativa. Num sistema de visualização de informações cartográficas, os mapas são apresentados na tela do computador. Assim, as propriedades físicas de um mapa digital diferem de um mapa em papel, uma vez que na tela a imagem é formada por luzes (síntese aditiva), enquanto que no papel a separação é definida por pigmentos (síntese subtrativa). As novas tecnologias aumentam a possibilidade no uso das cores, na comunicação, possibilitando escolher e alterar as cores durante o uso de 
mapas eletrônicos, aumentando os recursos para a percepção visual (MATIAS, 1996, p.52-57; QUEIROZ, 2007, p. 139-140).

\subsection{A Cartografia Geográfica}

Desde a antiguidade clássica, atividades de registro e inventário dos lugares receberam a denominação de Geografia. Uma das obras de Claudio Ptolomeu, conjunto de oito volumes com saberes científicos, incluíam conhecimentos de geografia, como localização por coordenadas, técnica de projeção de mapas, de representação de superfícies curvas em um mapa plano. A Geografia de Ptolomeu contém também tabelas com listas de lugares e suas coordenadas geográficas, mapas e informações sobre países e seus habitantes. Posteriormente, estes saberes impulsionaram o desenvolvimento da cartografia.

Os povos antigos observavam os fenômenos naturais, os entendiam e sistematizavam esse conhecimento: inventaram um sistema de orientação olhando para o céu, descobriram a esfericidade da Terra observando o movimento aparente do sol e cunharam os pontos cardeais. A contínua observação dos astros sofisticou as técnicas de orientação, dando origem às coordenadas geográficas. O acúmulo desses conhecimentos contribuiu para a solução de uma questão geométrica: projetar uma superfície curva em um plano (FONSECA; OLIVA, p. 42-45). À medida que esses conhecimentos serviam para os avanços da cartografia, enquanto ciência, a Geografia também adquiria caráter científico ao apoderar-se dessas fontes. Os fenômenos adquiriram localização mais precisa com estudos mais exatos.

Os conhecimentos cartográficos são de interesse da Geografia, enquanto ciência que se interessa pelos fenômenos que ocorrem no espaço geográfico. Nos primórdios das civilizações humanas, os mapas eram instrumentos que consolidavam o conhecimento do território explorado e viabilizava a execução de tarefas corriqueiras do cotidiano. Nesta perspectiva, os mapas devem ser analisados sob o prisma das relações inerentes à condição humana que são estabelecidas na superfície terrestre.

Geografia, enquanto uma disciplina que se interessa pelo espaço habitado e transformado pelo ser humano, utiliza-se da Cartografia como uma metodologia para aprofundar essa discussão. A utilização de mapas na Geografia se justifica como instrumento legitimador do método, sua importância na Geografia reside na sua leitura, e não exclusivamente na sua elaboração técnica (GIRARDI, 2000, p. 41).

Pela Geografia, o espaço habitado pelo homem é analisado, compreendido, refletido e a representação dos fenômenos que ocorrem neste espaço é possível por meio de mapas, por 
isso, a cartografia está presente na formação profissional do geógrafo. O mapa atua como um recurso que permite uma visão única dos fenômenos que ocorrem no espaço geográfico.

Assim como na Geografia já não há espaço para as descrições áridas, os mapas integrados ao saber geográfico tampouco devem ser instrumentalizados sob um conjunto rígido de técnicas condicionado a uma métrica euclidiana. As transformações ocorridas no espaço terrestre, fruto das intervenções da sociedade capitalista, imprimiu no espaço geográfico uma nova dinâmica social e econômica que contribuíram para bruscas mudanças no meio natural e nas relações do ser humano com o espaço vivido, exigindo instrumentos mais dinâmicos de ler e interpretar os fenômenos geográficos. A consolidação e unificação dos conhecimentos geográficos residiram no aprimoramento das técnicas cartográficas, pois a representação gráfica se configurou como método tornando-se requisito da reflexão geográfica (MORAES, 2007, p. 52). A demanda da economia capitalista repercutia efetivamente no espaço geográfico e a cartografia se tornou instrumento de planejamento, análise e tomada de decisão frente às transformações que ocorriam de forma acelerada no espaço geográfico.

A Cartografia e a Geografia buscaram as mesmas fontes para consolidarem suas bases epistemológicas, pois os filósofos gregos tinham um objetivo comum: compreender os fenômenos do espaço geográfico. Nos primórdios da sistematização do conhecimento geográfico, a cartografia se configurava como instrumento de unidade dos diferentes aportes teóricos produzidos desde os tempos remotos da filosofia.

A localização de qualquer área ou fenômeno que ocorre na superfície terrestre pode ser representada num mapa, analisado por outros que apresentam interesse na realidade representada. Nesse fato reside a intrínseca relação da Geografia com a Cartografia. Ambas partem do mesmo princípio desde os períodos de especulações filosóficas até os tempos mais modernos nos quais consolidam suas bases epistemológicas e se fundamentam como ciência.

Em virtude da convergência entre os objetos de estudo da Cartografia e da Geografia, em muitas pesquisas, estas são indissociáveis, de forma que a primeira comunica a síntese, os resultados e uma visão integrada do trabalho do pesquisador. Sobre este aspecto, GEORGE (1986, p. 55) salienta que

[...] a representação cartográfica significa, sob formas várias, o ponto de partida e o ponto terminal do trabalho geográfico. [...] Sendo linguagem - o meio de expressão do geógrafo - o mapa apresenta, em diferentes etapas da aquisição do conhecimento, um balanço do que se encontra assimilado e integrado à imagem global do espaço. 
Muitos teóricos têm se dedicado a elucidar a importância do domínio das técnicas cartográficas e o resgate da utilização dos mapas como instrumento de análise do espaço geográfico. O mapa representa o documento de estudo por excelência. Antecede e conduz a pesquisa de campo. Sua leitura e sua explicação fomentam os problemas que deverão ser explanados pelo reconhecimento do terreno (GEORGE, 1986, p. 26).

A Geografia, em seu sentido literal, se configura como ciência das descrições. Nos dias atuais as descrições já não são tão fastidiosas como nos seus primórdios. Até mesmo os aspectos físicos são observados criticamente quando analisados em conjunto com as relações humanas e a forma de apropriação e exploração dos recursos naturais. As representações cartográficas também têm início na observação e na descrição. Nos dias atuais, os mapas, principal produto da cartografia e instrumento que também tradicionalmente identifica a Geografia, se desdobrou para estar além da representação topográfica e abarcar a multiplicidade de fenômenos que ocorrem na superfície terrestre e suas complexidades. Para Libault, (1967, p. 12)

a Geografia e a cartografia formam um todo indissociável. Podemos ter como certo que o progresso de cada uma ocasionará modificações na outra e vice e versa [...]. Abrindo uma janela sobre a noite da ignorância, o cartógrafo obriga o geógrafo a iluminar seus horizontes. Em outras palavras, quando o cartógrafo não puder responder à questão como, o geógrafo deve perguntar por quê?

Para Libault, a explicação dos fenômenos é a melhor característica da Geografia e os mapas expressam as diversas leituras que o pesquisador realiza da superfície terrestre. Apesar do seu caráter multidisciplinar e transversal, o geógrafo faz uso do mapa com mais conforto porque sua leitura transcende os limites da mera representação dos fenômenos e da técnica metodológica. Ele é capaz de enxergar as estruturas que originam os fenômenos representados, de questioná-lo criticamente, de propor soluções e de se antecipar aos problemas; O mapa ainda é dotado de um código de valor universal, o que contribui para que sua mensagem seja apreendida por todos de forma igual (Libault, 1967, p. 14).

A descrição das diferentes áreas da superfície terrestre, os levantamentos dos recursos naturais ocorriam dissociados dos fenômenos sociais. Acirrava-se, assim, a dicotomia humano e natureza, enquanto as relações entre ambos se tornavam complexas. O positivismo e os métodos que embasavam o conhecimento das ciências naturais não davam conta de explicar a complexidade das relações humanas e apropriação desigual dos recursos naturais. Os conhecimentos científicos adquiriram novos desafios frente à realidade socioeconômica e natural que se vislumbrava adiante. De acordo com (HARTSHORNE, 1978, p. 15) 
o objeto da Geografia é conhecer a Terra em seu caráter total, não em termos de categorias individuais de fenômenos - físicos, biológicos e humanos, dispostos em série - mas, em termos das combinações produzidas entre eles, porque tais combinações é que criam os diferentes aspectos físicos e humanos que a superfície da Terra apresentam.

Compreender criticamente as estruturas que desencadeavam esses processos configurava o desafio de novas posturas metodológicas que conduziam o conhecimento nesse período, e a Geografia não está alheia a esses processos, repensando seus métodos, aprimorando suas teorias, transformando o pensamento geográfico numa práxis que busca refletir sobre a realidade cotidiana do ser humano e sua relação com o espaço em que vive e com seus semelhantes.

É desse espaço e das diferentes relações que o ser humano estabelece sobre ele que a Geografia se debruça exaustivamente, na tentativa de compreender os conflitos, as contradições e as estruturas que geram a desigualdade e tornam os lugares diferentes. Sobre este aspecto (HARTSHORNE, 1978, p.16) afirma que

[...] no decurso da evolução da humanidade, o homem descobriu que seu mundo variava acentuadamente de lugar a lugar. Para satisfazer-lhe a curiosidade acerca de tais diferenças é que a Geografia se desenvolveu como matéria de interesse popular.

\subsection{A Cartografia Temática}

A Associação Cartográfica Internacional - ACI (1966) define cartografia como:

Conjunto de estudos e operações científicas, técnicas e artísticas que, tendo por base o resultado de observações diretas ou da análise da documentação, se voltam para a elaboração de mapas, cartas e outras formas de expressão e representação de objetos, fenômenos e ambientes físicos e socioeconômicos, bem como sua utilização.

O produto mais difundido desta ciência é o mapa. Sobre uma base cartográfica gerada a partir de diferentes procedimentos metodológicos é disposta uma coleção de dados ou informações, resultando numa representação gráfica de aspectos observados ou analisados de uma realidade perceptível. Essa realidade representada nos mapas é comunicada através de símbolos e outros recursos gráficos que compõem a linguagem cartográfica, cuja gramática intitulada de Semiologia Gráfica, sistematizada por J. Bertin, direciona metodologicamente até os dias atuais a construção de mapas temáticos em diferentes áreas do conhecimento ligadas às diversas teorias das formas e de sua representação e às teorias da informação.

A Cartografia se constitui em dois ramos complementares: a cartografia topográfica e a cartografia temática. A primeira se caracteriza pela delimitação com exatidão dos objetos circunscritos à face da terra, relacionando-se com a proposta da Geografia de descrição dos 
séculos XVII e XVIII, inventários exaustivos dos fenômenos do espaço da superfície terrestre (MARTINELLI, 1994, p. 62). A Cartografia Temática é um instrumento de expressão dos resultados adquiridos pela Geografia e pelas demais ciências que têm necessidade de se expressar na forma gráfica. ROSA (1996) ressalta que a cartografia temática se preocupa com a elaboração e o uso dos mapeamentos temáticos o que envolve a coleta, a análise, a interpretação e a representação das informações sobre uma carta base. É o conteúdo que vai ser representado no mapa que está em evidência, e não a precisão dos contornos ou da rede de paralelos e meridianos.

O mapa temático comunica saberes transdisciplinares, pois circula transversalmente pelas diferentes áreas do conhecimento, atende a diferentes públicos, sai da esfera acadêmica e atinge diversos veículos de informação. Democraticamente informa, orienta, direciona o planejamento e favorece a tomada de decisões.

De acordo com DUARTE (1991), as principais diferenças entre Cartografia Topográfica e Cartografia Temática podem ser sintetizadas no quadro abaixo:

Quadro 2: Características da Cartografia Topográfica e Cartografia Temática CARTOGRAFIA GERAL

Amplo e diversificado.

Grande diversidade

Elementos físicos ou a eles relacionados.

Em geral, os documentos podem ser usados por longo tempo.

Maior ênfase para dados qualitativos.

Não exige necessariamente conhecimentos específicos para compreensão dos documentos pelo leitor

Documentos executados por especialistas em Cartografia

Em geral, tem significado qualitativo
1. Quanto ao público que atende

2. Quanto aos propósitos

3. Quanto aos elementos representados

4. Quanto à durabilidade da informação

5. Quanto ao nível da informação

6. Quanto ao preparo

7. Quanto ao preparo do executor

8. Quanto ao significado das cores
CARTOGRAFIA TEMÁTICA

Especializado e reduzido.

Assuntos mais restritos.

Qualquer elemento, até mesmo os de natureza abstrata (ex. densidade demográfica).

Duração mais limitada, os dados são superados com mais rapidez

Dados quantitativos e qualitativos

Exige, em geral, conhecimentos especializados.
Documentos podem ser executados por pessoas não especialistas em Cartografia.

Significado tanto quantitativo como qualitativo

Fonte: DUARTE, P.A. Conceituação de Cartografia Temática. GEOSUL, n. 11, Ano VI, $1^{\circ}$ semestre 1991, p. 137 
Muitas produções cartográficas tiveram uma abordagem temática desde o período da consolidação da Cartografia enquanto ciência, mas foi Edmond Halley que lançou as bases metodológicas para esta nova abordagem representativa do espaço geográfico. Através do método Corocromático e Isarítimico, Halley apresentou dois trabalhos intitulados Mapas dos ventos alísios e monções (1686) e Mapa das declinações magnéticas (1701), ambos para o Oceano Atlântico.

O conhecimento efetivo do espaço geográfico se tornava imprescindível para estabelecer estratégias de ação no domínio de territórios específicos. A Cartografia, enquanto conhecimento que analisa a disposição dos elementos na superfície terrestre e que contribui para a análise de fenômenos que ocorrem no espaço geográfico, se torna importante instrumento para qualquer ação sobre este espaço. A partir desta necessidade é que as técnicas e instrumentos que permitem a exploração e o domínio do espaço vão sendo desenvolvidas e cada vez mais aperfeiçoadas na atualidade. Essas, que a princípio serviam aos interesses do Estado, atualmente, ainda que de forma limitada, encontram-se à disposição da sociedade civil, que pode utilizá-los como mecanismo de exploração do espaço em que vivem (MARTINELLI, 1999).

Por meio dos mapas temáticos, os fenômenos que ocorrem no espaço geográfico podem ser analisados de forma correlacionada. Com seus símbolos e cores, os diferentes fenômenos que ocorrem na superfície terrestre são representados, permitindo uma leitura ampla, atendendo a múltiplos objetivos e dialogando com as várias áreas do conhecimento.

Nesse contexto, os mapas temáticos devem ser analisados sem desprezar seu contexto social, respondendo questões que foram geradas numa escala temporal e espacial. Enquanto um instrumento de descoberta e de comunicação a serviço de um saber ou de uma ação, tem seus métodos na atualidade cada vez mais dinamizados pelo uso das tecnologias aplicadas ao desenvolvimento de pesquisas voltadas ao planejamento do manejo dos recursos naturais e na prevenção de problemas ambientais.

\subsection{Os cenários ambientais na Cartografia Temática}

Um dos desafios da contemporaneidade é a reconciliação entre homem e natureza. Durante séculos prevaleceu a herança do pensamento ocidental que institui o homem como dominador da natureza, culminando numa relação dicotômica e conflituosa. Os diferentes 
recursos naturais foram intensamente explorados para atender as necessidades ilimitadas de consumo do ser humano. Com os intensos sinais de esgotamento que a natureza tem apresentado, diferentes áreas do conhecimento têm se mobilizado para repensar essa relação e oferecer novos paradigmas à sociedade moderna.

A Cartografia não está alheia a esses novos anseios da sociedade e emerge dentro das abordagens temáticas com novos aportes metodológicos a fim de investigar, analisar e propor o planejamento através das representações gráficas para a problemática ambiental. Nesta perspectiva, a Cartografia Temática elabora cenários ambientais por meio da coleta de dados e de seu tratamento, pela apresentação de informações relacionadas às características físicas da natureza e considerando os aspectos socioeconômicos que influenciam diretamente nos processos bióticos e abióticos. A representação ambiental por meio da cartografia exige um conhecimento dos diferentes elementos naturais e as inter-relações que estes estabelecem tendo em vista sua caracterização multifacetada (MENEZES; NETO, 2007), exigindo do pesquisador uma visão holística, permitindo a compreensão e visualização da dinâmica do meio ambiente.

A Cartografia Temática se caracteriza por duas etapas distintas na elaboração de cenários ambientais: a cartografia analítica e a cartografia de síntese. Na primeira etapa, o pesquisador representa dados, frutos do levantamento físico e socioeconômico, tais como: uso e ocupação da terra, pedologia, geomorfologia, geologia, drenagem, população e economia (ZACHARIAS, 2008). A cartografia de síntese resulta em um mapa síntese que integra as informações, indicando áreas de potencialidades e de fragilidades da realidade espacial.

MARTINELLI (1994) destaca cinco contribuições metodológicas para a elaboração de cenários ambientais na Cartografia Temática: Paul Ozenda, Andre Journaux, Jean Tricart, Troppmair e Carlos Augusto de Figueiredo Monteiro. Paul Ozenda, em sua proposta metodológica, apresenta o objetivo de integrar todos os fatores ecológicos possíveis (físicos, biológicos, antrópicos) e de obter uma representação cartográfica sintética e única do ambiente.

O geógrafo Jean Tricart direcionou suas pesquisas às abordagens sistêmicas, evidenciando em seus documentos cartográficos (Carta Ecodinâmica) a intrínseca relação do meio ambiente e do homem. Troppmair também adota a metodologia geossistêmica em suas pesquisas realizando um mapeamento ambiental em macro, meso e micro-escala, utilizando imagens de satélite, definindo as categorias dos ecossistemas e geossistemas. Monteiro também buscou nas abordagens geossistêmicas representar através do mapa a qualidade 
ambiental e a relação sociedade e natureza. Em sua proposta metodológica, as condições ambientais são analisadas em três etapas: na primeira ocorre a análise da integração dos elementos naturais e antrópicos, na segunda o pesquisador associa os usos, recursos e problemas e na última etapa ocorre a síntese, que define as unidades homogêneas.

\subsection{Atributos dos mapas}

Constituídos por três elementos básicos: escala, projeção e simbologia, os mapas representam informações que partem de uma leitura ampla e aprofundada da realidade, por vezes, reduzida proporcionalmente para ser representada em uma superfície plana. Os elementos que compõem os mapas são indissociáveis e a sua compreensão é um pressuposto para que os pesquisadores consigam representar a realidade no papel e que o leitor a possa compreender.

Os símbolos apresentam, por meio de sinais, fenômenos selecionados que nos mapas comunicam informações representadas por meio da visualização. Neste sentido, a formação para a leitura de mapas tem início com a decodificação destes signos. O símbolo cartográfico pode ser entendido também como um sinal gráfico representando a existência de um objeto ou fenômeno de forma simplificada ou esquematizada, que é lembrada em um quadro de sinais ou legenda do mapa.

A postura metodológica visa responder questões mais amplas de forma ordenada (em que ordem), qualitativa (o quê), e quantitativa (quanto), proporcionando uma análise mais detalhada dos fenômenos que ocorrem no espaço geográfico (Joly, 1990). O caráter científico dos trabalhos cartográficos é definido pela escolha do método. Ao citar Cuenin (1972), MARTINELLI (2010, p.15) afirma que

este é condicionado pela natureza do fenômeno, pela característica dos seus componentes qualitativos ou quantitativos ordenados ou não, de sua ocorrência pontual, linear ou zonal, de sua distribuição localizada ou dispersa no espaço, com ou sem continuidade; enfim, a representação pode ser estática no espaço e no tempo ou ainda, dinâmica, expressando-se por variações no tempo ou movimentos no espaço.

As projeções associam - se às coordenadas na tentativa de amenizar os efeitos de distorção ao representar numa superfície plana a superfície terrestre. Em função disso, nenhum mapa plano contempla a uniformidade da representação. Para solucionar esta questão, um sistema que envolve cálculos matemáticos é executado sobre pontos da curvatura 
terrestre de forma que a Terra, ao ser representada num plano, sofra mínimas deformações. A projeção foi e é vista como o único meio aceitável para passar do globo ao plano da folha de papel. LIBAULT (1975, p. 105) define projeção como "uma correspondência matemática entre as coordenadas plano - retangulares da carta e as coordenadas esféricas da Terra". A classificação das projeções ocorre em função das diferentes metodologias utilizadas na representação da superfície terrestre e pode ser aplicada a uma diversidade de estudo. OLIVEIRA (1993) apresenta a seguinte proposta para classificar as projeções:

Quadro 3: Características das projeções cartográficas

\begin{tabular}{|c|c|c|}
\hline \multicolumn{3}{|c|}{ PROJEÇÕES CARTOGRÁFICAS } \\
\hline & CLASSIFICAÇÃO & CARACTERÍSTICAS \\
\hline \multirow{5}{*}{$\begin{array}{c}\text { TIPO DE } \\
\text { DEFORMAÇÃO }\end{array}$} & CONFORME OU SEMELHANTE & $\begin{array}{l}\text { Mantém a forma das áreas representadas sem } \\
\text { deformar os ângulos existentes no mapa. }\end{array}$ \\
\hline & EQUIDISTANTE & $\begin{array}{l}\text { Apresentam constância entre as distâncias } \\
\text { representadas, não possuem deformações lineares. }\end{array}$ \\
\hline & EQUIVALENTE & $\begin{array}{l}\text { Mantém constantes as dimensões relativas das áreas } \\
\text { representadas. }\end{array}$ \\
\hline & AZIMUTAIS OU ZENITAIS & $\begin{array}{l}\text { Preocupa-se com que os azimutes ou as direções de } \\
\text { todas as linhas vindas do ponto central da projeção } \\
\text { sejam iguais aos das linhas correspondentes na esfera } \\
\text { terrestre. }\end{array}$ \\
\hline & $\begin{array}{l}\text { AFILÁTICAS OU } \\
\text { ARBITRÁRIAS }\end{array}$ & $\begin{array}{l}\text { Não possuem nenhuma das propriedades anteriores, } \\
\text { ou seja, não conservam ângulos, distâncias nem } \\
\text { azimutes. }\end{array}$ \\
\hline \multirow{3}{*}{$\begin{array}{l}\text { LOCALIZAÇÃO } \\
\text { DO PONTO DE } \\
\text { VISTA }\end{array}$} & GNOMICA OU CENTRAL & O ponto de vista está situado no centro do elipsoide. \\
\hline & ESTEROGRÁFICA & $\begin{array}{l}\text { O ponto de vista está situado na extremidade } \\
\text { diametralmente oposta à superfície de projeção. }\end{array}$ \\
\hline & ORTOGRÁFICA & Quando o ponto de vista se situa no infinito. \\
\hline \multirow{3}{*}{$\begin{array}{l}\text { TIPO DE } \\
\text { SUPERFÍCIE }\end{array}$} & PLANA & A superfície de projeção é um plano. \\
\hline & CÔNICA & A superfície de projeção é um cone. \\
\hline & POLIÊDRICA & $\begin{array}{l}\text { Quando se utiliza vários planos de projeção que } \\
\text { reunidos formam um poliedro. }\end{array}$ \\
\hline
\end{tabular}




\begin{tabular}{|c|c|l|}
\hline \multirow{2}{*}{$\begin{array}{c}\text { POSIÇÃO DA } \\
\text { SUPERFÍCIE }\end{array}$} & EQUATORIAL & $\begin{array}{l}\text { Quando o centro da superfície situa-se no equador } \\
\text { terrestre. }\end{array}$ \\
\cline { 2 - 3 } PROJETADA & POLAR & Quando o centro do plano da projeção é um polo. \\
\cline { 2 - 3 } & TRANSVERSA & $\begin{array}{l}\text { Quando o eixo da superfície de projeção (um cilindro } \\
\text { ou um cone) se encontram perpendicularmente em } \\
\text { relação ao eixo de rotação da terra. }\end{array}$ \\
\cline { 2 - 3 } & OBLÍQUA & Quando está em qualquer outra posição. \\
\hline
\end{tabular}

Fonte: OLIVEIRA, C. Curso de cartografia moderna. $3^{\text {a }}$ edição, RJ: IBGE, 1993.

A escala de um mapa é a relação constante que existe entre as distâncias lineares medidas sobre o mapa e as distâncias lineares correspondentes, medidas sobre o terreno. De acordo com CASTRO (1997, p.123) é ela que confere a visibilidade ao fenômeno. Na geografia, este conceito está ligado ao raciocínio espacial e não ao matemático. A análise dos fenômenos geográficos pressupõe um nível de percepção dos mesmos e implica numa seleção apontando as escolhas e a aproximação do pesquisador perante o fenômeno a ser estudado.

Diante da complexidade das relações humanas cotidianamente influenciadas pelos sistemas econômicos e que repercutem diretamente no espaço geográfico, o conceito de escala suscita novas abordagens e a superação de paradigmas que foram cristalizados ao longo do período histórico, como a concepção que responde a uma visão geométrica de espaço. A pesquisa geográfica tem exigido cada vez mais um raciocínio espacial não mais apreendido pela lógica euclidiana e a escolha do nível de recorte da realidade espacial ultrapassa os limites do raciocínio simplificado da matemática.

A escala é um poderoso recurso metodológico à disposição da geografia que está associada à relação de proporção entre objetos (ou superfícies) e sua representação nos mapas. O homem não se movimenta num espaço com propriedades euclidianas e precisão matemática. O espaço humano é descontínuo, anisotrópico e tridimensional. Por conseguinte, mapear este espaço vivo e dinâmico, descrevê-lo e explicá-lo vêm se tornando um desafio para a Geografia e para a Cartografia. Esta nova concepção espacial implica em novas técnicas e métodos de representação e principalmente na utilização de geometrias não euclidianas para descrever as realidades espaciais. A Cartografia tem assumido cada vez mais em suas abordagens temáticas novas métricas capazes de abarcar as complexidades que envolvem as diferentes pesquisas em Geografia.

O termo escala é polissêmico e está presente em diferentes áreas do conhecimento, o que o torna complexo para apresentar uma definição rígida, porém não é possível subtrair de 
sua concepção o recorte da realidade percebida/concebida. As escalas deixam de ser uma noção cartográfica ou um conceito operacional que dá conta dos limites entre espaços diferenciados e fragmentados (como em um mosaico) e passa a ser um conceito integrado a uma teoria (a do desenvolvimento desigual) que procura dar coerência à produção do espaço em diferentes níveis, entendendo-o sempre como espaço organizado e hierarquizado. Smith reafirma que a escala geográfica é produzida socialmente, rompendo com uma tradição que toma o espaço como algo absoluto ou natural, submetido ao tempo e por isto autoevidente, não problemático (SMITH, 2002).

\subsection{Sistema de Informação Geográfica}

Os SIGs podem ser definidos como sistemas computacionais elaborados para armazenar e processar informações geográficas melhorando a eficiência e a efetividade do tratamento da informação de eventos e aspectos geográficos. Enquanto tecnologia, oferece suporte na tomada de decisão, enquanto ciência possui métodos específicos empenhados na descoberta de novos conhecimentos aplicados na resolução de problemas socioeconômicos e ambientais.

De acordo com LONGLEY et al. (2013, p.13) os SIGs podem ser definidos

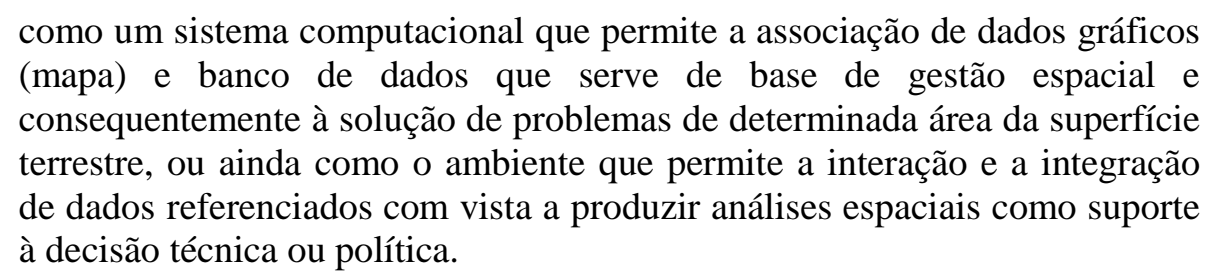

Os SIGs têm por objetivo primordial a análise espacial, favorecendo o planejamento de atividades diversas. Os primórdios do seu desenvolvimento estiveram atrelados aos interesses da dominação política e econômica dos governos ou das grandes corporações que atuavam em variados setores da sociedade, transpondo fronteiras transnacionais, e se ocupavam desde o conhecimento estratégico de localização de recursos naturais até a sua apropriação e exploração. Nas últimas décadas os SIGs se popularizaram e ultrapassaram os limites de uso científico, estratégico ou de planejamento, de forma que todo aquele que dispõe de um computador pode aprimorar seus conhecimentos sobre o espaço geográfico. Podemos usar dispositivos de baixo custo nos computadores pessoais, na internet ou em dispositivos de armazenamento de massa para manusear todo tipo de informação, independentemente de seu 
significado. Os dados digitais são simples de serem copiados, podendo ser transmitidos à velocidade da luz e armazenados em altas densidades em espaços bem exíguos, além de estarem menos sujeitos à deterioração que atinge o papel e outros meios físicos. Além do cruzamento de dados, o instrumento mais utilizado nessa empreitada são os mapas que respondem precisamente às questões "onde" e "como" (LONGLEY, et al. 2013, p. 79).

A eficiência dos SIGs pressupõe a existência de banco de dados consistentes e georreferenciados. Ao atribuir localização aos fenômenos, garantimos a sua espacialidade. Sem esta condição, a informação perde seu valor dentro do SIG, o que compromete a capacidade de mapear e sintetizar os diferentes tipos de informação sobre os mesmos locais, de mensurar distâncias e áreas.

Os sistemas de referência são imprescindíveis para os diferentes estudos que se realizam sobre a superfície terrestre, atendem a objetivos múltiplos e determinam os fluxos de mercadorias e pessoas nos dias atuais. Para este fim são estabelecidos sistemas de referência como endereço ou códigos postais. Os topônimos também são uma forma de georreferenciamento, embora menos complexos que outros sistemas, comunicam saberes relacionados com a história social, econômica e política do lugar ou características físicas explícitas na paisagem. A eficiência do sistema de georreferenciamento obedece aos requisitos de unicidade e persistência ao longo do tempo e deve ser compartilhada entre todas as pessoas que desejam trabalhar com informação geográfica. Considerando tais critérios, LONGLEY (et al., 2013, p. 124) defende que

Os mais poderosos sistemas de georreferenciamento são aqueles que fornecem potencial para uma resolução espacial muito detalhada, que permite o cálculo de distâncias entre dois locais e possibilitem outras formas de análise espacial.

De acordo com o autor, o sistema de Latitude e Longitude ou Sistema Geográfico de Coordenadas atende aos requisitos citados anteriormente, pois se baseiam na rotação da Terra sobre seu centro de massa, que define o eixo e o plano perpendicular ao eixo que dá origem ao Equador. Determinado o meridiano de referência, convencionou-se que as Longitudes variam de $180^{\circ}$ a Oeste até $180^{\circ}$ Leste do meridiano de referência. Esses valores, em projetos de SIG são entendidos como negativos a Oeste e positivos a Leste.

A definição de Latitude resulta dos estudos sobre a forma da Terra, caracterizada como geoide e "definida como sua superfície de igual gravidade formada pelos oceanos em repouso e pela extensão imaginária desta superfície sob os continentes" (LONGLEY (et al., 2013, p). A representação matemática da figura da Terra é o elipsoide de rotação que sofre 
achatamento nos polos. Em decorrência, o ângulo formado por esta linha com o plano do Equador é definido como Latitude e varia de $90^{\circ}$ Sul e $90^{\circ}$ Norte. Estas informações armazenadas em SIG também são reconhecidas como números negativos ao sul e positivos ao norte.

As coordenadas geográficas constituem o sistema mais abrangente de georreferenciamento e sustentam diferentes formas de análise, incluído cálculo de distâncias entre pontos sobre a superfície curva da Terra. Apesar disso, muitas tecnologias para trabalhar com dados geográficos são inerentemente planas, incluído papel e impressão, que evoluíram durante vários séculos antes do advento de dados geográficos digitais e SIG. As projeções associam-se às coordenadas na tentativa de amenizar os efeitos de distorção ao representar numa superfície plana a superfície terrestre. Em função disso, nenhum mapa plano contempla a uniformidade da representação, tão pouco o tamanho do pixel de qualquer matriz alcança ser perfeitamente constante. Nesta perspectiva, as projeções conservam duas propriedades de distorção: a de conformidade que preserva as formas e pequenas feições e a propriedade de equivalência que assegura que as áreas no mapa estejam na mesma proporção em relação às áreas medidas na superfície terrestre (LONGLEY et al., 2013, p.135-136).

O banco de dados é constituído de um conjunto integrado de dados sobre um determinado assunto. Esses dados podem ser fisicamente armazenados em arquivos ou programas especializados chamados de DBMS. Este software foi projetado para organizar o armazenamento e acesso de dados de forma eficiente e eficaz, garantindo sua longevidade e integridade, sobretudo quando o banco de dados é mais complexo e com número elevado de usuários.

O sistema DBMS pode ser classificado em três tipos, de acordo com o modo como organizam, armazenam e manipulam os dados: relacional, objeto e objeto-relacional. O banco de dados do tipo RELACIONAL é composto por um conjunto de tabelas, cada uma correspondente à uma lista bidimensional de registro, contendo atributos sobre o objeto de estudo. O sistema de gerenciamento de banco de dados do tipo OBJETO pode armazenar e oferecer ferramentas de consulta orientadas a objetos. O sistema OBJETO-RELACIONAL possui recursos adicionais como dados que descrevem o objeto (seus atributos como cor, tamanho e idade) e o comportamento que determina o que um objeto faz (métodos ou funções de objetos, como instruções de desenho, interfaces de consulta e algorítmicos de interpolação). Estes dados podem ser geridos e armazenados em conjunto com um todo integrado (LONGLEY et al. 2013 p. 254-255). 
Os dados geográficos que resultam em representações são constituídos de fatos sobre o mundo geográfico. Um Datum associa-se a um lugar em um período de tempo com propriedades descritivas ou atributos que podem ser de ordem físicos ou ambientais, socioeconômicos, podem identificar lugares, mensurar algo em um lugar e no tempo ou classificar em categorias os fenômenos estudados (exemplo: classes de uso do solo, diferenciando entre usos agrícolas, industriais ou residenciais). Em SIG, os atributos se classificam em nominais, ordinais, intervalo, razão e cíclicos conforme a tabela abaixo:

Quadro 4: Atributos dos SIGs

\begin{tabular}{|c|c|c|c|}
\hline Escala & Características & Exemplos & Operações possíveis \\
\hline Nominal & Descrição & $\begin{array}{c}\text { Tipo de solo, } \\
\text { vegetação, uso do } \\
\text { solo }\end{array}$ & Seleção, Comparação \\
\hline Ordinal & Ordem & $\begin{array}{c}\text { Classes de } \\
\text { declividade, aptidão } \\
\text { de uso }\end{array}$ & $\begin{array}{c}\text { Mediana, máximo, } \\
\text { mínimo }\end{array}$ \\
\hline Intervalo & Distância & Altimetria & Diferença, Soma \\
\hline Razão & Valores absolutos & $\begin{array}{c}\text { Renda, população, } \\
\text { taxa de natalidade }\end{array}$ & Operações \\
& Aritméticas \\
\hline Cíclico & Direcionais & $\begin{array}{c}\text { Direção de fluxos em } \\
\text { mapas, direção em } \\
\text { uma bússola, } \\
\text { longitude ou mês do } \\
\text { ano }\end{array}$ & Cálculo de média \\
\hline & \begin{tabular}{c} 
\\
\hline
\end{tabular} & & \\
\hline
\end{tabular}

Fonte: Adaptado de CÂMARA, 2005; LONGLEY et al. 2013

A representação do espaço geográfico envolve a compreensão de dois esquemas conceituais: objetos discretos e campos contínuos. Na visão de Objetos, a realidade é vista como uma superfície ocupada por entidades identificáveis e cada porção (x e y) do espaço poderá estar ou não ocupados. Os objetos se distinguem por suas dimensões, identificáveis através das categorias de pontos, linhas ou áreas. Os dados espaciais possuem características próprias, cuja percepção por parte do usuário definirá formas de percepção. Os dados da realidade real ao serem transpostos para o mundo virtual seguem padrões conceituais, utilizando modelos vinculados à concepção de espaço do indivíduo, que resulta numa visão 
abstrata e simplificada da realidade. Nesta perspectiva cada entidade tem suas propriedades e ocupa um determinado lugar no espaço. A realidade é modelada como um grande espaço, onde entidades estão distribuídas sem que necessariamente todas as posições no espaço estejam ocupadas.

$\mathrm{Na}$ visão de campos, o mundo real é visto como uma superfície contínua, não existindo nenhuma posição no espaço geográfico que não esteja associada a algum valor correspondente à variável representada. De forma geral, os fenômenos naturais, físicos ou biológicos são representados por variáveis contínuas como, por exemplo, temperatura, pressão atmosférica e tipo de solo. Na visão de campos, a realidade é modelada por variáveis que possuem uma distribuição continua no espaço (CÂMARA, 2005; LONGLEY et al. 2013).

Os fenômenos geográficos podem ser codificados em base de dados através de dois métodos: matricial e vetorial. Ambos podem codificar campos e objetos, mas de forma geral associa - se matrizes a campos e vetores a objetos. Os dados matriciais são obtidos através de satélites que capturam as informações nesse formato e posteriormente são disponibilizados e analisados em diferentes projetos de SIG. Em uma representação matricial, o espaço é dividido em uma malha retangular de células também chamada de pixels. A representação matricial supõe que o espaço pode ser tratado como uma superfície plana, onde cada célula está associada a uma porção do terreno. Neste formato, tem-se uma matriz de células, às quais estão associados valores que permitem reconhecer os objetos sob a forma de imagem digital. Cada uma das células é endereçável por um par de coordenadas (linha, coluna) associado a um par de coordenada espacial (x e y) ou latitude e longitude. Os pixels se associam a valores utilizados para definir uma cor para apresentação na tela ou para impressão e correspondem a um fragmento do mundo real (CÂMARA, 2005; LONGLEY et al. 2013).

No modelo vetorial, a localização e aparência gráfica de cada objeto são representados por um ou mais pares de coordenadas. Isso não é exclusividade de SIG. Outros sistemas gráficos também utilizam representação vetorial, mas os SIGs são os que apresentam maior sofisticação na representação em função do volume de dados que é processado. A representação vetorial considera três elementos gráficos: ponto, linha poligonal e área (CÂMARA, 2005; LONGLEY et al. 2013).

\subsection{O papel do SIG na Geografia}


A evolução do pensamento geográfico é permeada pelo debate paradigmático entre Geografia Tradicional (ideográfica) e a Nova Geografia (Nomotética). O primeiro paradigma se caracteriza pela observação, pela leitura dos fenômenos inscritos na paisagem e sua descrição ocorre de maneira pormenorizada a fim de correlacionar e estabelecer sínteses da superfície terrestre. Na Nova Geografia ocorreu uso de modelos, classificação e generalização. O surgimento dessa nova perspectiva de abordagem está integrado na transformação profunda provocada pela Segunda Guerra Mundial nos setores científicos, tecnológico, social e econômico. Esta transformação, abrangendo o aspecto filosófico e metodológico, foi denominada de Revolução Quantitativa e Teorética da Geografia (CHRISTOFOLETTI, 1982, p. 16-18).

A Nova Geografia visava maior rigor na aplicação da metodologia científica, onde o pressuposto metodológico estava pautado na observação empírica e no uso de técnicas matemáticas e estatísticas para realizar a coleta de dados e analisar a distribuição espacial dos fenômenos. A Nova Geografia também se valeu das abordagens sistêmicas para ampliar as perspectivas de análise do espaço geográfico tendo em vista uma interpretação mais complexa da organização do sistema espacial, observando sua interação. Os estudos geográficos nesse período pautaram-se também na construção de modelos, enquanto estruturação sequencial de ideias relacionadas com o funcionamento do sistema. Por meio do modelo é possível expressar as relações entre os diversos componentes (CHRISTOFOLETTI, 1982, p. 19).

A inserção dos SIGs na Geografia ocorre entre as décadas de 1950 e 1960, quando a tecnologia se torna aliada no estudo do espaço geográfico. Em seus primórdios, os SIGs estavam a serviço dos órgãos governamentais, favorecendo o planejamento e o controle do território. Seu atrativo estava relacionado com a capacidade de processar grande quantidade de informação e otimização do tempo. O uso das tecnologias consolidou os paradigmas da Nova Geografia caracterizada como geografia aplicada e de modelos, que adota o positivismo lógico e a linguagem matemática como garantia da relação lógica com a realidade, marcada pela objetividade técnica-analítica e neutralidade política (GOMES, 1995, 253). A valorização do SIG na Geografia advém do seu aspecto conciliador entre o geral e o específico atribuindo valor prático a ambos. De acordo com LONGLEY (et al., 2013, p. 15)

O Software de um sig captura e implementa o conhecimento geral, enquanto o banco de dados de um Sig apresenta a informação específica. Neste sentido, um sig resolve o antigo debate entre os campos nomotéticos e ideográficos acomodando ambos. 
A utilização dos SIGs em pesquisas geográficas suscitam muitas questões, principalmente sobre a abordagem dos aspectos socioeconômicos e sua representação através das técnicas cartográficas, dos modelos e diagnósticos, tendo em vista que os SIGs desde sua origem estão a serviço do aparelho do Estado, legitimando ideologias ou garantindo a posse e o controle do território, porém com os avanços na informática e a disponibilização de software, imagens de satélites e dados que permitem maior conhecimento sobre o espaço geográfico, a análise espacial transpôs os muros dos órgãos de planejamento e democratizou o acesso, dinamizando a ciência cartográfica e demais áreas do conhecimento que se empenha na investigação dos fenômenos que ocorrem na superfície terrestre.

Os projetos de SIG resultam em diversas representações que se destinam a aprofundar a análise dos fenômenos que ocorrem no espaço geográfico, mas é na cartografia que se concretiza em plenitude os objetivos do SIG. Através do mapa as operações de SIG comunicam de maneira eficaz os resultados do trabalho do pesquisador e atingem um público mais amplo, expressa os conhecimentos transdisciplinares e favorecem a tomada de decisão em diversos setores da sociedade. De acordo com LONGLEY (et al., 2013, p. 31)

O mapeamento atualmente deve ser capaz de comunicar uma ampla variedade de mensagem e simular a maior variedade de cenários possíveis [...]. A tecnologia levou ao desenvolvimento de uma enorme gama de dispositivos para trazer o mapeamento para uma maior gama de usuários no mais amplo espectro de ambientes e decisão.

Essa premissa tem contribuído para um debate envolvendo a ciência geográfica nos dias atuais e sua relação com a cartografia. A análise espacial na perspectiva geográfica, que tem como aliado os SIGs na representação cartográfica, pode ser comprometida quando a manipulação de dados não é realizada de maneira crítica e observando as diferentes relações entre os fenômenos econômicos, sociais, culturais e políticos que permeiam a realidade geográfica, superando a lógica do positivismo que contribui para uma análise estanque, isolada e fracionada.

A Geografia em sua essência produz conhecimentos complexos sobre o espaço vivenciado pelo ser humano, pode oferecer respostas às questões que envolvem as contradições do sistema econômico vigente e que determina as relações nos dias atuais e os SIGs, enquanto instrumento capaz de reunir em um único software um volume considerável de informações de diferentes naturezas, assume, ao expressar através dos mapas, o papel de integrador de conhecimentos, possui caráter multidisciplinar e favorece a análise mais ampla da realidade. 


\subsection{Sensoriamento Remoto}

O Sensoriamento Remoto tem sua história de desenvolvimento atrelada às práticas de controle dos diferentes territórios por parte dos militares. O impulso para o desenvolvimento de tecnologias sofisticadas que permitissem o conhecimento efetivo da superfície terrestre teve seu auge no período entre guerras e somente após a Guerra Fria os produtos provenientes das técnicas de Sensoriamento Remoto saíram dos departamentos de defesa e chegaram à sociedade civil. O termo em questão foi cunhado em 1960, em artigo não publicado, pelo grupo Office of Naval Research (ONR), que conhecera o uso da fotointerpretação aérea na Segunda Guerra Mundial e acompanhara a inauguração da era espacial com o lançamento do SPUTNIK (1957 pela URSS) e do EXPLORER 1 (1958 pelo EUA). A prática de registro e coleta de dados por sensoriamento remoto, no entanto, data de 1858, quando a primeira fotografia a partir de uma plataforma aérea foi emitida (JENSEN, 2009 p. 3-9). Os excelentes programas espaciais impulsionaram as pesquisas para a construção de novos equipamentos capazes de fotografar a Terra com capacidade de recobrir a superfície terrestre sucessivas vezes e de transmitir e armazenar os dados coletados.

Fruto de conhecimentos multidisciplinares como a matemática, física, química, ciências da terra e computação, o Sensoriamento Remoto serve a saberes transdisciplinares, sobretudo às ciências que se dedicam ao estudo da superfície terrestre, associada aos SIGs, favorece a compreensão de fenômenos inter-relacionados que se processam no espaço geográfico. A evolução das técnicas de Sensoriamento Remoto e as diferentes aplicações permitiram formular diferentes conceitos que são considerados apropriados dentro do contexto. JENSEN (2009, p. 4) apresenta uma definição abrangente que permite compreender os métodos e os instrumentos utilizados nas técnicas de Sensoriamento Remoto.

Sensoriamento Remoto é o registro da informação das regiões do ultravioleta, visível, infravermelho e micro-ondas do espectro eletromagnético, sem contato, por meio de instrumentos tais como câmeras, escâneres, lasers, dispositivos lineares e/ou matriciais localizados em plataformas tais como aeronaves ou satélites, e a análise da informação adquirida por meio visual ou processamento de imagens.

De forma geral os objetos ou áreas geográficas emanam energia eletromagnética que são captadas e registradas pelos sofisticados sensores eletrônicos, instalados em satélites artificiais orbitais ou em plataformas terrestres, aéreas (balões, helicópteros e aviões). A radiação eletromagnética (REM) estabelece a comunicação entre o sensor e o fenômeno remoto que ao ser medida é convertida em informação técnica visual ou técnicas de 
processamento digital de imagem. Pode-se considerar que a detecção das interações entre radiação eletromagnética e os objetos da superfície terrestre é o princípio básico de toda tecnologia do sensoriamento remoto.

O fluxo de energia eletromagnética ao atingir um objeto (energia incidente) sofre interações com o material que o compõe, sendo parcialmente refletido, absorvido e transmitido pelo objeto. A absorção, reflexão e transmissão da energia incidente pode ser total ou parcial, guardando sempre o princípio de conservação de energia. A capacidade de um objeto absorver, refletir e transmitir a radiação eletromagnética é denominada, respectivamente, de absortância, reflectância e transmitância.

As imagens de sensoriamento remoto resultam da indissociabilidade entre onda (comprimento) e energia (intensidade). Essa interação ocorre em nível macroscópico quando está em evidência a intensidade com que um objeto reflete a radiação eletromagnética em razão do tamanho da onda e a textura da superfície do objeto. A textura representa a rugosidade topográfica da superfície. Ela pode ser estimada pelas variações verticais de altura da superfície de um material e se mostra muito eficiente para explicar as diferenças observadas nas imagens entre as diversas formas de relevo, os tipos de dosséis da vegetação, ou da superfície lisa de um corpo d'água calmo ou com ondas revoltas, ou seja, se relaciona com as propriedades texturais dos objetos.

A interação microscópica ocorre quando os átomos e moléculas dependem da constituição química (atômica/molecular) do material. Materiais de diferentes composições, ou seja, com diferentes constituições de elementos químicos de átomos e moléculas, têm absorções e reflectâncias diferentes, resultando nas imagens em diferentes tons de cinza. Sendo assim, para se discriminar ou diferenciar nas imagens de sensoriamento remoto um objeto do outro, como uma ardósia de um granito, deve-se ter imagens nos comprimentos de onda de alta energia, que possam interagir com os minerais constituintes. E para que possamos ver as diferenças das duas rochas, em função tão somente de suas texturas (formas de relevo), é aconselhável ter imagens nos grandes comprimentos de onda, onde a textura da superfície das rochas é que comanda as intensidades de reflectâncias (MENEZES; ALMEIDA, 2012, p. 6- 18).

O espectro eletromagnético é uma divisão didática da distribuição da radiação eletromagnética pelas distintas regiões, organizado de acordo com o comprimento e frequência de onda. Ao atingir o objeto, a energia eletromagnética inicialmente absorvida causa reações nos seus elétrons, os quais ficam em condição de excitação e retorna ao estado 
original. Durante este processo é gerado um quantum, ou fóton, de energia que é registrado pelo sistema sensor, o que permite a geração da imagem (ABREU e COUTINHO, 2014, p. 175). O comprimento de onda da REM é percebido através do estudo do espectro eletromagnético. Apesar de a faixa de comprimento de onda da radiação eletromagnética (REM) ser praticamente ilimitada, o espectro eletromagnético foi dividido pelo homem em intervalos de comprimentos de onda com base nos mecanismos físicos geradores da energia eletromagnética e nos mecanismos físicos de sua detecção (MENEZES; ALMEIDA, 2012, p. 19).

A nomenclatura de cada um dos intervalos foi feita em função do uso que o homem encontrou para as suas aplicações. As imagens não são definidas num específico comprimento de onda, mas abrangendo pequenos intervalos, chamados de bandas espectrais. A tabela abaixo apresenta os principais intervalos espectrais e suas características:

Quadro 5: Principais intervalos espectrais e suas características

\begin{tabular}{|c|c|c|}
\hline Intervalos espectrais & Características & Aplicação em SM \\
\hline Visível & $\begin{array}{l}\text { Região do espectro solar com } \\
\text { a mais alta intensidade de } \\
\text { fluxo radiante, transparente, } \\
\text { dessa faixa espectral é o alto } \\
\text { espalhamento da radiação } \\
\text { solar incidente pelos gases } \\
\text { atmosféricos, que pode } \\
\text { reduzir o contraste da } \\
\text { reflectância dos alvos } \\
\text { terrestres }\end{array}$ & $\begin{array}{l}\text { Interação com os minerais e } \\
\text { que dá origem às suas cores e } \\
\text { com os pigmentos da } \\
\text { vegetação. }\end{array}$ \\
\hline Infravermelho próximo & $\begin{array}{l}\text { Região do espectro solar } \\
\text { onde a atmosfera também é } \\
\text { bastante transparente, mas } \\
\text { ocorrem algumas bandas de } \\
\text { absorções. Intervalo onde } \\
\text { ocorrem importantes } \\
\text { interações da REM com os } \\
\text { níveis de energia eletrônica } \\
\text { dos átomos. }\end{array}$ & $\begin{array}{l}\text { Diagnósticas para identificar } \\
\text { a natureza de vários tipos de } \\
\text { rochas, principalmente as de } \\
\text { composição mineral com } \\
\text { metais de transição (Fe, Ni, } \\
\text { Cr, Mn...). }\end{array}$ \\
\hline Infravermelho médio & $\begin{array}{l}\text { Região onde o Sol e a Terra } \\
\text { não emitem quantidades } \\
\text { suficientes de energia que } \\
\text { possam ser detectadas pelos } \\
\text { sensores. Somente alvos com }\end{array}$ & $\begin{array}{c}\text { Sensores meteorológicos ou } \\
\text { atmosféricos. }\end{array}$ \\
\hline
\end{tabular}




\begin{tabular}{|c|c|c|}
\hline & $\begin{array}{l}\text { elevadas temperaturas, como } \\
\text { vulcões e incêndios, podem } \\
\text { ser detectados, pois agem } \\
\text { como fontes próprias de } \\
\text { emissão de radiação }\end{array}$ & \\
\hline Infravermelho termal & $\begin{array}{l}\text { É conhecido como a região } \\
\text { termal, devido à radiação } \\
\text { emitida pelos objetos } \\
\text { terrestres em função das suas } \\
\text { temperaturas de superfícies. }\end{array}$ & $\begin{array}{c}\text { Ótima faixa espectral para } \\
\text { detecção de quartzo de veios } \\
\text { nas rochas. }\end{array}$ \\
\hline Micro-ondas & $\begin{array}{l}\text { Região de uso de sensores } \\
\text { ativos (radar), que utilizam } \\
\text { fontes artificiais para a } \\
\text { geração da REM. Por causa } \\
\text { do tamanho do comprimento } \\
\text { da onda, o radar tem a } \\
\text { habilidade de operar em } \\
\text { condições atmosféricas } \\
\text { adversas, com coberturas de } \\
\text { nuvens ou chuvas, e pode } \\
\text { operar tanto de dia como à } \\
\text { noite. }\end{array}$ & $\begin{array}{c}\text { A geologia estrutural e } \\
\text { mapeamento geológico, } \\
\text { porque a interação das } \\
\text { micro-ondas com as rochas é } \\
\text { controlada pelas texturas de } \\
\text { relevo. }\end{array}$ \\
\hline
\end{tabular}

Fonte: MENEZES, P. R.; ALMEIDA, T. (org) Introdução ao processamento de imagens de sensoriamento remoto. Brasília: UNB/CNPQ, 2012, p. 20)

Os objetos interagem de maneira diferenciada espectralmente com a energia eletromagnética incidente, pois os objetos apresentam diferentes propriedades físico-químicas e biológicas. Estas diferentes interações é que possibilitam a distinção e o reconhecimento dos diversos objetos terrestres sensoriados remotamente, pois são reconhecidos devido a variação da porcentagem de energia refletida em cada comprimento de onda.

As melhores regiões de comprimento de onda para discriminar terra de água pura são o infravermelho próximo e o infravermelho médio. Nessas regiões os corpos d'água aparecem muito escuro, mesmo pretos, porque as superfícies aquáticas absorvem praticamente todo o fluxo radiante incidente, especialmente quando a água é profunda e pura ou sem presença de sedimentos em suspensão ou matéria orgânica. O oposto ocorre nas coberturas da terra composta por vegetação e solo exposto, pois elas refletem quantidades significantes de energia no infravermelho próximo e médio, aparecendo relativamente claras nas imagens obtidas em bandas do infravermelho próximo e médio. Quando existem compostos orgânicos 
e inorgânicos na coluna d'água, especialmente junto à superfície no infravermelho próximo, a água aparece tão clara quanto algumas feições do terreno próximo ao delta (JENSEN, 2009).

O sensoriamento pode prover informações sobre a composição química das rochas e de minerais da superfície terrestre que não estejam completamente recobertos por vegetação densa. Grande parte das informações usadas por pedólogos para mapear séries de solos, são observados de forma direta no campo. As características de reflectância espectral dos solos ocorrem em função de alguns fatores que inclui textura do solo, umidades, conteúdo de matéria orgânica e óxido de ferro, salinidade e rugosidade superficial. Solos argilosos, densos e compactados retêm mais água, enquanto que solos arenosos drenam a água mais rapidamente que os solos argilosos. Nesta perspectiva, solos mais úmidos absorvem mais a energia incidente, o oposto ocorre com os solos secos e arenosos. A quantidade de energia refletida no verde, vermelho, no infravermelho próximo e médio é drasticamente reduzida à medida que a umidade do solo aumenta. A quantidade de matéria orgânica também tem impacto nas características de reflectância espectral dos solos expostos. De forma geral, quanto maior a quantidade de matéria orgânica, maior será a absorção de energia incidente e menor a reflectância espectral. O Sensoriamento Remoto também oferece suporte para extrair informações sobre a salinidade. A reflectância geralmente aumenta com a elevada concentração de sais. Os solos afetados por sais mostram resposta espectral relativamente maior nas regiões do visível e do infravermelho próximo que em solos não salinos, sendo que os solos fortemente salino-sódicos exibem respostas espectrais maiores que os solos moderadamente salino-sódicos (DALMOLIN et al, 2005).

\subsection{Características dos principais sistemas sensores orbitais em operação}

O Sensoriamento remoto aplicado aos estudos geotemáticos envolve duas questões fundamentais: resolução da imagem (este conceito é adotado para identificar as características dos sistemas imageadores em geral) e a escala de representação dos objetos ou fenômenos geográficos. São quatro os tipos de resolução ou formas de medidas das imagens obtidas por sensoriamento remoto: resolução espacial, espectral, radiométrica e temporal. Elas atuam em conjunto num processo interativo e elucidam questões referentes a todos os tipos de sensores

imageadores, independentes da faixa espectral em que operam, à exceção do RADAR. Como segue:

Resolução Espacial ou Geométrica: trata diretamente do tamanho do pixel em unidade de metro. Toda área imageada no limite interno de um pixel terá uma única cor, ou seja, se a 
resolução espacial é de 30m x 30m, este pixel será representado de acordo com o alvo predominante em uma área de $900 \mathrm{~m}^{2}$. Quanto menor a área quadrada do pixel, maior é a resolução espacial da imagem, consequentemente, melhor será a definição dos alvos.

Resolução Espectral: indica a região de origem da imagem no espectro eletromagnético, ou seja, o tipo de onda registrada. Esta resolução é adotada para a identificação de distintos alvos, pautando-se no princípio de que certos alvos podem ser mais bem definidos que outros em bandas de imagens.

Resolução Radiométrica: cada banda é gerada a partir de determinado intervalo, frequência de onda, cuja redução de amplitude ou centralização do intervalo resultará em melhor resolução espectral das imagens.

Resolução Temporal: trata do tempo de cobertura, em dias, que o sensor leva para passar sobre uma mesma área e, ainda, da largura da faixa de imageamento. É uma informação de grande importância, principalmente para análises multitemporais (ABREU; COUTINHO, 2014, p. 180).

As imagens provenientes do Sensoriamento Remoto são obtidas por câmeras fotográficas aéreas e por satélites que orbitam a Terra. As fotografias aéreas registram alvos por meio de detecção do fluxo de radiação eletromagnética refletida pelas superfícies dos objetos terrestres. São consideradas como os primeiros produtos do sensoriamento remoto, e mesmo com o advento dos satélites, ainda são muito utilizadas em pesquisas depois que passou a adotar novas técnicas, como a incorporação da banda infravermelha e do sistema digital, muito importantes em estudos de qualquer natureza. Recorrem-se às fotografias aéreas quando se precisa de mais detalhes, observa - se, assim, uma complementaridade de funções entre fotos aéreas e imagens de satélites.

O desenvolvimento dos sensores não fotográficos, denominados de imageadores multiespectrais, dinamizou os métodos do Sensoriamento Remoto, sua eficiência está pautada nos seguintes aspectos: os dados são em formato digital, podem ser operados de plataformas espaciais por meio de satélites, gerando sucessivas imagens ao longo de vários anos; obtenção de imagens num amplo intervalo de comprimento de onda, com dezenas a centenas de bandas espectrais. As imagens obtidas por imageadores a bordo de satélites possibilitam o imageamento global da terra, em curto período de tempo, favorecendo o monitoramento preciso de mudanças ambientais e sua utilização transcende as aplicações temáticas das ciências da terra. 
Atualmente circulam no espaço dezenas de sensores orbitais imageando a superfície terrestre em todas as faixas espectrais possíveis, com mais variados parâmetros de resolução espacial e temporal. De um lado há os sensores hiperespectrais com centenas de bandas espectrais (centenas de imagens) e do outro, há os sensores de alta resolução espacial capaz de detectar os objetos na superfície terrestre menor que $50 \mathrm{~cm}$. E para atravessar a opacidade das nuvens, há os sensores de RADAR com suas fontes artificiais de radiação eletromagnética.

\subsubsection{Características do sistema radar}

O sistema RADAR é considerado uma alternativa ao estudo da vegetação, devido às limitações dos sensores ópticos, como a dependência de fonte externa de energia (luz solar), a perda da qualidade da imagem por ocorrências atmosféricas, a cobertura de nuvens, etc. As imagens de radar apresentam uma perda de informação e de detalhes, o que leva à necessidade de tratamento diferenciado para estudos com dados de radar, (filtros, segmentadores, classificadores) a fim de melhorar sua qualidade, principalmente a resolução espacial e espectral, com o objetivo de apresentar com maior definição os alvos imageados.

Os sistemas ativos não são dependentes da energia eletromagnética do sol ou das propriedades termais da Terra. Possuem a propriedade de gerar sua própria energia eletromagnética que: 1) é transmitida do sensor para a superfície do terreno e é pouco afetada pela atmosfera; 2) interage com o terreno produzindo um retroespalhamento da energia; 3) é registrada pelo receptor do sensor remoto.

Os sistemas de Sensoriamento Remoto ativos mais amplamente utilizados são: microondas ativos RADAR, que são baseados na transmissão de micro-ondas de comprimento de ondas mais longas através da atmosfera e na detecção da qualidade de energia retroespalhada pela superfície do terreno; o sistema LIDAR, que se baseia na transmissão de energia de comprimentos de onda relativamente curtos da luz laser através da atmosfera e na detecção da qualidade de energia retroespalhada pela superfície do terreno e o sistema SONAR, baseado na transmissão de ondas sonoras através da coluna de água e na detecção da quantidade de energia retro-espalhada pelo fundo, ou por objetos no interior da coluna de água. Os sistemas LIDAR E SONAR são úteis ao mapeamento topográfico e batimétrico respectivamente (JENSEN 2009, p. 293).

O sistema de RADAR é o mais amplamente utilizado para estudos dos recursos naturais da Terra. Seu desenvolvimento também compôs os aparatos tecnológicos de guerra. As imagens de RADAR obtidas de aeronaves ou satélites foram largamente utilizadas durante 
a Segunda Guerra Mundial, porém o acesso era restrito. A NASA lançou diversos radares de cobertura sintética (SAR), a exemplo do SEASATC (Space Shuttle Imaging) lançado em 1978 para obter informações oceanográficas na banda 1 e com resolução espacial de $25 \times 25$, sendo o $1^{\circ}$ SAR orbital a fornecer dados de domínio público, forneceu também importantes informações sobre a superfície continental. É possível adquirir imagens SAR de uma mesma área, a partir de uma aeronave ou satélite para extrair informações tridimensionais e dados sobre a velocidade de objetos em movimento.

Outro método de obtenção de dados pelo SAR é o interferométrico. O imageamento interferométrico por RADAR é o processo pelo qual as imagens de um mesmo local no terreno são registradas por diferentes antenas em: 1) diferentes localizações ou 2) tempos diferentes. A análise de dois interferogramas permite medidas precisas sobre o deslocamento de qualquer ponto especifico $\mathrm{X}, \mathrm{Y}, \mathrm{Z}$ encontrados em cada imagem do par interferométrico. $\mathrm{O}$ mapeamento topográfico pela interferometria SAR baseia-se na aquisição de dados a partir de dois ângulos de visada diferentes e assume que a cena imageada não sofreu deslocamento durante o intervalo de obtenção dos dados. As duas medições podem ser feitas por dois radares colocados na mesma plataforma e separados por alguns metros. Isto é denominado de interferometria de passagem única (single-pass interferometry).

A missão SRTM (Space Shuttle Radar Topography Mission), lançado em 11/02/00 foi a primeira a usar este tipo de cobertura interferométrica. Os dados interferométricos SAR podem muitas vezes fornecer informações topográficas (X, Y e Z) que são tão precisas quanto os modelos de elevação digital obtida pelas técnicas fotogramétricas ópticas tradicionais. Além disso, a interferometria pode operar através de nuvens durante o dia ou à noite, despertando grande interesse da comunidade cartográfica. A missão SRTM usou radar de cobertura sintética interferométrica, banda $\mathrm{C}$ e banda $\mathrm{X}$ para adquirir dados topográficos em mais de $80 \%$ da área emersa da Terra, entre $60^{\circ} \mathrm{N} 56^{\circ} \mathrm{S}$, durante 11 dias de duração da missão (JENSEN, 2009, p. 296 -330).

Os dados SRTM, na forma em que foram disponibilizados para nosso continente, apresentam resolução espacial de 3 arcos de segundo ( 90m) e resolução vertical de $1 \mathrm{~m}$. Podem ser adquiridos em diferentes níveis de processamento, como no site do Projeto TOPODATA onde os dados disponibilizados passaram por um processamento computacional para refinamento no tamanho do pixel de 90 para 30m, sendo interpolados pelo método de krigagem. Atualmente é acessível um Modelo Digital de Elevação (MDE) de todo o território nacional, bem como as principais variáveis topográficas associadas: altitude, declividade, 
orientação de vertentes, curvatura vertical das vertentes, curvatura horizontal, delineamento de canais de drenagem e divisores de água e área de captação (FLORENZANO, 2005).

No quadro abaixo, JENSEN apresenta as principais vantagens do Sensoriamento Remoto por RADAR:

\section{Quadro 6: Vantagens do Sensoriamento Remoto por radar}

\section{VANTAGENS:}

\section{PRIMÁRIAS}

- Certas frequências de micro-ondas penetram as nuvens, permitindo o sensoriamento remoto em quaisquer condições meteorológicas;

- Visão Sinóptica de grandes áreas para mapeamento de 1:10.000 a 1:400.000. A cobertura por satélite de países com presença de nuvens é possível;

- A cobertura pode ser obtida em horários especificados pelo usuário, inclusive à noite;

- Permite o imageamento com ângulos de visada rasantes, resultando em perspectivas diferentes, que nem sempre podem ser obtidas por fotografias aéreas;

- Atua em comprimento de onda fora das regiões do espectro eletromagnético óptico e infravermelho, fornecendo informações sobre rugosidade superficial, propriedades dielétricas e conteúdo de umidade.

\section{SECUNDÁRIAS}

- Certas frequências da energia de micro-ondas penetram a vegetação, a areia e os níveis da neve;

- Baseia-se em sua própria fonte de energia, podendo controlar o ângulo de iluminação;

- Permite que a resolução seja independente da distância do objeto, com tamanhos de células de resolução de até $1 \mathrm{x} 1 \mathrm{~m}$;

- As imagens podem ser produzidas com diferentes tipos de energia polarizada $(\mathrm{HH}$, $\mathrm{HV}, \mathrm{VV}, \mathrm{VH})$.

- Pode operar, simultaneamente, em diversos comprimentos de onda (frequências), ou seja, com o potencial de atuação em multifrequências.

- Pode medir propriedades de ondas dos oceanos, mesmo em altitudes orbitais.

- Pode produzir superposição de imagens para observação estereoscópica e para radargrametria.

- Suporta operações interferométricas usando duas antenas para mapeamento 3D e análise de assinatura dos objetos de acordo com o ângulo de incidência.

Fonte: JENSEN, J. R. Sensoriamento remoto do ambiente: uma perspectiva em recursos terrestres. São José dos Campos: Parêntese, 2009, p. 296 


\section{Teoria do Geossistema}

\subsection{Paradigmas da ciência moderna}

A ciência moderna se consolidou sob o paradigma das leis matemáticas quando Galileu fez os primeiros experimentos que deram origem à racionalidade cientificista e Francis Bacon propôs um novo método que viria a tornar-se uma marca distintiva da ciência moderna: a experimentação seguida da indução. A ciência podia ser expressa de forma quantitativa através da linguagem matemática. As bases teóricas postuladas por Galileu e Bacon consolidaram outras correntes de pensamento científico posterior como o de Descartes e Isaac Newton que contribuíram para uma nova forma de pensar e conhecer o mundo: o mecanicismo, que se opunha ao organicismo que concebia o mundo como um organismo vivo orientado para um fim.

A concepção mecanicista via natureza como um mecanismo cujo funcionamento se regia por leis precisas e rigorosas. À maneira de uma máquina, o mundo era composto por peças ligadas entre si, que funcionavam de forma regular e poderiam ser reduzidas às leis da mecânica. Descartes chegou a escrever

Eu não sei de nenhuma diferença entre as máquinas que os artesãos fazem e os diversos corpos que a natureza por si só compõe, a não ser esta: que os efeitos das máquinas não dependem de mais nada a não ser da disposição de certos tubos, que devendo ter alguma relação com as mãos daqueles que os fazem, são sempre tão grandes que as suas figuras e movimentos se podem ver, ao passo que os tubos ou molas que causam os efeitos dos corpos naturais são ordinariamente demasiado pequenos para poderem ser percebidos pelos nossos sentidos. (SERRÃO, 2007, p. 1).

Quando no século XVII Descartes introduziu o conceito do animal como máquina e preconizou outros paradigmas da ciência moderna, houve também uma revolução tecnológica sustentada pelos novos conhecimentos em mecânica. Isso tornou possível a criação da primeira máquina a vapor por James Watts, em 1765, que foi empregada nas fábricas da Inglaterra e transformou radicalmente o sistema de manufatura e a produção têxtil.

Outra corrente filosófica que direcionou a produção do conhecimento científico no começo do século XIX foi o positivismo que defende a ideia de que o conhecimento científico é a única forma de conhecimento verdadeiro, consiste na observação dos fenômenos, opondose ao racionalismo e ao idealismo. Para a abordagem positivista, o estudo do homem pode ser realizado por meio dos métodos das ciências naturais, seguindo sua lógica. O positivismo contemporâneo tem suas bases em Auguste Comte e John Stuart Mill. Ambos os autores advogam ser possível que as ciências humanas e sociais realizem suas pesquisas através das 
ciências físicas, que 1) a sociedade humana é regulada por leis naturais; 2) que os métodos e os procedimentos utilizados para conhecer a sociedade não diferem em nada daqueles empregados para conhecer a natureza; e 3) que, como conclusão, as ciências sociais devem funcionar exatamente segundo o modelo de objetividade, neutralidade e isenção de juízos de valor das ciências da natureza (Löwy, 1985, p. 35-36).

A sólida visão mecanicista da natureza perpetua até os dias atuais, embora refutada no século XIX por Maxwell (1831-79), que mostrou que a radiação electromagnética e os campos electromagnéticos não tinham uma natureza mecânica. Novas aquisições em termos de uma compreensão mais holística dos fenômenos naturais têm permeado os conhecimentos científicos da atualidade. A complexidade da sociedade moderna contribui para a superação do pensamento analítico, sobretudo o cartesiano e o positivismo e a emergência do pensamento sistêmico. O pensamento mecanicista entra em crise, quando a física newtoniana não dá conta de explicar os processos interativos e dissipativos do calor, dando origem à Termodinâmica, por meio dos trabalhos de Jean- Joseph Fourier, Sadi Carnott Jaule.

Bertalanfy, no início do século XX, questionou os paradigmas da ciência mecanicista e propôs uma discussão filosófica sobre o conceito de sistemas. A ciência moderna, que se caracterizava pelo esquema de unidades isoláveis atuando segundo a causalidade, mostrou-se insuficiente diante da complexidade do mundo atual. Nesta perspectiva, os paradigmas da ciência moderna vêm sendo substituídos por noções de totalidade holística, organísmica. A concepção de indivíduo assume o significado de indivisível, tornando o organismo ainda mais unificado.

No organismo vivo verifica-se uma surpreendente ordem, organização, conservação, em meio a uma contínua transformação, regulação e aparente teleologia, opondo-se à maneira mecanicista de proceder, que consistia essencialmente em resolver o organismo vivo em partes e processos parciais. $\mathrm{O}$ organismo era entendido como um agregado de células, a célula, um conjunto de coloides e moléculas, o comportamento, uma soma de reflexos incondicionados (BERTALANFY, 1973, p. 126).

Bertalanfy propôs um estudo interdisciplinar dos organismos em sua totalidade, ao analisar a interação dinâmica que existe entre as partes. Esta tendência se expandiu para diversos campos científicos, com o objetivo de romper com a concepção mecanicista que passou a direcionar as pesquisas científicas ao longo de séculos desde os tempos de Newton e Descartes. Em seu livro, Bertalanfy define Teoria Geral dos Sistemas como uma ciência geral da totalidade, uma disciplina lógico-matemática formal, aplicável às várias ciências 
empíricas. Todo organismo vivo é um sistema aberto. Mantém-se em um contínuo fluxo de entrada e de saída, governado pela interação dinâmica de seus componentes, apresentando importação e exportação, construção e demolição de materiais que o compõe.

Segundo Bertalanfy, a Teoria Geral dos Sistemas é capaz de fornecer modelos a serem utilizados em diferentes campos científicos. Os métodos propostos por Bertalanfy para o estudo dos sistemas é o empírico intuitivo que consiste em examinar os vários sistemas que nele ocorrem e em seguida estabelece enunciados sobre as regularidades que se observam serem válidas. Um segundo caminho é o da teoria dedutiva, que considera o conjunto de todos os sistemas concebíveis e reduz então o conjunto a um tamanho mais razoável (BERTALANFY, 1973, p.133-134).

\subsection{Geossistema}

A visão sistêmica foi introduzida no pensamento geográfico nas décadas de 50 e 60 , em primeira instância na hidrologia e climatologia e posteriormente na geomorfologia. Não existem condições limítrofes entre o espaço do ser humano e o espaço da natureza. Amparado nessa premissa, Victor Sotchava cunhou o termo Geossistema, para a geografia física. Essa abordagem dá suporte metodológico à Geografia Aplicada, favorecendo o planejamento de desenvolvimento socioeconômico. "em condições normais, deve estudar, não os componentes da natureza, mas as conexões entre eles, projetando-se para o estudo da dinâmica, estrutura funcional, conexões, etc.” (SOTCHAVA, 1976). Nesta perspectiva, o pensamento geográfico, até então pautado numa abordagem analítica e descritiva, adquire caráter aplicativo voltado ao planejamento e gestão dos recursos naturais, integrando homem e natureza, de forma a reconciliar o desenvolvimento econômico e social com a manutenção da qualidade e disponibilidade dos recursos naturais. A noção de Geossistema, associa-se à concepção geográfica da natureza, onde homem é partícipe desse meio como elemento biológico e como ser social que atua na preservação e na modificação dos ambientes naturais.

Sotchava afirma que a Geografia Física automaticamente se divorciou de sua principal concepção: a conexão da natureza com a sociedade humana. Embora os Geossistemas sejam fenômenos naturais, todos os fatores econômicos e sociais, influenciando a estrutura e peculiaridades espaciais são tomadas em consideração durante o seu estudo e suas descrições verbais ou matemáticas. 
Geossistemas são umas classes peculiares de sistemas dinâmicos abertos e hierarquicamente organizados. Toda categoria de geossistema (topologia, regional, planetária, intermediária possui suas próprias escalas e peculiaridades qualitativas da organização geográfica. Um modelo representa a reflexão sintética regulada do sistema, expressa por meio de símbolos, signos numéricos ou descrições matemáticas, muitas vezes graficamente, o que na aparência exterior o assemelha a um gráfico. Pode - se distinguir três modelos de geossistema: 1) modelos de componentes funcionais: servem à recepção, transporte, transformação e êxodo de qualquer tipo de matéria em geossistema. Dão ideia da interação dos componentes dentro do geossistema; 2) modelos geômeros-funcionais: são utilizados para refletir o papel funcional dos fáceis ou macrogeócoros e geômeros de outras categorias em geócoros aos quais pertencem. São modelos que não tem correspondentes em outras ciências da terra. O sistema funcional de um geócoro é formado pelos geômeros que o constituem, a modelização ajuda a resolver os mecanismos das conexões funcionais; 3) modelo dinâmico estrutural: tem por finalidade revelar e analisar as diferentes categorias dinâmicas e estados variáveis dos geossistemas, ligados a um geômero primitivo usualmente um fáceis ou um grupo de fáceis. Tal modelo reflete a estrutura de um epifácie ou grupo de epifácies (SOTCHAVA, 1976).

As abordagens teórico - metodológicas sobre geossistemas no pensamento de Sotchava deixou muitas lacunas e flexibilidade no uso do termo, possibilitando reflexões abrangentes e diversificadas sobre o conteúdo, metodologia e escala utilizados por vários geógrafos. Os desdobramentos dessa teoria na França consolidaram o pensamento de Bertrand sobre a paisagem e de Tricart sobre Geomorfologia. Por meio de Bertrand, o conceito de Geossistema é introduzido no Brasil, com a tradução do seu trabalho: Paisagem e Geografia Física global. De acordo com o autor, o estudo da paisagem deve pautar-se no conceito de Geossistema, determinado como uma porção do espaço, resultante "da combinação dinâmica, portanto instável, de elementos físicos, biológicos e antrópicos que, reagindo dialeticamente uns sobre os outros, fazem parte da paisagem, um conjunto único e indissociável, em perpétua evolução". (Bertrand, 2004, p. 141).

A proposta de Bertrand apresenta a paisagem como uma construção de relações dialéticas entre os seus diversos elementos físicos, biológicos, químicos e o seu constante movimento de transformação no tempo histórico, caracterizando as paisagens. Neste sentido, o autor considera o estudo da paisagem de fundamental importância para a Geografia, pois analisa a paisagem de forma articulada transversal e integrada, superando a dicotomia 
sociedade e natureza. Como ele mesmo defendia, "o Geossistema constitui uma base para os estudos de organização do espaço porque ele é compatível com a escala humana”. (Bertrand, 1972, p. 14 apud Guerra et al., 2012).

Sob os princípios da teoria Geossistêmica, Troppmair produz o mapa de Geossistema do Estado de São Paulo. Sua contribuição metodológica se dá no âmbito da interdisciplinaridade entre Ecologia e Geografia. Nesse trabalho, o autor utiliza a sobreposição dos Ecossistemas aos Geossistemas. Esta carta explora a sobreposição de duas sínteses. Na visão de Troppmair e Galina (2006, p. 81), “o geossistema é um sistema natural, complexo e integrado onde há circulação de energia e matéria e onde ocorre a exploração biológica, inclusive aquela praticada pelo homem". Para os autores, a morfologia, dinâmica e exploração biológica são três características primordiais para a classificação de qualquer geossistema. Neste aspecto, se assemelha com Bertrand ao destacar os mesmos componentes.

Na visão de Troppmair, os geossistemas apresentam resistência aos impactos sofridos, uma vez que apesar da modificação local, a estrutura do geossistema não é modificada. Ele considera a dimensão espacial do geossistema como fator importante. Realiza a cartografia de síntese, destacando a importância da geomorfologia, clima e solo. O mapeamento pode ser realizado inicialmente com base em imagens de satélite definindo as categorias dos ecossistemas e geossistemas, sendo que o mapeamento pode ser realizado em macro, meso e micro escala.

Monteiro propõe o mapa de Qualidade Ambiental sob a abordagem sistêmica e integra a relação sociedade e natureza utilizando o conceito de Geossistema. Através de sua obra Teoria e Clima Urbano, contribui para o avanço dessa temática. O autor propõe "critérios de escolhas" para o embasamento de sua abordagem, sendo um deles o "modelismo", o qual justifica dizendo que "o clima urbano, para o desenvolvimento de sua pesquisa e aperfeiçoamento continuado, necessita tanto do mapeamento quanto da diagramação". Dessa forma, Monteiro interpreta e adapta a Teoria Geral dos Sistemas na elaboração de um modelo para o estudo do clima urbano, fazendo uso de abordagens qualitativas e quantitativas, oferecendo um exemplo prático e eficiente de instrumento de gestão e planejamento, além de adaptar e definir o conceito de hierarquia, organização e funcionalidade em sistemas abertos, estabelecendo subsistemas e canais de percepção que fazem parte do sistema do Clima Urbano.

Monteiro propõe três etapas em sua metodologia: a análise - na qual ocorre a integração dos elementos naturais e antrópicos; integração - associa os recursos, usos e 
problemas na mesma etapa e na síntese define as unidades homogêneas. Os mapas de Qualidade Ambiental resultam de uma prática interdisciplinar, uma vez que esta questão é multifacetária. Sua produção destaca a relevância da antropização para a caracterização dos Geossistemas e também enfatizam as limitações das técnicas de representação gráfica para obtenção de resultados analíticos e sintéticos mais concretos.

$\mathrm{Na}$ perspectiva de Monteiro, os produtos cartográficos com base geossistêmica geram muitas possibilidades de leitura do meio ambiente, pois expressa de forma clara e lógica a dinâmica social ocorrida no espaço. "O aprimoramento dessa integração holística é um prérequisito necessário à compreensão da qualidade ambiental, ponto de partida para avaliações quantitativas e diagnósticos mais precisos possibilitando prognósticos ambientais" (Ross, 2009, 34).

\subsection{A Cartografia na teoria geral dos sistemas}

\subsubsection{Paul Ozenda}

Os estudos que subsidiam o conhecimento sobre recursos naturais realizados a partir da concepção sistêmica utilizam a cartografia para elaborar cenários ambientais. Paul Ozenda tem se dedicado à Cartografia Temática utilizando as variáveis ambientais para aprofundar os conhecimentos sobre a vegetação das grandes cadeias de montanhas na Europa. Por meio da síntese, concentrou-se nas áreas de biologia geral, representando os seguintes aspectos da vegetação: adaptações, o parasitismo, condições críticas (aridez e altitude), estrutura e distribuição dos principais ecossistemas, aplicações para a conservação de ambientes naturais e controle de perturbações, distribuição dos ecossistemas, aplicações para a conservação de ambientes naturais e controle da poluição. Sua pesquisa está centrada numa cartografia mais complexa.

O mapa de vegetação é elaborado com base na distribuição das plantas em relação ao meio em que estão inseridos sem desprezar a participação antrópica nas modificações do ambiente natural. Sua contribuição para o mapeamento dos ecossistemas permite a localização das áreas de fronteira, muito sensível à mudança, e particularmente importante para a definição de medidas de controle e conservação do meio ambiente. As perturbações do meio ambiente são observadas em seus trabalhos como aceleração da extinção de muitas espécies devido à exploração abusiva, a introdução de espécies que perturbam o ambiente e, 
especialmente, à destruição de comunidades biológicas, pela sobrepesca, as extensas áreas de monoculturas, a degradação do solo e poluição, com destaque para a complexidade de opções para medidas de conservação nas regiões de deserto e dos Alpes. Ele sublinha que as atividades humanas bem estudadas podem contribuir para a manutenção dos ecossistemas seminaturais muito ricos e que cada caso requer uma análise especial.

Os documentos cartográficos produzidos por Ozenda são marcados pela descrição da vegetação e sua distribuição, o que resulta em um estudo analítico em uma divisão em setores, que elabora mapas detalhados das diferentes regiões Alpinas (Norte de Itália, Suíça, Baviera) e com os comentários recentes de unidades florestais. Seus trabalhos também são marcados pelo estudo do conceito de estágio da vegetação, o autor critica o uso que a Biogeografia faz desse conceito ao referir- se apenas à geomorfologia ou altitude bruta, independentemente da latitude, sem analisar as comunidades de espécies dominantes. É necessário procurar uma definição rigorosa do estágio de vegetação, com base em estudos acurados das comunidades de plantas, considerando o bioclima dentro de cada etapa. Ozenda realiza um trabalho cartográfico denominado por ele como de Síntese. A cartografia de síntese considera a fusão dos elementos em "tipos". Estes devem evidenciar conjuntos espaciais que são agrupamentos de unidades de análise elementares caracterizadas por agrupamentos de atributos ou variáveis (ARRUDA, 2011, p. 26)

\subsubsection{Tricart}

Na Cartografia Temática, a Teoria Geral dos Sistemas fornece embasamento metodológico para a representação de cenários ambientais. As representações das variáveis ambientais por meio dos mapas têm se configurado num importante instrumento de planejamento das diferentes ações sobre o meio ambiente, pois permite uma visão holística da situação dos recursos naturais. Tricart, a partir da concepção da Teoria Geral dos Sistemas encontrou sustentação metodológica para construir a classificação Ecodinâmica dos meios ambientes (1965) e posteriormente em 1977 propôs a análise morfodinâmica ao considerar o conjunto de variáveis ambientais, naturais ou elaboradas pelo homem que, fundamentam comportamentos dinâmicos mais próximos da estabilidade ou da instabilidade a partir da análise do relevo.

Nas Unidades Ecodinâmicas a morfogênese é o elemento que predomina na dinâmica e corresponde a resultados de causas naturais e antrópicas. Fenômenos como vulcanismos, a 
cobertura vegetal aliada às influências climáticas e as intervenções humanas promovem a brusca ativação morfodinâmica, desencadeando processos erosivos com rápida degradação dos solos. Quando as unidades sofrem impactos da ação antrópica, tendem a perder seu estado de equilíbrio passando à categoria de instáveis. Observando a dinâmica da pedogênese e morfogênese é possível identificar o grau de vulnerabilidade ambiental. A síntese desse estudo manifesta-se na Cartografia, enquanto instrumento imprescindível ao diagnóstico ambiental (CASSETI, 2005).

Os estudos geomorfológicos realizados por Tricart tiveram sua concretização na Cartografia Temática. A variável geomorfológica tornou-se a base da pesquisa e não sua concretização gráfica, a base e o resultado de um estudo (CASSETI, 2005). Os mapas geomorfológicos elaborados por Tricart expressam as relações espaciais, sintetizadas através dos compartimentos, contribuindo para os estudos de interesse geográfico como a vulnerabilidade e a potencialidade dos recursos do relevo.

A metodologia utilizada por Tricart parte de um processo empírico que exige tanto o trabalho de gabinete quanto de campo, com utilização de cartas topográficas e seus subprodutos - hipsometria, hidrografia e clinometria -, cartas geológicas, pedológicas, de uso e ocupação do solo e imagens de sensoriamento remoto. A representação da carta geomorfológica tem início com a adição das curvas de nível em base cartográfica, extraídas das cartas topográficas. O autor chama atenção para a importância dos dados estruturais na representação e as relações entre tempo e espaço em cada unidade geomorfológica. (CASSETI, 2005).

O sistema de símbolos proposto por Tricart (1965) permite estudar a evolução das formas de relevo contemplando dados de quatro naturezas diferentes:

- Morfometria: fundo topográfico com redes de drenagem e curvas de nível; os dados como declividade das vertentes, hierarquia da rede de drenagem, altura das bordas de terraços, de cornijas ou rebordos erosivos podem ser acrescentados desde que não comprometam legibilidade da carta;

- Morfografia: através dos símbolos as formas de relevo são espacializadas na carta indicando a noção dos processos responsáveis por estas formas;

- Morfogênese: os símbolos devem representar os processos morfogenéticos atuantes na área que deram origem às formas. Tricart (1965) afirma que é preciso compreender o modo pelo qual as formas atualmente visíveis se originaram; 
- Cronologia: apresenta o momento da história morfogenética que o conjunto das formas de relevo se desenvolveram.

A cartografia proposta por Tricart se constitui num importante instrumento de espacialização dos fatos geomorfológicos, pois ao analisar as formas de relevo e suas características morfológicas, materiais componentes, processos atuantes, intervenções antrópicas na morfologia natural, compreende-se o funcionamento do modelado terrestre e suas condicionantes relacionadas às atividades humanas e formas de organizações espaciais, oferecendo subsídios aos estudos de suscetibilidade aos processos erosivos, movimentos de massa e inundação, além de indicar as fragilidades e potencialidades dos ambientes naturais em função dos usos atuais e futuros (CASSETI, 2005).

\subsection{Principais características do meio físico numa abordagem sistêmica}

A abordagem sistêmica serve ao geógrafo como instrumento conceitual para tratar dos conjuntos complexos que resultam na organização espacial e que envolve a investigação da morfologia da superfície terrestre e sua interação com a dinâmica própria da natureza. Ao geógrafo torna-se imprescindível o conhecimento da integração das forças atuantes para compreender as formas resultantes. CHRISTOFOLETTI (1986-1987, p. 123) afirma que

Essa interação também pode ocorrer sob diversas escalas de grandeza: compatibilizar os materiais; processos e as características de determinado solo; os processos morfogenéticos com a morfologia de vertentes; o transporte de sedimentos e aspectos da morfologia de canais; os balanços energéticos e hídricos com a morfologia topográfica e cobertura vegetal.

$\mathrm{Na}$ abordagem geossistêmica como proposta teórico-metodológica, as relações sociedade e natureza, intrínseca ao pensamento Geográfico, são analisadas em maior grau de profundidade possibilitando o diagnóstico da realidade e atuando na preservação e na modificação dos ambientes naturais.

\subsubsection{Solo}

Desde a antiguidade quando o homem descobriu as técnicas agrícolas, o solo passou a constituir uma condição que determina a ocupação humana nos mais diferentes lugares da Terra. A fertilidade, a abundância de água, e as regiões mais aplainadas são fatores que favorecem a fixação humana. O descobrimento das técnicas permitiu intervenções no solo de 
forma a aproveitar suas potencialidades e intervir em seus fatores limitantes. O solo apresenta importância direta não só para a sobrevivência humana, mas para a fauna e a flora do planeta Terra.

Dos avanços que a ciência alcançou nas últimas décadas, o estudo do solo e o planejamento adequado das ações sobre o mesmo deve estar presente na ordem do dia. No Brasil, a EMBRAPA tem desenvolvido pesquisas e um monitoramento que tem por objetivo direcionar as práticas agropecuárias no país, com vista a amenizar os impactos destas atividades sobre os solos. Com o auxílio das geotecnologias e dos SIGs, a ação sobre o solo pode ser planejada, o monitoramento permite maior conhecimento da área estudada, envolvendo suas potencialidades e limites, como fatores relacionados à erodibilidade dos solos, declividade, uso e ocupação indevida, combate aos incêndios. Estas técnicas constituem importantes aliados ao estudo e manejo do solo, principalmente no Brasil, que possui grande extensão territorial.

A Pedologia e a Edafologia definem o solo como uma massa natural integrante da superfície da Terra, capaz de suportar as plantas, uma vez que as rochas, enquanto superfícies consolidadas não as suportam, pois o seu enrijecimento impede a penetração das raízes, a retenção de água e ainda impossibilitam que os elementos nutritivos nelas contidos sejam absorvidos pelas plantas uma vez que se encontram cristalizados no interior das rochas (LEPSCH, 2010)

É um produto resultante da desagregação e decomposição das rochas sob ação dos agentes intempéricos. Esses processos que atuam na formação dos solos são de ordem física (decomposição, dilatação térmica, ação do gelo e expansão coloidal) que agem na fragmentação da rocha e por processos químicos que atuam modificando sua composição química.

O intemperismo químico tem sua ação intensificada pela água associada ao aumento da temperatura. Nesta perspectiva, as regiões de clima quente e úmido tendem a sofrer maior decomposição dos minerais. As reações químicas mais importantes que atuam nesse processo são: oxidação, carbonatação, hidrólise, hidratação, dissolução e reconstituição química. Elas transformam o arranjo original dos minerais e desprendem elementos químicos que estavam retidos na estrutura inicial como o sódio, o potássio, cálcio e magnésio. Com exceção do sódio, os demais são essenciais ao desenvolvimento das plantas.

Associado ao intemperismo que transforma as rochas em material friável, os restos de plantas que se decompõe e se mistura, formam o húmus liberando diversos nutrientes, em 
especial o nitrogênio melhorando suas propriedades físicas favorecendo a retenção da umidade do solo por mais tempo. Os fenômenos que atuam na formação dos solos são desencadeados de forma dinâmica (LEPSCH, 2010).

\subsubsection{Fatores que influenciam na formação do solo}

Os estudos realizados por Dokoutchaiev (1898) evidenciaram a existência de cinco fatores de ação combinada que favorecem a formação do solo: clima, natureza dos organismos, material de origem, relevo, idade do lugar.

1) Clima - os elementos do clima, cuja atuação sobre a pedogênese é mais direta, são: radiação solar (calor), precipitação pluvial (água) e pressão atmosférica (vento). O calor influi diretamente nas atividades das reações químicas e processos biológicos que ocorrem no perfil do solo. A água promove a reação de hidrólise (ataque de íons H+ à estrutura de minerais, com consequente colapso e destruição dos minerais) onde ocorre a hidratação do solo. A água excedente atua no desenvolvimento do perfil do solo conforme a sua quantidade: regiões onde a quantidade de água excedente é grande, geralmente apresentam solos mais profundos, pois a velocidade dos processos pedogenéticos é mais acentuada. $\mathrm{O}$ vento causa a erosão eólica e o ressecamento da superfície do solo.

As condições climáticas ainda se relacionam diretamente com o tipo de vegetação local, que pode ter grandes variações botânicas. Os processos de intemperismo físico e químico não ocorrem isoladamente, mas simultaneamente. Conforme as condições climáticas podem predominar os processos de intemperismo físico ou os de intemperismo químico. De acordo com PEREIRA E ALMEIDA (2010, p. 219).

o clima através de seus componentes como a chuva, temperatura, vento, direciona os processos intempéricos e desempenham papel na formação do solo, que quando ainda jovem, guarda evidentes características da rocha matriz, mas com o passar do tempo as perde e adquire íntima ligação com o clima e a vegetação dominante.

2) Os organismos compreendem: a) os microrganismos (microflora e microfauna). São algas, bactérias ou fungos e atuam na decomposição dos restos de vegetais e animais e na formação das partículas do solo que formam os torrões, retiram o nitrogênio do ar para fixá-lo aos vegetais; b) vegetais (macroflora): com seu sistema radicular abrem fendas nas rochas acelerando o processo de intemperismo; as folhas caídas decompõem-se sob ação dos microrganismos formando as camadas superiores do solo. 
A vegetação também participa indiretamente da conservação do solo contra os processos erosivos. A macroflora caracteriza-se pela vegetação em geral. Influencia no intemperismo físico (pela ação das raízes ao penetrarem nas fendas das rochas) e no intemperismo químico (pela ação dos ácidos orgânicos resultantes da sua decomposição). Outra atuação importante está na capacidade das raízes das árvores de grande porte, que penetram nos solos e são capazes de capturar nutrientes de camadas mais profundas. Quando suas folhas caem, devolvem esses nutrientes ao solo, permitindo que eles sejam incorporados às camadas mais superficiais. Esse processo é essencial nas florestas tropicais úmidas, onde a precipitação elevada promove uma constante lixiviação que empobrece os solos de alguns nutrientes essenciais. O material húmico (resultante da decomposição da matéria orgânica) é um coloide que misturado ao material mineral funciona como uma liga, formando agregados mais estáveis, que resistem mais à erosão.

c) animais - Os solos apresentam uma fauna variadíssima, composta por microorganismos (protozoários, rotíferos, nematoides), mesofauna (ácaros, colêmbolos) e macrofauna (minhocas, centopeias, insetos). Os animais que se abrigam no solo trituram restos dos vegetais, abrem galerias e misturam os materiais entre os diferentes horizontes do solo, realizando a aeração e movimentação dos materiais, além de contribuírem na adição de matéria orgânica pela excreção e/ou pela sua decomposição. De acordo com PEREIRA e ALMEIDA (2010, p. 220)

Todos os organismos que vivem no interior do solo contribuem de alguma forma para o seu desenvolvimento e para sua bioestrutura, esta se caracteriza pela grumosidade, ou seja, porosidade que permite infiltração da água e penetração de ar e das raízes.

d) homem: a atuação humana destaca-se também pelas inúmeras intervenções capazes de modificar todos os fatores. As atividades humanas também são responsáveis pelas alterações nas estruturas do solo. Desmatamento, cultivo de terras, uso de agrotóxicos, exploração mineral são algumas das atividades humanas que, quando não planejadas podem comprometer a qualidade e até a manutenção deste recurso numa escala temporal, para gerações futuras. $\mathrm{O}$ conjunto destas atividades associadas ao manejo inadequado culmina com erosão, a compactação e o aumento da salinidade do solo.

3) Relevo - A topografia regula a velocidade do escoamento superficial das águas pluviais que dependem da vegetação para se infiltrar nos perfis, favorecendo as reações químicas ou lixiviação dos produtos solúveis. Os solos se desenvolvem de forma heterogênea ao longo do relevo. Encostas possuem solos menos desenvolvidos que áreas de baixadas que 
permanecem mais tempo encharcados. Os terrenos de declive sofrem mais os processos erosivos.

4) Tempo - Todas as propriedades morfológicas requerem tempo para se manifestarem no perfil do solo. O solo pode ser considerado maduro quando os horizontes já estão bem desenvolvidos. Outros processos que envolvem a formação do solo são desenvolvidos ao longo do tempo como translocação de argila e remoção de sais minerais, estágio de aprofundamento do solo, caracterizando-o maduro ou jovem. O processo de amadurecimento do solo não é homogêneo porque dependem dos demais fatores como clima, topografia e material de origem (LEPSCH, 1977, p.56-69).

\subsubsection{Composição do solo}

O solo é composto por partículas minerais, materiais orgânicos, água e ar. O primeiro constituinte é decorrente dos minerais componentes da rocha matriz. O material de origem é um fator de resistência à formação do solo. O seu grau de desenvolvimento depende do tipo de material e de sua exposição aos agentes intempéricos. Os materiais de origem são classificados em quatro categorias:

a) materiais derivados de rochas claras (ácidas, ígneas ou metamórficas como os granitos, gnaisses, xistos e quartizitos), que se formam pela consolidação do magma ou pelo seu metamorfismo ou de rochas sedimentares e são ricos em silício;

b) materiais derivados de rochas escuras (basaltos, diabásios, gabros e anfibolitos). São formados pela solidificação do magma e são pobres em silício;

c) materiais derivados de sedimentos consolidados como os arenitos, arcósias, siltitos, argilitos e rochas calcárias. Os minerais mais solúveis como cálcio, magnésio e potássio são carreados pelas águas das chuvas, este fenômeno é comum em regiões de clima tropical;

d) sedimentos inconsolidados tais como os aluviões recentes, dunas de areias, cinzas vulcânicas, loess, materiais de origem pedimentar e sedimentos orgânicos. Muitas das características do solo são determinadas pelo material de origem.

As rochas de qualquer origem, quando expostas na superfície e sujeitas à atuação de agentes atmosféricos, são alteradas e decompostas, dando origem a um manto de intemperismo particularmente profundo nas áreas tropicais, que vem constituir os solos em seu sentido mais amplo: sua fertilidade decorre em grande parte da decomposição química das rochas que lhe deram origem (CÂMARA, 1998). 
A matéria orgânica resulta do acúmulo e decomposição de restos de vegetais e animais que posteriormente se transforma em húmus. Esse material é importante para o solo porque são agentes cimentantes na formação dos agregados, colaboram com as características físicas como: permeabilidade, porosidade e retenção de água. Também nutrem os microrganismos que ajudam no desenvolvimento dos vegetais como as bactérias que fixam o nitrogênio do ar.

A água fica armazenada no solo e as plantas se utilizam dela para o seu desenvolvimento. Este constituinte fica retido nos poros ou nos torrões e é reposta pela chuva ou pela irrigação e por fim, o ar ocupa os espaços porosos do solo não preenchidos pela água. Nem todos os solos tem a capacidade de reter água. A variação ocorre em função da textura, estrutura e matéria orgânica. Os solos arenosos armazenam menos água que os argilosos ou barrentos. A água também atua lixiviando os minerais do solo tornando-os mais ácidos (LEPSCH, 2010).

\subsubsection{Características do solo}

Sob ação da gravidade de uma parte para outra, substâncias translocam-se, sofrem remoção, adição e transformação, formando os horizontes do solo que apresentam como características cor, textura, estrutura, consistência e espessura dos horizontes. A cor auxilia na identificação e delimitação dos horizontes do solo. As tonalidades ressaltam suas condições morfológicas: solos escuros indicam elevados teores de matéria orgânica decomposta, o vermelho denota solos bem drenados com presença de óxido de ferro e os cinza-azulados indicam excesso de água no perfil, situados nas baixadas úmidas próximas aos rios e riachos.

A textura corresponde ao conjunto de partículas individuais ligadas umas às outras, mas com tamanhos variados como a areia, limo e argila. Geralmente um horizonte é constituído da combinação destas três texturas. Sua classificação é determinada pela quantidade de material presente no perfil, como arenoso (textura grosseira), argilosa (textura fina) e barrenta quando apresenta quantidade equilibrada dos três materiais.

A estrutura é determinada pelas condições naturais dos agregados ou torrões, ocasionadas por dois fatores: ajuntamento das partículas do solo causadas por substâncias com propriedades cimentantes como os produtos orgânicos provenientes da decomposição de restos de vegetais e minerais como óxidos de ferro e alumínio. Podem ser classificados sem estrutura quando não ocorre agregação ou arranjamento ordenado das partículas ou estrutura 
em grãos simples, no caso dos solos arenosos e estrutura maciça para os argilitos e siltitos com aglomerações.

Os solos com estrutura podem apresentar o grau de coesão fraco, moderado ou forte. Esses três graus são definidos em função da resistência de agregados e pela proporção entre materiais agregados e não agregados. Sua estrutura afeta diretamente o crescimento das plantas, pois sua compactação influencia na disponibilidade de água e oxigênio. A estrutura do solo é classificada de acordo com a forma, o tamanho e o grau de desenvolvimento dos torrões. A forma classifica-se em laminar quando o arranjo das partículas está organizado no plano horizontal, prismático quando as partículas do solo estão arranjadas em torno de uma linha vertical dominante e em blocos quando as três dimensões da unidade estrutural são aproximadamente iguais (LEPSCH, 2010).

\subsubsection{Vegetação}

A vegetação que se desenvolve sobre os diferentes lugares da superfície terrestre é resultado da combinação de fatores edáficos, climáticos, bióticos e da forma como o ser humano interfere sobre o meio ambiente. PEREIRA e ALMEIDA (2010 p. 198) ainda relacionam acidentes geográficos, enquanto um fator que contribui para a dispersão ou como barreira intransponível à circulação não só de espécies vegetais, mas de organismos biológicos por toda a biosfera. Independentes das características ou do grau de endemismos das espécies vegetais das diferentes regiões da biosfera, elas exercem papel importante para a manutenção e conservação de outras formas de vida do lugar em que se desenvolveu, de forma que a sua retirada por completo ou parcial compromete a diversidade biológica, a qualidade e a quantidade disponível dos recursos hídricos e a dinâmica climática. As regiões tropicais do planeta, onde se acumula maior incidência de luz solar e elevadas taxas de precipitação, são as que registram maior diversidade biológica.

O equilíbrio dessa dinâmica natural é condição para a manutenção das formas de vida. Todos os elementos que propiciam o desenvolvimento da vegetação estão relacionados de forma sistêmica e devem ser estudados nesta perspectiva. A qualidade do solo, sua formação e conservação estão diretamente relacionadas com a cobertura vegetal que o recobre. Solos desprovidos de vegetação são suscetíveis aos processos erosivos, sem vegetação, as águas pluviais escoam com maior intensidade, lixiviando os minerais que garantem a fertilidade ao solo. É a vegetação que também fornece matéria orgânica ao solo através de sua 
decomposição que alimenta a microvida, favorece a formação de agregados, tornando-o mais resistente. É também responsável pela diminuição dos impactos das gotas de chuva sobre a terra, altera a distribuição do tamanho das gotas, afetando a energia cinética da chuva, além de ajudar na formação de agregados, uma vez, que a matéria orgânica enquanto um elemento ligante deixa os solos mais resistentes (GUERRA \& CUNHA, 1998).

O vento também atua sobre solos desprovidos de camada vegetal, transportando as partículas que compõe a camada superficial do solo. O sistema radicular das plantas é responsável pela porosidade dos solos, permitindo a infiltração das águas das chuvas e o abastecimento dos lençóis freáticos. Nas encostas, a vegetação controla e previne a movimentação de massas. De acordo com GUERRA e CUNHA (2010, p. 359)

"A cobertura vegetal reduz as taxas de erosão do solo através de sua densidade, da possibilidade de reduzir a energia cinética das chuvas, através da intercepção de suas copas e de formar húmus, importante para a estabilidade e teor de agregados dos solos. Tem papel importante na infiltração e na redução do escoamento superficial."

Como o meio ambiente constitui um sistema altamente integrado, a alteração de qualquer elemento natural influenciará nos demais. A conservação dos rios depende da vegetação, que também determinará a manutenção das espécies animais que vivem naquela área. A ausência de uma visão integral desse meio, sem medir as consequências de ações isoladas, tem acarretado ao meio ambiente, problemas sérios, o que posteriormente recai sobre o próprio homem (TRICART, 1977).

Quando uma área é ocupada com pastagens, agricultura e pecuária e o desmatamento é precedido de queimadas, o solo fica compactado perdendo sua estabilidade física ficando cada vez mais vulnerável à erosão. Porém não é só o solo edáfico que é alterado; com esse processo, toda a sua estrutura já não é mais a mesma e são facilmente degradados pela ação pluvial. Nessas condições, acontece também o transporte de sedimentos que são depositados no fundo dos rios provocando o seu soterramento. Sobre esse aspecto Tricart (1977) afirma que

[...] a vegetação melhora indirectamente a qualidade da água. As águas freáticas são quase sempre de boa qualidade e podem ser mais facilmente protegidas contra a poluição. Mesmo o escoamento hipodérmico assegura certa filtragem, que o escoamento sensu stricto e as circulações cársicas rápidas não sofrem.

A vegetação que se forma naturalmente às margens de rios, nascentes e outros corpos de água denominada de matas ciliares é responsável pela proteção dos cursos de água, evita os 
processos erosivos que atacam o solo às margens dos rios e mantém o equilíbrio da vida silvestre, as raízes das plantas ajudam na porosidade do solo que por sua vez abre caminhos para a água infiltrar abastecendo os lençóis freáticos e mananciais. Com a ausência dessa massa de vegetação, os sedimentos são carregados com facilidade depositando-se nos cursos de água e culmina no seu assoreamento. Isso também causa a desfiguração da paisagem à beira dos rios. Outro impacto causado pela retirada das matas ciliares é a diminuição da vida silvestre que contribui para manter o equilíbrio natural do ecossistema aquático.

São diversos agentes responsáveis pela degradação das matas ciliares. Entre eles podemos destacar as práticas agrícolas. Estas terras são consideradas de alto teor de fertilidade. O uso da terra no Brasil foi marcado pela substituição da mata nativa pela implantação de outras culturas. A depender do cultivo empregado, os danos podem ser ainda maiores, visto que toda a vida natural deste local sofrerá alterações. As atividades extrativistas que retiram a madeira, a exploração de materiais de construção como areia e argila, que servem de apoio às margens dos rios, e a expansão urbana não planejada, retiram a mata ciliar e ainda se aproveitam dos cursos de água para depositar esgotos domésticos e dejetos industriais.

Após longo período histórico de devastação e exploração dos recursos naturais no Brasil, sem reflexão e planejamento adequado que respeitasse seus limites e potencialidades, somente em 1965 o poder público passou a intervir de forma legal nas formas de uso e apropriação dos recursos naturais através do Código Florestal. Sobre este aspecto, MULLER (2000) afirma que mesmo diante da severidade da legislação pouco se tem feito para efetivála. O processo de degradação das matas ciliares ainda é uma realidade muito comum no país. Ele atribui a permanência dessa prática destrutiva à dimensão territorial do Brasil, às dificuldades de monitoramento das zonas florestais mais distantes, à falta de recursos financeiros empregados na capacitação de pessoas e na aquisição de tecnologias adequadas ao monitoramento e à ausência de políticas públicas comprometidas verdadeiramente com as causas ambientais. Em vista disso, é necessário que em complemento à ação repressora sejam implantadas alternativas que visem à preservação das matas ciliares e à recuperação de áreas degradadas.

\subsection{6 Água}


A água é a substância encontrada em maior quantidade na superfície da Terra e é a principal responsável pela manutenção da vida no planeta. Sua origem está associada com a formação da atmosfera quando o planeta entrou em processo de resfriamento geral dando origem as primeiras chuvas, o que possibilitou ao longo do seu tempo geológico a formação dos oceanos, rios e lagos.

Os rios podem ser definidos como cursos naturais de água doce com canais definidos que escoam em direção ao oceano, lago ou outro rio. São formados a partir de uma precipitação (chuva, neve) ou quando a água que se acumulou no subsolo, decorrente do processo de infiltração, aflora na superfície dando origem às nascentes. Estas acontecem numa quebra de declive originada por descontinuidades litológicas, de forma geral no contato do sedimentar com o cristalino. São esses pontos de ressurgência que alimentam a drenagem.

As águas doces possuem particularidades próprias na formação de organismos vivos que se mantém de forma harmônica formando um ecossistema. BRAGA (2002) define este como um sistema estável, equilibrado e autossuficiente, onde toda a sua extensão é caracterizada por elementos topográficos, climáticos, pedológicos, botânicos, zoológicos, hidrológicos e geoquímicos quase que invariáveis. Os ecossistemas de água doce são bastante vulneráveis à ação antrópica e qualquer intervenção do homem nesse meio pode causar alterações tanto nas formas de vida quanto na qualidade da água.

Segundo ODUM (2004) os habitats de água doce ainda podem ser classificados em comunidades lóticas (águas correntes, nascentes, rios) e comunidades lênticas (águas calmas lagos, lagoas, charcos, pântanos) cada um desses habitats possuem condições próprias que possibilita a manutenção da vida das espécies em equilíbrio osmótico com o meio. Os cursos de água podem ser considerados um ecossistema aberto, pois estão relacionados com o ambiente ao seu redor.

As comunidades lóticas estão mais suscetíveis a qualquer variação ocorrida no meio. Dentre os principais fatores que influenciam nas comunidades lóticas podemos destacar a velocidade da corrente que é determinada pela declividade do terreno, pela rugosidade do leito do curso de água e pela sua profundidade e largura.

A corrente é responsável pela distribuição de gases vitais e sais que alimentam os organismos vivos. Quando o homem intervém nesse meio, alterando os aspectos topográficos ou retirando a cobertura vegetal, os processos erosivos que atacam o solo através do escoamento das águas das chuvas podem provocar intensas modificações nas condições naturais dos cursos de água. 
Ainda podemos destacar a oxigenação que em vista da pouca profundidade, da grande superfície exposta e do movimento constante da massa líquida, os cursos de água apresentam grande quantidade de oxigênio, mesmo sem a presença de plantas verdes. Por isso a fauna de água doce é extremamente sensível à falta desse gás. Nessas condições, a oxigenação dos rios é afetada principalmente por resíduos sólidos que podem ser de origem doméstica ou industrial, quando são expostos próximos aos cursos de água ou lançados em rios sem nenhum controle. Os núcleos urbanos se desenvolveram em uma complexa interação com o meio ambiente, pois a falta de políticas públicas direcionadas a disciplinar o uso e ocupação do solo promoveu o crescimento desordenado das cidades e ainda nos dias atuais tem como desafio o destino adequado do lixo e esgotos domésticos e industriais. O meio ambiente sofre intensa pressão com as aglomerações humanas como a crescente poluição das águas subterrâneas e o assoreamento de rios e córregos, ocupação de encostas e outras áreas de risco com moradias inadequadas e inseguras, demanda crescente de recursos naturais (solo, água, biodiversidade) e de energia; aumento contínuo da área impermeável e a eliminação da cobertura vegetal, impedindo a infiltração das águas da chuva.

As atividades agrícolas também contribuem para o agravamento da poluição das águas dos rios. O uso indiscriminado de agrotóxicos (herbicidas, inseticidas, fungicidas, acaricidas, entre outros) também tem causado danos a esse meio. No extrativismo mineral, o mais preocupante para os recursos hídricos é a exploração de minerais metálicos e substâncias não metálicas que são muito solúveis e podem gerar outras substâncias tóxicas que afetam o seu equilíbrio natural (HIRATA, 2003).

As mudanças de temperatura da água também afetam o equilíbrio da vida aquática. A água possui propriedades térmicas que agem minimizando as variações de temperatura com amplitudes térmicas baixas e trocas lentas de calor se comparadas com as que ocorrem no ar. Em vista disso, os organismos aquáticos são estenotérmicos com pouca tolerância às oscilações de temperatura (ODUM, 2004). Em decorrência da ação antrópica, as condições térmicas podem ser alteradas através das mudanças climáticas decorrentes da poluição da atmosfera, enquanto as radiações ultravioletas provocam a eliminação de indivíduos unicelulares. Quanto maior a temperatura, maior o consumo de oxigênio pelos peixes. Ela também influi no metabolismo dos organismos aquáticos, altera a viscosidade e a densidade da água, com isso os organismos do plâncton não podem sustentar-se indo para o fundo. Segundo ODUM (2004, p. 430)

os efeitos nocivos locais da poluição térmica nos ecossistemas aquáticos podem enumerar-se como se segue: (1) uma subida na temperatura da água 
aumenta com frequência a suscetibilidade dos organismos e materiais tóxicos [...]. (3) As temperaturas elevadas tendem a favorecer a substituição das populações normais de algas por outras menos indesejáveis [...]. (4) A medida em que a temperatura da água sobe, os animais precisam de mais oxigênio.

ODUM (2004, p. 420) ainda afirma que outro fator importante é a natureza do fundo que influencia de forma direta no habitat dos tipos de organismos. Quando o fundo é constituído de rochas, oferece condições para a fixação de plantas e animais. O fundo de superfície pouco firme e variável é propício à vida de seres aquáticos denominados bentos que vivem em superfície sólida e submersos, sendo fixos ou móveis. Já em água mais funda com corrente mais lenta se desenvolve os néctons, que são organismos que tem meios de locomoção própria, como é o caso dos peixes.

Outra forma de degradação de ambientes aquáticos é a eutrofização. Esta é resultado do enriquecimento com nutrientes de plantas, principalmente fósforo e nitrogênio que são despejados de forma dissolvida ou particulada em lagos, rios e represas e são transformados em partículas orgânicas pelo metabolismo das plantas. Esta acontece de forma acentuada pela intervenção humana quando esgotos domésticos ou industriais e fertilizantes, aplicados à agricultura, são lançados sem controle em ambientes aquáticos e aceleram o processo de enriquecimento das águas, o que provoca o rápido desenvolvimento de plantas aquáticas (cianobactérias) ou algas verdes - azuis que produzem substâncias tóxicas que prejudicam a saúde do homem, provocam a morte e intoxicação de animais ou o crescimento de plantas aquáticas superiores (aguapé ou alface-d'água), que se decompõem e liberam mais matéria orgânica. Entre os principais efeitos da eutrofização podemos destacar a anoxia (ausência de oxigênio), que provoca a morte de peixes que também libera gases tóxicos e com odor, a acentuada queda da biodiversidade e o número de espécies de plantas e animais.

Quanto às obras de engenharia, estas causam grandes impactos em ambientes fluviais. A construção de barragens modifica o tipo de ecossistema, a situação lótica passa a ser lêntica (água parada), rompendo com o equilíbrio natural do rio. GUERRA (1998, p.240) destaca como principais impactos: o levantamento do nível de base local, que altera a forma do canal e a capacidade do transporte sólido, provocando o assoreamento na desembocadura e no fundo do vale. Gera ainda o aumento de sedimentos para o reservatório, a inundação de áreas próximas à obra e ainda modifica a biota fluvial. As represas podem trazer grandes prejuízos às terras e as populações, a montante das mesmas, em função da inundação do terreno. Em climas semi-áridos, um grande volume de água é perdido por evaporação. Acontece também 
a sedimentação no reservatório e a montante, pois reduzem a velocidade de fluxos dos rios que interceptam provocando a deposição da carga de sedimentos trazidos por estes.

A sociedade moderna tem apresentado cada vez mais uma intensa dependência dos recursos hídricos que tendem a ficar mais escassos ou impróprios para o uso em função da gestão não planejada ou desvinculada de uma visão sistêmica que deve permear as intervenções humanas no meio natural. $\mathrm{O}$ quadro abaixo relaciona as principais atividades humanas e os respectivos impactos que afetam o equilíbrio natural do ambiente. 
QUADRO 7: Atividades humanas e respectivos impactos ambientais em ambientes aquáticos.

\begin{tabular}{|c|c|c|}
\hline Atividade humana & Impacto nos ecossistemas aquáticos & Valores/serviços em risco \\
\hline $\begin{array}{l}\text { Construção de } \\
\text { represas }\end{array}$ & $\begin{array}{l}\text { Alteração do fluxo dos rios, transporte } \\
\text { de nutrientes e sedimentos, } \\
\text { intereferência na migração e } \\
\text { reproduçăo de peixes }\end{array}$ & $\begin{array}{c}\text { Habitats, pesca comercial e } \\
\text { esportiva, deltas e suas } \\
\text { economias }\end{array}$ \\
\hline $\begin{array}{l}\text { Construçăo de } \\
\text { diques e canais }\end{array}$ & $\begin{array}{c}\text { Destruição da conexăo do rio com as } \\
\text { áreas inundáveis }\end{array}$ & $\begin{array}{c}\text { Fertilidade natural das várzeas e } \\
\text { controles das enchentes }\end{array}$ \\
\hline $\begin{array}{c}\text { Alteração do canal } \\
\text { natural dos rios }\end{array}$ & $\begin{array}{c}\text { Danos ecológicos dos rios. Modificação } \\
\text { dos fluxos dos rios }\end{array}$ & $\begin{array}{l}\text { Habitats, pesca comercial e } \\
\text { esportiva. Produção de } \\
\text { hidroeletricidade e transporte. }\end{array}$ \\
\hline $\begin{array}{c}\text { Drenagem de áreas } \\
\text { alagadas }\end{array}$ & $\begin{array}{l}\text { Eliminação de um componente } \\
\text { fundamental dos ecossistemas } \\
\text { aquáticos }\end{array}$ & $\begin{array}{l}\text { Biodiversidade. Funções naturais } \\
\text { de filtragem e reciclagem de } \\
\text { nutrientes. Habitats para peixes e } \\
\text { aves aquáticas. }\end{array}$ \\
\hline $\begin{array}{l}\text { Desmatamento/uso } \\
\text { do solo }\end{array}$ & $\begin{array}{l}\text { Mudança de padrões de drenagem, } \\
\text { inibição da recarga natural dos } \\
\text { aquiferos, aumento da sedimentaçāo }\end{array}$ & $\begin{array}{l}\text { Qualidade e quantidade da água, } \\
\text { pesca comercial, biodiversidade } \\
\text { e controle de enchentes. }\end{array}$ \\
\hline $\begin{array}{l}\text { Poluição não } \\
\text { controlada }\end{array}$ & Prejuizo da qualidade da água & $\begin{array}{l}\text { Suprimento de água. Custos de } \\
\text { tratamento. Pesca comercial. } \\
\text { Biodiversidade. Saúde humana. }\end{array}$ \\
\hline $\begin{array}{c}\text { Remoção excessiva } \\
\text { de biomassa }\end{array}$ & $\begin{array}{c}\text { Diminuiçăo dos recursos vivos e da } \\
\text { biodiversidade }\end{array}$ & $\begin{array}{l}\text { Pesca comercial e esportiva. } \\
\text { Ciclos naturais dos organismos. }\end{array}$ \\
\hline $\begin{array}{l}\text { Introdução de } \\
\text { espécies exóticas }\end{array}$ & $\begin{array}{l}\text { Supressăo das espécies nativas. } \\
\text { Alteraçāo dos ciclos de nutrientes e } \\
\text { ciclos biológicos }\end{array}$ & $\begin{array}{c}\text { Habitats, pesca comercial. } \\
\text { Biodiversidade natural e } \\
\text { estoques genéticos. }\end{array}$ \\
\hline $\begin{array}{l}\text { Poluentes do ar } \\
\text { (chuva ácida) }\end{array}$ & $\begin{array}{c}\text { Perturbaçăo da composição química de } \\
\text { rios e lagos }\end{array}$ & $\begin{array}{c}\text { Pesca comercial. Biota aquática. } \\
\text { Recreaçăo. Saúde humana. } \\
\text { Aqricultura }\end{array}$ \\
\hline $\begin{array}{l}\text { Mudanças globais no } \\
\text { clima }\end{array}$ & $\begin{array}{l}\text { Alteração drástica do volume dos } \\
\text { recursos hídricos, dos padrōes de } \\
\text { distribuição da precipitação e } \\
\text { evaporaçăo, riscos de enchente }\end{array}$ & $\begin{array}{c}\text { Suprimento de água, transporte, } \\
\text { produçăo de energia elétrica, } \\
\text { produçăo agricola, pesca. }\end{array}$ \\
\hline $\begin{array}{c}\text { Crescimento da } \\
\text { populaçăo e padrōes } \\
\text { gerais do consumo } \\
\text { humano }\end{array}$ & $\begin{array}{c}\text { Aumento na pressăo para construção } \\
\text { de hidroelétricas, da poluição da água, } \\
\text { da acidificaçẵo de lagos e rios. } \\
\text { Modificaçăo do ciclo hidrológico. }\end{array}$ & $\begin{array}{l}\text { Praticamente todas as atividades } \\
\text { econômicas que dependem dos } \\
\text { serviços dos ecossistemas } \\
\text { aquáticos. }\end{array}$ \\
\hline
\end{tabular}

Fonte: TUNDISI, J. G. Água no século XXI: enfrentando a escassez. São Carlos: RIMA, IIE, 2005, p. 


\subsubsection{Bacia hidrográfica}

Bacia hidrográfica pode ser definida como uma área da superfície drenada por um rio principal e seus afluentes, composta por um conjunto de canais de escoamento interrelacionados, constituindo assim um sistema hierarquizado, cujos cursos menores drenam em direção a um canal principal. É um sistema dinâmico e aberto, pois recebem energia fornecida pela ação do clima e da tectônica local. Além disso, está sujeita às modificações que ocorrem ao longo dos divisores de água, devido aos processos erosivos, transportes e sedimentação com variância na quantidade de água a depender do tamanho da área que a bacia ocupa, do grau de precipitação e das perdas devidas à evapotranspiração e à infiltração.

Estudos realizados por GUERRA \& CUNHA (1966) mostram que as bacias hidrográficas estão interligadas por divisores topográficos, formando uma rede onde cada uma delas drena água, material sólido e dissolvido para uma saída comum ou ponto terminal que pode ser um outro rio, lago, reservatório ou oceano. As bacias se subdividem em canais cada vez menores da jusante para a montante. Os cursos iniciais que fluem diretamente do subsolo para formar a bacia são chamados cursos de primeira ordem. Esses se juntam e formam os de segunda ordem até que todos os tributários se unem num único rio principal.

Do ponto de vista do equilíbrio, a bacia hidrográfica subordina-se ao comportamento das condições naturais e da ação do homem, cuja ação, pode alterar leitos e canais. As causas naturais mais comuns são a erosão potencial das encostas, a produção de sedimentos devido às fortes chuvas que provocam o assoreamento e consequentemente uma diminuição da profundidade da calha do rio, cujo canal, em busca do seu equilíbrio, tende a alargar as margens através dos processos erosivos. No entanto esses processos naturais se intensificam com a ação não planejada do homem: desmatamento indiscriminado, ocupação desordenada em áreas de bacias hidrográficas, mau uso da terra e substituição das matas ciliares, exploração de aluviões, queimadas e intensa mecanização são alguns exemplos que culminam na degradação da área de drenagem.

GUERRA (1993) define os vales fluviais como uma área de depressão alongada (longitudinal), formada por um ou mais talvegues e duas vertentes, também como planície à beira do rio ou várzea. Essa planície recebe e acomoda o volume acrescido de água nas enchentes.

Estudos feitos por PIRES, SANTOS, DEL PRETTE (2002) mostram que as condições geomorfológicas da planície de inundação podem influenciar em sua produtividade biológica. 
Nessas condições, os sedimentos oriundos da região do compartimento de terra firme podem ser responsáveis pelo assoreamento precoce das áreas de planícies de inundações. O fenômeno da erosão contribui para o aumento do processo de sedimentação e para mudança no regime que modifica o leito e o alinhamento dos rios. Muitos estudiosos atribuem a causa da erosão e do assoreamento à abertura de áreas destinadas à agricultura e à pecuária ou ao uso inadequado dos solos. Isso inclui a destruição de áreas permanentes (matas de encostas e matas ciliares) e ampliação de áreas urbanas.

Uma vez assoreado, todas as condições naturais do rio serão alteradas, o regime de água poderá ser diminuído, bem como a velocidade da corrente. Este é um processo natural, no entanto, em decorrência de todo manejo inadequado do solo, tem sido um fator que antecipa a fase de maturidade e consequentemente também a senilidade do rio. Quando o assoreamento é intenso e associado a outras consequências da ação humana, como o despejo de esgotos, e resíduos químicos, como o mercúrio, o qual é muito utilizado por garimpeiros, e agroquímicos, empregados na agricultura, os rios podem até mesmo ser extintos e quando isso não ocorre suas águas ficam impróprias para o consumo humano.

\subsubsection{Impactos ambientais}

A história das primeiras formas de impacto ambiental é tão antiga quanto à descoberta da técnica pela qual o homem pôde intervir no meio. Dessa forma, ele pode aproveitar os recursos naturais que estavam ao seu alcance, modificando o seu meio de acordo com suas necessidades. Sendo assim, ele se torna o principal responsável pelas mudanças mais significativas no meio natural. Frente a isso se vê que as intervenções realizadas pelo homem comportam aspectos negativos e quando são insuficientemente controlados tendem a se agravar (TRICART, 1978).

Na resolução CONAMA n.001 de 23 de Janeiro de 1986, art. $1^{\circ}$, impacto ambiental é considerado

Qualquer alteração das propriedades físicas, químicas e biológicas do meio ambiente, causada por qualquer forma de matéria ou energia resultante das atividades humanas, os, que, direta ou indiretamente afetam: a saúde, a segurança e o bem-estar da população; as atividades sociais e econômicas; a biota. As condições estéticas e sanitárias do meio ambiente, a qualidade dos recursos ambientais.

A partir desta definição é possível considerar que o sistema ambiental possui uma dimensão ampla, ao contemplar aspectos sociais, econômicos e naturais. Os impactos são 
categorizados e valorados em classes conceituais, não numéricas, de acordo com as diretrizes da Resolução Conama 001/86 (IBAMA 1992), apresentadas a seguir.

Quadro 8: Impacto Ambiental de acordo com as diretrizes da resolução CONAMA 001/86

\begin{tabular}{|c|c|}
\hline Magnitude & $\begin{array}{l}\text { A magnitude é definida pela extensão do efeito daquele tipo de ação sobre a } \\
\text { característica ambiental, em escala espacial e temporal. É classificada como } \\
\text { alta, média ou baixa. }\end{array}$ \\
\hline Significância & $\begin{array}{l}\text { Indica a importância do impacto no contexto da análise. É classificada como } \\
\text { alta, média ou baixa. }\end{array}$ \\
\hline Natureza & $\begin{array}{l}\text { Indica se o impacto ambiental é positivo ou negativo, da seguinte forma: } \\
\text { impacto positivo (ou benéfico) - quando a ação resulta na melhoria da } \\
\text { qualidade de um fator ou parâmetro ambiental; impacto negativo (ou } \\
\text { adverso) - quando a ação resulta em um dano à qualidade de um fator ou } \\
\text { parâmetro ambiental. }\end{array}$ \\
\hline Forma & $\begin{array}{l}\text { Indica se o impacto ambiental é direto ou indireto, da seguinte maneira: } \\
\text { impacto direto - resultante de uma simples relação de causa e efeito; } \\
\text { impacto indireto - resultante de uma reação secundária em relação à ação, } \\
\text { ou quando é parte de uma cadeia de reações. }\end{array}$ \\
\hline Prazo de ocorrência & $\begin{array}{l}\text { Indica se o impacto ambiental ocorre de forma imediata, de médio ou longo } \\
\text { prazo, da seguinte forma: impacto imediato - quando ao impacto ambiental } \\
\text { (efeito) ocorre no mesmo momento em que se dá a atividade transformadora } \\
\text { (causa); impacto de médio prazo - quando ao impacto ambiental (efeito) } \\
\text { ocorre em médio prazo, a partir do momento em que se dá a atividade } \\
\text { transformadora (causa); impacto de longo prazo - quando ao impacto } \\
\text { ambiental (efeito) ocorre em longo prazo, a partir do momento em que se dá } \\
\text { a atividade transformadora (causa). }\end{array}$ \\
\hline Constância/duração & $\begin{array}{l}\text { Indica se o impacto ambiental em questão é temporário, permanente ou } \\
\text { cíclico, da seguinte forma: impacto temporário - quando o efeito (impacto } \\
\text { ambiental) tem duração determinada; impacto permanente - quando, uma } \\
\text { vez executada a atividade transformadora, o efeito não cessa de se } \\
\text { manifestar num horizonte temporal conhecido; impacto cíclico - quando o } \\
\text { efeito se manifesta em intervalos de tempo determinados. }\end{array}$ \\
\hline Abrangência & $\begin{array}{l}\text { Este parâmetro indica se o impacto ambiental é local, regional ou } \\
\text { estratégico, segundo as seguintes definições: impacto local - quando a ação } \\
\text { afeta apenas o próprio sítio e suas imediações; impacto regional - quando o } \\
\text { impacto se faz sentir além das imediações do sítio onde se dá a ação; } \\
\text { impacto estratégico - quando o componente ambiental afetado tem relevante } \\
\text { interesse coletivo ou } \\
\text { nacional. }\end{array}$ \\
\hline
\end{tabular}




\begin{tabular}{|l|l|}
\hline Reversibilidade & $\begin{array}{l}\text { Indica se o impacto ambiental em questão é reversível ou irreversível, } \\
\text { seguindo as seguintes definições: impacto reversível - quando o fator ou } \\
\text { parâmetro ambiental afetado, cessada a ação, retorna às suas condições } \\
\text { originais; impacto irreversível - quando, uma vez ocorrida a ação, o fator ou } \\
\text { parâmetro ambiental afetado não retorna às suas condições originais em um } \\
\text { prazo previsível. }\end{array}$ \\
\hline $\begin{array}{l}\text { cumulatividade e } \\
\text { sinergia }\end{array}$ & $\begin{array}{l}\text { Se houver efeitos cumulativos e/ou sinérgicos, estes serão destacados na } \\
\text { descrição do impacto ambiental, indicando sua magnitude e relações. } \\
\text { Seguem as respectivas definiçôes: }\end{array}$ \\
$\begin{array}{l}\text { Cumulatividade: quando o impacto deriva da soma de outros impactos ou de } \\
\text { cadeias de impacto que se somam, porém contíguo, num mesmo sistema } \\
\text { ambiental. Impacto no meio ambiente resultante do impacto incremental da } \\
\text { ação quando adicionada a outras ações passadas, presentes e futuras, } \\
\text { razoavelmente previsíveis (MAGRINI, 1990). }\end{array}$ \\
$\begin{array}{l}\text { Sinergia: é o efeito ou força ou ação resultante da conjunção simultânea de } \\
\text { dois ou mais fatores, inclusive de outros empreendimentos (caso das usinas } \\
\text { de Angra 1 e 2, situadas no mesmo sítio: a CNAAA), de forma que o } \\
\text { resultado é superior à ação dos fatores individualmente, sob as mesmas } \\
\text { condições. Em outros termos, a associação de tais fatores não somente } \\
\text { potencializa a sua ação como, ainda pode produzir um efeito distinto } \\
\text { (MAGRINI, 1990). }\end{array}$ \\
\hline
\end{tabular}

Fonte: IBAMA, 1992

Os impactos da ação do homem recaem sobre a natureza de forma mais intensa depois que o mundo entra no processo de desenvolvimento urbano e industrial sem ter preparado previamente o meio natural para receber os frutos desse processo: esgotos industriais, emissão de gases na atmosfera, ocupação de extensas áreas de vegetação. No Brasil a devastação tem início com o processo de colonização, mas é a partir da década de 50 que a natureza será mais acarretada com o processo de desenvolvimento: intensa urbanização da região Sudeste, projetos de desenvolvimento para a Amazônia e para o Nordeste, instituição da fronteira agrícola no cerrado brasileiro com a cultura da soja (ROSS, 2003). O poder público, após séculos de omissão frente aos projetos desenvolvimentistas do ponto de vista econômico, tem procurado intervir através de uma legislação específica.

\subsubsection{Planejamento ambiental}

O planejamento ambiental pode ser entendido como uma forma de implementar uma política de uso racional dos recursos naturais, amenizando os efeitos da intervenção humana 
no ambiente natural. Tem como centro de preocupação os homens como seres sociais. É realizado para melhorar a prática de apropriação dos recursos naturais, evitando usos inadequados tanto no âmbito da exploração quanto no destino dos resíduos e se fundamenta no conhecimento da realidade socioeconômica da comunidade, objeto de análise e do atual uso da terra e dos recursos naturais (ROSS, 2003). Deve prever e indicar mudanças no uso da terra e na exploração de fontes aceitáveis para as comunidades locais e regionais, observando de forma holística e sistêmica as potencialidades e fragilidades do meio ambiente, definindo e espacializando ocupações, ações e atividades de acordo com suas características, para que assim, seja evitado o esgotamento dos recursos (SANTOS, 2004, p. 28). A atividade de planejamento é uma prática fundamentalmente política, seja em suas diferentes formas, aspectos ou níveis.

O poder público através das políticas públicas é o maior agente responsável por direcionar as formas de uso e ocupação do solo no país. Nas últimas décadas o planejamento ambiental tem ocupado com maior frequência a agenda nos debates e assembleias políticas desde a esfera federal até o municipal. Uma diversidade de leis e decretos vigentes tem proposto que as práticas econômicas sejam planejadas observando a exploração racional dos recursos naturais.

Um dos instrumentos legais que tem favorecido o planejamento ambiental no Brasil é a Política Nacional do Meio Ambiente (lei 6938/81) que estabeleceu o Zoneamento Econômico Ecológico regulamentado pelo Decreto Federal 4229/02. O artigo $2^{\circ}$ apresenta a seguinte definição

instrumento de organização do território a ser obrigatoriamente seguido na implantação de planos, obras e atividades públicas e privadas, estabelece medidas e padrões de proteção ambiental destinados a assegurar a qualidade ambiental dos recursos hídricos e do solo e a conservação da biodiversidade, garantindo o desenvolvimento sustentável e a melhoria das condições de vida da população.

Nesta perspectiva, o ZEE se configura como um importante instrumento para subsidiar a formulação de políticas públicas territoriais da União, Estados e Municípios, dispondo de um mecanismo integrado de diagnóstico sobre o meio físico, biótico, econômico e que contemple as reais necessidades da comunidade, contribuindo para que o sistema de planejamento oriente os investimentos do governo e a prática da sociedade civil em relação ao uso dos recursos naturais, segundo as especificidades das áreas definidas como zonas homogêneas e tratadas como unidades de planejamento (ROSS, 2009). 
A prática do Zoneamento Ambiental pressupõe um estudo aprofundado das potencialidades dos recursos naturais que passa pelo levantamento de todos os componentes do estrato geográfico que dão suporte à vida animal (solo, relevo, rochas e minerais, águas, clima, flora e fauna) bem como, das práticas sociais e econômicas para enfim, avaliar as fragilidades. Este estudo, de acordo com ROSS (2009, p. 150), deve ser considerado no planejamento territorial ambiental, segundo o qual o ambiente é analisado na perspectiva da Teoria dos Sistemas, pois pressupõe que as trocas de energia e matéria que ocorrem na natureza se processam por relações de equilíbrio dinâmico. É um instrumento lógico que investiga a natureza de forma integrada, analisando as intervenções do homem nos diversos componentes da natureza. A abordagem Sistêmica implica em estudos interdisciplinares que permitem entender a dinâmica da natureza de forma complexa.

No planejamento ambiental a proposição teórico-metodológica apresentada pela Teoria dos Sistemas contempla os anseios de desenvolvimento que considera a preservação e a recuperação dos ambientes naturais, afetados pelas intervenções humanas. TRICART (1977, p.33) defende a importância de se adotar tal concepção na questão do uso e exploração dos recursos naturais, pois

a gestão dos recursos ecológicos deve ter por objetivo a avaliação do impacto da inserção da tecnologia humana no ecossistema. Isso significa determinar a taxa aceitável de extração dos recursos, sem degradação do ecossistema, ou determina quais as medidas que devem ser tomadas, para permitir uma extração mais elevada sem degradação.

\subsubsection{Planejamento ambiental no Brasil}

A organização espacial do Brasil reflete a forma como o colonizador europeu se apossou e dominou o território sob a bandeira da conquista e da exploração. Toda a prática destes povos objetivava expandir o domínio e consequentemente a retirada desenfreada de todos os recursos que viessem atender às necessidades do mercado externo. Os ciclos econômicos que se desenvolveram no Brasil são uma resposta aos anseios capitalistas. As riquezas tropicais abundantes no território brasileiro foram fonte de riqueza do colonizador durante o período de dominação e das elites que se consolidaram posteriormente e seguiram o modelo estrangeiro de dominação.

Foram séculos de exploração e de omissão do poder público frente à devastação da natureza, antes o Estado assume o papel de "viabilizador da conquista, de indutor do povoamento das terras, de dotador de equipamentos, de gestor da ocupação do solo" (MORAES, 1999, p.3). O modelo de desenvolvimento a ser perseguido e imitado das nações 
poderosas capitalistas valorizava a mata no chão. Extensões de terras cobertas por floresta era sinônimo de atraso econômico, pois inviabilizava o plantio de culturas que atendiam aos interesses externos, ou impedia a exploração de minérios. Com o surto da economia cafeeira, a partir de 1850 , estima-se que 510.000 hectares de matas foram sacrificados. A madeira quase que em sua totalidade era queimada ou abandonada, não tendo a menor utilização econômica. A floresta precisava ser conquistada e dominada a qualquer custo. A mentalidade imediatista que imperava na época responsabilizava as matas pela insalubridade das terras (VICTOR et al, 2005, p.12).

Nos séculos seguintes, o crescimento econômico almejado ainda estava pautado na exploração dos recursos naturais ditado pelos interesses do mercado externo, com pouca intervenção do poder público, sem um planejamento estratégico que definisse os rumos da economia, descomprometido com as necessidades da população e que visava apenas o acúmulo de capitais. O planejamento torna-se prática política de forma mais efetiva somente após os anos de 1930 com o governo de Getúlio Vargas, que priorizou investimentos em infraestrutura e na indústria de base. É desse período o Código das Águas (1934), importante instrumento legal para gerenciar os usos múltiplos das águas no país. O governo Juscelino Kubistchek adotou o planejamento como forma de fomentar o desenvolvimento, mas através de um modelo econômico dependente que exigiu do Estado uma intervenção que garantisse maior abertura para o capital estrangeiro e uma política dirigida a privilegiar ainda mais o grande capital. Nesse período conferiu-se um intenso desenvolvimento econômico através da abertura de estradas e incentivo à instalação de empresas estrangeiras no Brasil (ROSS, 2008).

Um planejamento pautado na integração econômica e social torna-se plano de governo no período de 1961-1964 com João Goulart. A conjuntura social e econômica do país exigia as reformas de base. Nas décadas seguintes, sob o comando dos militares, o desenvolvimento econômico continuou a ser perseguido, buscando maior controle dos recursos naturais. A criação do Código florestal (1965) passou a estabelecer restrições à exploração das espécies vegetais, sobretudo madeiras, além de estabelecer critérios para o desmatamento. Apesar de já existir nessas décadas uma legislação que buscava disciplinar a exploração dos recursos naturais, os projetos desenvolvimentistas avançavam pela floresta amazônica, abrindo novas estradas, buscando uma maior integração econômica dessa região com as demais regiões do Brasil. Sobre o modelo de desenvolvimento econômico adotado no Brasil, ROSS (1998, p. 97) afirma que

o desenvolvimento econômico brasileiro das últimas décadas, baseado exclusivamente em um processo de planejamento econômico, teve como 
saldo positivo o crescimento econômico e tecnológico do país, mas com efeitos perversos no campo social e ambiental, colocando à margem da economia de mercado grande parcela da população, e intensificando os processos de degradação ambiental nas áreas urbanas e rurais.

A falta de planejamento na utilização dos recursos naturais ao longo do processo de colonização e exploração econômica do Brasil reflete suas condições nos dias atuais: o esgotamento dos solos, a redução das florestas em parques e reservas, o colapso dos reservatórios de água e a poluição dos diferentes corpos d'água. Todos esses fatores têm forçado o poder público a pôr em prática as leis vigentes que se consolidaram ao longo das últimas cinco décadas e a fiscalizar o seu exercício.

A sociedade civil organizada tem alcançado maior participação em projetos e conselhos que acompanham os múltiplos usos que se faz dos recursos naturais, porém "num país construído na apropriação de espaços, onde governar é abrir estradas, a ideia de natureza como valor em si tem dificuldade em se enraizar nas práticas sociais”. (MORAES, 1999, p. 49). O autor ainda afirma que o Brasil dispõe de instrumentos sofisticados de planejamento e gestão ambiental, nos quais se contemplam a espacialização de processos, que preveem a participação de atores locais das áreas de ação, com um quadro legislativo bem discriminado, com metodologias e propostas bem definidas, mas a efetivação das ações e metas ainda está muito aquém do que se é esperado pela dinâmica territorial e populacional do país.

A mentalidade de lucro imediatista persiste na prática das grandes corporações que atuam na exploração dos recursos naturais. Os EIAs/RIMAs são elaborados por empresas descompromissadas com as demandas do meio ambiente, com o objetivo apenas de atender as exigências da lei, e o patrimônio natural do país continua sendo exaurido, sem que seja gerada uma riqueza que corresponda minimamente ao dano causado, principalmente para a população local que sobrevive da exploração limitada dos recursos disponíveis na região (MORAES, 1999). A natureza tem apresentado sinais de exaustão, haja vista a intensidade e frequência de eventos naturais que provocam movimentação de massa, baixa produtividade dos solos, enchentes, irregularidades das chuvas e que repercutem na dinâmica social, sobretudo para os mais pobres que ocupam áreas de risco.

O avanço científico multidisciplinar tem contribuído para um conhecimento aprofundado das potencialidades, fragilidades e possibilidades de recuperação dos ambientes naturais degradados, discriminados em relatórios técnicos de impactos ambientais. O acúmulo de conhecimentos nessa área ao longo do tempo repercutiu nas legislações que disciplinam o uso e a exploração dos recursos naturais no Brasil. Desde a criação do Código das águas até a 
Resolução Conama verifica-se que o poder público, enquanto principal agente promotor da organização territorial no Brasil, avançou para a prática do planejamento, observando a indissociabilidade entre desenvolvimento econômico e social, ainda que com muitos desafios a serem superados.

A preocupação com as questões ambientais acentuou-se a partir de 1960. Nesse período os movimentos ambientalistas ascenderam principalmente na Europa Ocidental, ganhando espaço na mídia. Após a Conferencia de Estocolmo (1972) aumentaram as pressões para que as questões ambientais fossem consideradas de forma mais explícita no plano político, principalmente no Brasil, e criaram-se secretarias direcionadas para o meio ambiente com a atuação de corpos técnico-científicos especializados na fiscalização, no controle de emissão e tratamento de resíduos sólidos, líquidos e gasosos e culminou na década de 80 com a instituição da Política Nacional do Meio Ambiente (lei 6938/81), um marco legal para todas as políticas públicas de meio ambiente a serem desenvolvidas (ROSS, 2010, p. 297).

A Política Nacional do Meio Ambiente (lei 6938/81) cria o SISNAMA e CONAMA, abrindo questões ambientais para o debate por representante do poder político e entidades da sociedade civil, colocando em pauta a interdisciplinaridade da questão ambiental, sobretudo o planejamento ambiental passou a integrar as políticas públicas, deixando de ser consequência destas. A resolução CONAMA 001, que criou a obrigatoriedade dos estudos de impactos ambientais, contribuiu para que o planejamento ambiental se tornasse uma política, principalmente a partir da década de 1990 quando este instrumento foi incorporado aos planos diretores municipais, o que possibilitou um conhecimento mais contundente sobre a qualidade de vida, desenvolvimento sustentável, sociedade e meio ambiente, promovidas pela preocupação com o ser humano (SANTOS, 2004).

De acordo com Resolução 01/86 do Conama, qualquer licenciamento de projetos de intervenção no meio ambiente deve ser precedido de um estudo de avaliação de impactos ambientais (EIA), culminando com a elaboração do Relatório de Impacto Ambiental (RIMA). Os EIAs-RIMAs devem estabelecer soluções técnico-científicas que possam diminuir os efeitos dos impactos adversos previamente identificados e qualificados.

A lei 9.985 de 18 de julho de 2000 institui o Sistema Nacional das Unidades de Conservação. Esta se constitui num conjunto de diretrizes e procedimentos oficiais que possibilitam às esferas governamentais (federal, estadual e municipal) e da iniciativa privada a criação, implantação e gestão das Unidades de Conservação, cujos objetivos específicos se diferenciam quanto à forma de proteção e usos permitidos: Unidades de Proteção Integral (PI) 
- tem por finalidade preservar a natureza, admitindo-se apenas o uso indireto dos recursos naturais; Unidades de Uso Sustentável (US) - concilia a conservação da natureza com o uso sustentável de parte dos recursos naturais.

A constituição Federal em seu artigo 225 sinaliza para a responsabilidade do poder público de preservar e defender o meio ambiente e isso se materializa na definição de espaços territoriais e seus componentes a serem protegidos. De acordo com o IBAMA, a criação das Unidades de Conservação por ato do poder público deve ser amparada em estudos técnicocientíficos, precedidos de consulta pública, com exceção da Estação Ecológica ou Reserva Biológica. Os instrumentos legais que dispõem sobre as Unidades de Proteção Integral propõem a criação de um conselho Consultivo, constituído por representantes de órgãos públicos, de representantes da sociedade civil, por proprietários de terra localizados em refúgio de vida silvestre ou movimento natural e das populações tradicionais residentes de acordo com a disposição do regulamento. Todas as Unidades de Conservação devem dispor de um plano de manejo. Este deve abranger a área da Unidade, sua zona de amortecimento e os corredores ecológicos, incluindo medidas com o fim de promover sua integração à vida econômica e social das comunidades vizinhas (SANTOS, 2004). 


\section{Município de Juquitiba: uma reserva de mata atlântica}

4.1 Fatores geomorfológicos que contribuíram para a formação da mata atlântica

As condições naturais que propiciaram a evolução da Floresta Atlântica são marcadas por muitos eventos geológicos. O embasamento do solo brasileiro é constituído por rochas paleozoicas, denominadas de Crato-Sulamericano, sobre o qual se sobrepõem rochas sedimentares depositadas ou oriundas dos processos erosivos ou eruptivos decorrentes de episódios de vulcanismos que resultaram em vastos derrames de lavas. O solo da Mata Atlântica é resultado destes dois eventos geológicos.

$\mathrm{Na}$ era Paleozoica o Crato-Sulamericano sofreu lentos movimentos regionais ascendentes e descendentes que permitiram o avanço dos mares rasos sobre grandes áreas continentais, dando origem às unidades geotectônicas denominadas de Bacias. A Mata Atlântica, originalmente evoluiu sobre as Bacias do Paraná e do Parnaíba. Nessas unidades acumularam sedimentos predominantemente marinhos, atingindo grandes espessuras. Entre os períodos Devoniano e final do Carbonífero-Permiano, o acúmulo de rochas sedimentares se intensificou. Posteriormente esses sedimentos foram recobertos por outras rochas, algumas provenientes de derrames de lavas. Os sedimentos Paleozoicos afloraram à superfície do terreno em faixas estreitas nas bordas leste e oeste da Bacia. Os sedimentos devonianos afloraram na parte Ocidental, erodidos em encostas mais íngremes, correspondente ao segundo Planalto Paranaense e exibem canhões (canyons), pequenas cachoeiras, campos e Matas das Araucárias. Os sedimentos Carbo-Permianos possuem litologias variadas e afloraram em longa faixa que se estendem de São Paulo ao Rio Grande do Sul.

No final do Carbonífero ou início do Permiano ocorreu uma intensa glaciação que deixou marcas na história geológica da Bacia do Paraná: sulcos deixados pelo movimento das geleiras em rochas duras, varvitos (tipo de rocha sedimentar glacial estriada), tilitos (sedimentos não consolidados de origem glacial e blocos de rochas transportadas pelo gelo) são encontradas em diversas localidades.

Ao final do Permiano e durante o Triásico toda a região da Bacia do Paraná foi submetida a um soerguimento e a um progressivo ressecamento, que culminou, no final do Triásico e início do Jurássico, com a formação de uma imensa área desértica, conhecida como Deserto de Botucatu. A transição do Jurássico para o Cretáceo é marcada pela separação do 
supercontinente Gondwana: placa africana que se separou da sul-americana. Episódios de vulcanismos e tectonismos manifestaram-se em vários pontos do território do Brasil. A Bacia do Paraná foi coberta por imensos derrames de lavas basálticas sobrepondo-se às áreas e a demais sedimentos do Deserto de Botucatu. Ao longo do litoral, onde se deu a separação do território africano, o vulcanismo favoreceu a formação de pequenas bacias localizadas decorrentes de falhamentos que originaram fossas tectônicas preenchidas por sedimentos. As bacias basálticas se solidificaram e, submetidas a diversas modalidades de erosão, deram origem ao Terceiro Planalto Paranaense e ao Planalto Gaúcho.

Durante o Cretáceo superior, os derrames de lavas basálticas foram cobertos por sedimentos de origem não marinha, constituídos principalmente de arenitos, conhecidos como grupo Bauru e Formação Caiuá. A sedimentação Bauru recobriu grandes áreas da Bacia do Paraná e encontra-se amplamente reduzida pela erosão. Os arenitos de formação Caiuá ocorrem no Oeste Paulista, que foi revestido por vigorosa Floresta Estacional Semicaducifólia dilapidada na sua quase totalidade e desgastada pelos processos erosivos.

Os falhamentos iniciados no Cretáceo e durante o Período Terciário deram origem às montanhas costeiras do sistema Serra do Mar - Mantiqueira. Nessas regiões encontram-se porções da Mata Atlântica protegidas pela topografia. No período Cenozoico, o Crato Sulamericano manteve-se estável ao longo do litoral brasileiro, apenas no Mioceno, essa região sofreu um rebaixamento temporário, seguido de uma nova fase de lento soerguimento e elevação de sedimentos marinhos para a região. Estas condições afetadas pelos processos erosivos decorrentes das condições climáticas, alternadamente úmidas e áridas, que predominaram nos últimos milhões de anos, deram origem ao relevo do território brasileiro, que ao final do terciário já delineava as feições presentes, inclusive as redes de drenagem. $\mathrm{O}$ término do período Glacial e início do Holoceno caracterizaram-se por regimes de chuvas mais intensas e regulares nas regiões tropicais e subtropicais, propiciando a expansão das florestas (CÂMARA, 1991).

Atualmente a Bacia do Paraná encontra-se profundamente alterada pelos projetos de geração de energia elétrica. As barragens construídas para este fim alteraram o regime dos rios (a modificação da vazão gera o acúmulo de sedimentos alterando as condições de turbidez).

As características do relevo apresentam evidências que se relacionam com o clima úmido e chuvas bem distribuídas. Esse fato refletiu a composição da flora e da fauna. Outro fator determinante para a biodiversidade da Mata Atlântica foi o período glacial que 
contribuiu para o rebaixamento do nível do mar. As extensas áreas expostas foram colonizadas pela biota. De acordo com Ab'Saber, 1980 (apud CÂMARA,1991) a alternância de períodos secos e úmidos do Quaternário possibilitou a formação de Refúgios Ecológicos. Nos períodos mais secos e frios, a cobertura arbórea deve ter se fragmentado, restringindo às áreas onde as condições geográficas, pedológicas e hidrológicas permitiram sua continuação.

4.2 Características físicas do município

O município de Juquitiba possui uma área de $521,598 \mathrm{~km}^{2}$. Seus limites são Ibiúna a oeste e norte, São Lourenço da Serra e Embu-Guaçu a nordeste, São Paulo a leste, Itanhaém a sudeste, Pedro de Toledo e Miracatu a sul. 


\section{LOCALIZAÇÃO DO MUNICÍPIO DE JUQUITIBA}
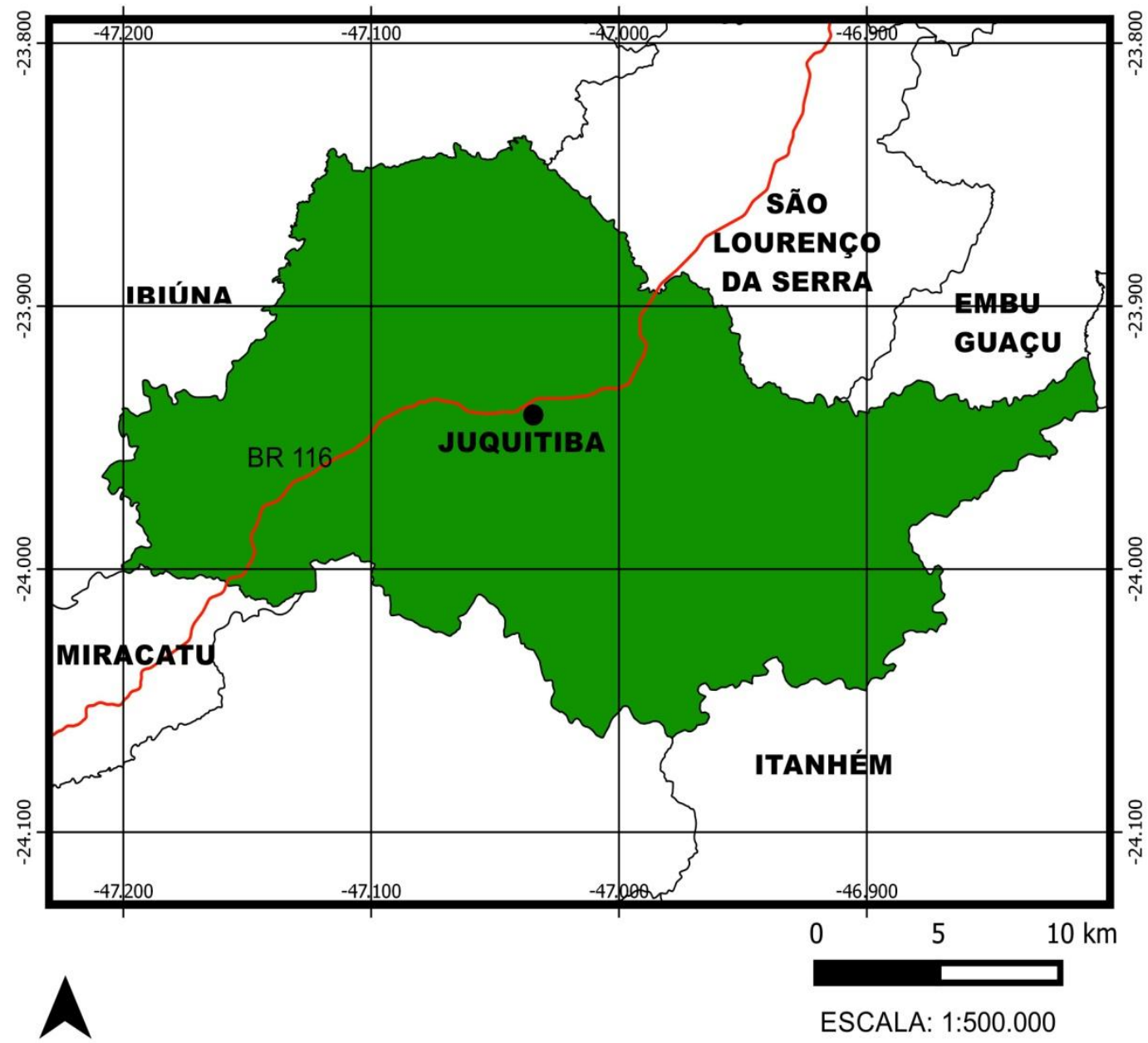

ESCALA: 1:500.000

SISTEMA DE COORDENADA GEOGRÁFICA

FUSO: 23 $S$ - DATUM HORIZONTAL: SIRGAS 2000

ELABORAÇÃO: GISELIA PINHEIRO DOS REIS, 2016

Figura 2: Localização do município de Juquitiba - SP 
Juquitiba é um termo de origem tupi que significa "Terra de muitas águas". Este topônimo está relacionado com as condições naturais do município que abriga em seu território grande quantidade de nascentes, rios, riachos, represas, cachoeiras, além de ser uma região chuvosa. Os principais rios que se encontram no município são: São Lourenço, Juquiá, Ribeirão das Capivaras, Ribeirão das Laranjeiras, Ribeirão dos Cuiabás e Cachoeira do França. O município possui ainda longos trechos de Mata Atlântica preservada, sendo que $67 \%$ do seu território é coberto por reservas florestais intocadas, o que faz o município ter grande valor ambiental. O clima predominante é Subtropical com Verão pouco quente e chuvoso e Inverno ameno e subseco. A média de temperatura anual é em torno dos $18^{\circ} \mathrm{C}$, sendo o mês mais frio julho (Média de $13^{\circ} \mathrm{C}$ ) e o mais quente fevereiro (Média de $22^{\circ} \mathrm{C}$ ). $\mathrm{O}$ índice pluviométrico anual fica em torno de $1300 \mathrm{~mm}$. É região montanhosa, a altitude média é de $685 \mathrm{~m}$. O ponto mais alto fica no Bairro das Laranjeiras $(900 \mathrm{~m})$ e o mais baixo no Bairro do Engano (550m).

\subsection{Processo de formação e ocupação do território de Juquitiba}

As condições climáticas do território (região submetida a constantes geadas no inverno) limitaram a inserção do município de Juquitiba nas atividades econômicas que

projetou São Paulo no cenário mundial da economia cafeeira e açucareira. A ocupação do território está relacionada a um aldeamento indígena surgido no século XVI. O povoamento intensificou-se com a construção da capela em homenagem a Nossa Senhora das Dores (padroeira da cidade).

No início do século XX, a população era composta em sua maioria por lavradores que viviam da cultura de subsistência e da criação de suínos. O excedente da produção era comercializado em Itapecerica da Serra e no bairro de Santo Amaro na cidade de São Paulo. O transporte da mercadoria era realizado através de tropas de muares. O trajeto íngreme dificultava o percurso, demandando dias para se completar. Os tropeiros pernoitavam com os animais em diversos pousos existentes, como o atual "Paiol do Meio".

Nesse mesmo período, o engenheiro Henrique Boccolini projetou uma ferrovia que deveria ligar a capital de São Paulo a Curitiba - Paraná, sendo que seu primeiro trecho seria de São Paulo a Santo Antonio do Juquiá, atual Juquiá. O projeto não foi levado adiante por falta de capital para a execução da obra. Esta região não despertava interesse econômico porque suas condições naturais não favoreciam a exploração do café. Esse mesmo projeto foi retomado na década de 1950, mas não prosperou devido aos rumos da política 
desenvolvimentista do governo de Juscelino Kubitschek, que priorizou o setor automobilístico em detrimento do ferroviário. O traçado original da ferrovia foi utilizado para a construção da rodovia, atual BR 116 ou Rodovia Federal Regis Bittencourt.

A construção dessa rodovia foi precedida da abertura de uma estrada pela Companhia Siderúrgica, que permitiu o tráfego de caminhões que transportavam madeira e carvão e contribuiu para maior integração do município com as demais regiões vizinhas. Foi também essa rodovia que trouxe significativo desenvolvimento econômico para a região, oferecendo condições para o município pleitear sua emancipação política-administrativa. Juquitiba tornou-se um município independente de Itapecerica da Serra em 28 de fevereiro de 1964 (IBGE, 2015).

4.4 Atividades econômicas e impactos ambientais no município de Juquitiba

As atividades relacionadas ao turismo contribuem significativamente para 0 desenvolvimento econômico do município. Os empreendimentos que se desenvolvem na região exploram o seu potencial hídrico com atividades de pesca, rafting, canoagem e suas belezas cênicas. As riquezas naturais agregadas à condição de proximidade da capital têm contribuído para que grandes empreendimentos imobiliários sejam implantados na região, principalmente no ramo de hospedagem, o que ocasiona uma ocupação irregular e desordenada do solo e provoca alterações significativas na paisagem.

Segundo o IBGE (2002), as condições naturais do munícipio são afetadas diretamente pelo despejo de resíduos industriais, esgoto doméstico, resíduos sólidos. A contaminação do solo acontece por chorume e sumidouros. De acordo com relatórios técnicos do DAEE, o município possui apenas $80 \%$ de atendimento de esgotamento sanitário e, apesar da existência do serviço de coleta de resíduos, não há programas de separação do lixo e de recicláveis considerando que as práticas da reciclagem e de reaproveitamento de materiais, além da diminuição da própria quantidade de resíduos destinados aos aterros sanitários, são condições necessárias para a diminuição dos impactos ambientais no município.

Os dados do IBGE (2010) revelam ainda o crescimento da população que ocupa áreas irregulares principalmente em cursos d'água e em áreas de lençóis subterrâneos, ocasionando a degradação de mata ciliar e a desfiguração da paisagem. Nas últimas décadas o município apresentou crescimento urbano desordenado, principalmente nas Áreas de Proteção Ambiental, como é o caso do bairro Jardim das Palmeiras, que constitui um dos aglomerados 
urbanos do município e que é o único planejado de acordo com a legislação municipal $\mathrm{n}^{\circ} 22$ de 1969, mas que não conseguiu conter o avanço de moradias irregulares às margens do Ribeirão dos Urus (braço do Rio São Lourenço). Estas formas de ocupação são uma tendência do crescimento urbano desordenado, que pressiona a população de baixa renda a ocupar áreas de risco, o que acarreta perdas humanas nos períodos intensos de chuva, além de prejuízos ambientais.

A economia do município também é influenciada pelas ativiades rurais. Estudos realizados pelo DAEE demostram que $22,3 \%$ da população vive no campo. As principais atividades desenvolvidas estão relacionadas no quadro abaixo, bem como sua abrangência no município em hectares:

Quadro 9: Uso e ocupação do solo no município de Juquitiba

\section{TIPO DE CULTURA}

PASTAGENS

CULTURAS TEMPORÁRIAS

FRUTICULTURA

SILVICULTURA

AGRICULTURA

\section{HECTARES OCUPADOS}

348

64

7

3138

71

Fonte: DAEE e Relatório de Situação dos Recursos Hídricos da UGRHI 11, 2008

\subsection{Sistema produtor São Lourenço}

Com a crise hídrica que se estabeleceu no Estado de São Paulo, e que tem atingido grandes proporções principalmente com o colapso do sistema Cantareira que abastece a região Metropolitana de São Paulo, tem-se forçado o poder público, junto com a empresa responsável pelo saneamento básico e abastecimento de água, a planejar novas alternativas para superá-la. Tornou-se público o projeto Sistema Produtor São Lourenço que visa a retirada da água da foz do rio São Lourenço em Juquitiba para complementar o abastecimento da Grande São Paulo. Atendendo à legislação ambiental, este projeto já conta com o RIMA (Relatório de Impacto Ambiental) desde março de 2011.

O gerenciamento dos recursos hídricos ocorre sob a vigência da lei estadual de proteção aos mananciais. O território do município é 100\% protegido por esta lei e atualmente 
sofre intervenção direta do Estado junto com a Companhia de Saneamento básico do Estado de São Paulo (Sabesp) com a execução do Sistema Produtor São Lourenço, que consiste num conjunto de instalações para captação de uma vazão média anual de 4,7 m3/s de água no Reservatório Cachoeira do França (na bacia do Alto Juquiá), no município de Juquitiba, logo após a foz do rio São Lourenço.

O Sistema Produtor São Lourenço (SPSL) objetiva aumentar a oferta de água tratada para reforço e regularização do abastecimento público de água na zona oeste da RMSP, mediante interligação ao Sistema Integrado Metropolitano (SIM) de Abastecimento de Água da RMSP. O SPSL compõe-se de um conjunto de instalações lineares e mais instalações localizadas - tomada de água, estações elevatórias, chaminés de equilíbrio, Estação de Tratamento de Água (ETA) e reservatórios - situados no território de 10 municípios da RMSP e mais Ibiúna. (RIMA, 2011, p. 01).

O projeto entrou em execução no auge da crise hídrica que se abateu sobre o Estado de São Paulo no ano de 2014 e que se agravou no ano posterior. Com os estudos de impacto ambiental e os relatórios concluídos desde 2011, as obras puderam ser iniciadas devido à urgência na busca de alternativas para a estabilização da crise.

Os impactos de maior relevância no ambiente natural são referentes à supressão de vegetação, interferências com APP, e fragmentação de habitats por afetação de bordas e abertura de clareiras em fragmentos florestais em estágio médio de regeneração. Terão medidas compensatórias no Programa de Manejo e Reposição de Vegetação, que supre as perdas com vantagem, atendendo às exigências da legislação vigente. De acordo com a Lei 9.985/00, os aspectos não-mitigáveis desses impactos, em função de interferências em remanescentes naturais existentes, implicações sobre a fauna e outros impactos inevitáveis sobre a biodiversidade, serão compensados mediante apoio ao fortalecimento de unidade de conservação, conforme previsto no Programa de Compensação Ambiental.

Em termos globais, o sistema hidráulico do SPSL deve causar a supressão de 21,1 ha de vegetação natural significativa (estágios inicial e médio, ciliar e de várzea), supressão de 57,5 ha de vegetação antropizada (estágio pioneiro, campos, brejos, arborização etc.), afetação de $8,1 \mathrm{~km}$ de bordas e abertura de $0,65 \mathrm{~km}$ de clareiras em fragmentos florestais em estágio médio, travessia subterrânea de 110 córregos e interferência e 39,2 ha de APP. A relocação de população e atividades (a princípio, cerca de 14,9 mil $\mathrm{m}^{2}$ de construções, 86 domicílios e usos mistos, e 5 atividades econômicas), terão tratamento compensatório adequado através dos Programas de Indenização e Reassentamento. (RIMA, 2011, p. 185) 
4.6 Políticas públicas ambientais no município de Juquitiba

\subsubsection{Lei de proteção aos mananciais}

A partir da década de 1970, o município de Juquitiba foi fortemente influenciado pelas políticas ambientais implementadas pelo Estado. Incide sobre o município e mais outros 53\% do território da RMSP, que envolve os reservatórios que integram o sistema metropolitano de água a Lei de Proteção aos Mananciais (Leis Estaduais 898/75, 1.172/76, Decreto Estadual n ${ }^{\text {o }}$ 9.714/1977). Este decreto dispõe sobre diretrizes e normas para a proteção e recuperação das bacias hidrográficas dos mananciais de interesse regional do Estado de São Paulo. As águas dos mananciais protegidos por esta lei são prioritárias para o abastecimento público em detrimento de qualquer outro interesse.

Esta legislação impôs severas restrições relacionadas ao uso e à ocupação do solo. Desde meados da década de 1990, o Estado vem implementando um novo modelo de planejamento e gestão das bacias hidrográficas estaduais, deflagrando a Política Estadual de Recursos Hídricos de São Paulo (Lei no 7633/1991), que culminou na revisão da Lei de Proteção dos Mananciais, em 1997, por meio da instituição da Lei Estadual nº 9.866.

As legislações que incidem sobre as áreas de proteção aos mananciais e sobre os recursos hídricos do estado de São Paulo incorporam a bacia hidrográfica como unidade de intervenção e os comitês de bacias como instâncias deliberativas de planejamento e gestão da unidade hídrica com representação da sociedade civil e representantes do poder político estadual e municipal. Com a Lei de 1997, a responsabilidade de planejamento e gestão das bacias hidrográficas que abrigam mananciais de abastecimento urbano passou a ser do Comitê e subcomitês, que assumiram a responsabilidade de elaborar leis específicas para a unidade de intervenção ou Área de Proteção e Recuperação dos Mananciais de modo a regulamentar a Lei 9.866 (ALVIM; KATO; BRUNA; 2012 p. 110).

O município de Juquitiba tem seu território $100 \%$ protegido por essa legislação. Essa abrangência contribui para severas restrições na política de parcelamento, ocupação e uso do solo, principalmente na preservação do rio Juquiá que integra a unidade de planejamento da Bacia Hidrográfica do Ribeira de Iguape e Litoral Sul CBH - RB, localizada ao sul do Estado de São Paulo, numa extensão aproximada de $260 \mathrm{~km}$, com uma testada de $140 \mathrm{~km}$ para o Oceano Atlântico. 
4.6.2 Unidades de conservação no município de Juquitiba

No município de Juquitiba o ordenamento territorial ocorre em função das legislações ambientais que incidem sobre o mesmo. A figura a seguir indica as Unidades de Conservação estabelecidas.

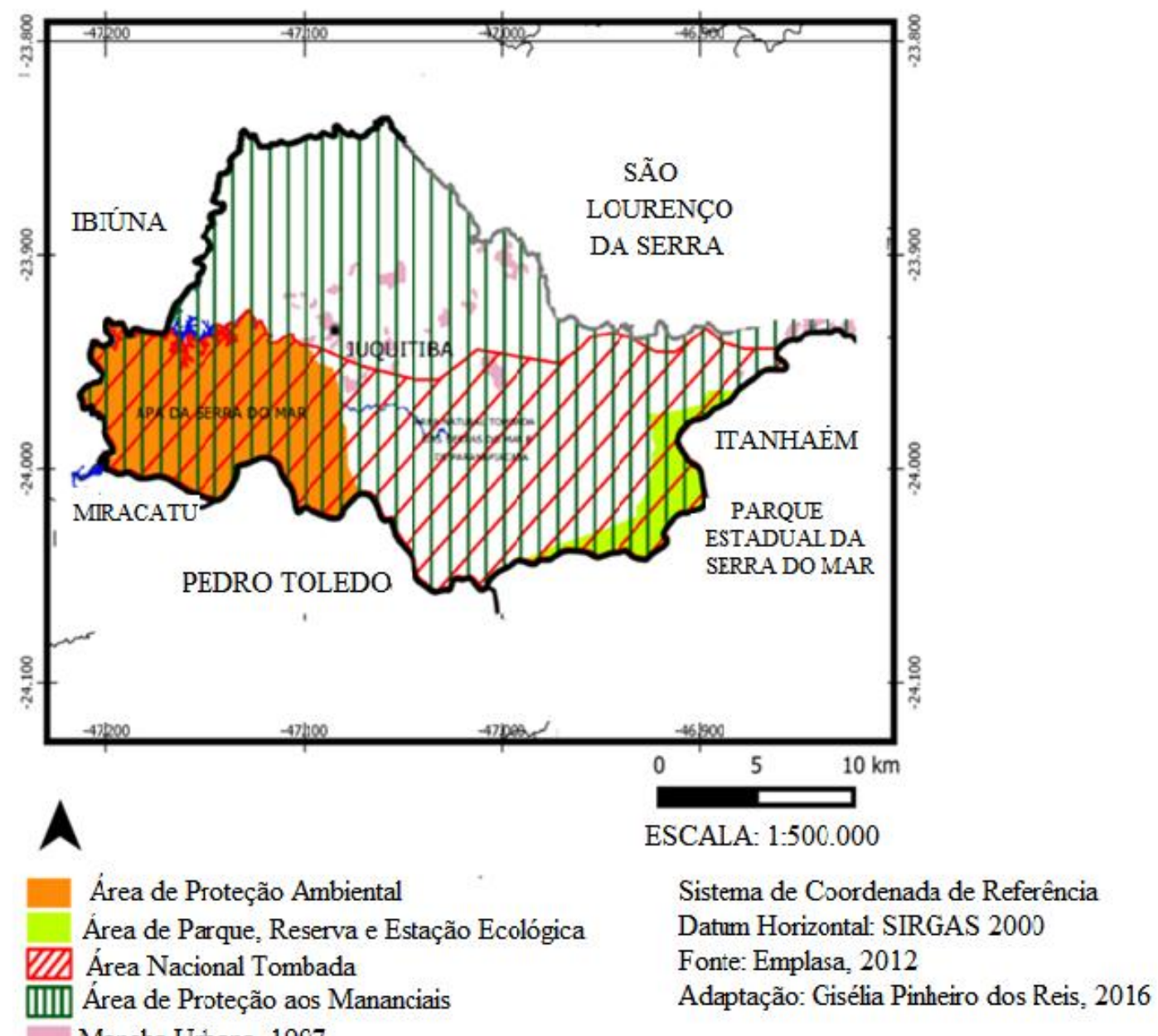

Figura 3: Unidades de Conservação no Município de Juquitiba

\subsubsection{Parque estadual da Serra do Mar}

Na década de 1970, pelos decretos 10.251 de 30 agosto de 1977 e 13.313, de 06/03/79, foi criado o Parque Estadual da Serra do Mar. O PESM abrange 5,35\% do território do município de Juquitiba no Núcleo Curucutu. Este parque constitui uma Unidade de Conservação de Proteção Integral e contribuiu para restringir atividades mais impactantes como a especulação imobiliária, agronegócio ou grandes indústrias de extração, estimulando a implementação de atividades menos comprometedoras do equilíbrio natural do município 
como o uso indireto da natureza pelas populações tradicionais, pelo turismo ou pela pesquisa científica.

\section{Parque Estadual da Serra do Mar - Núcleo Curucutu - limites com o município de Juquitiba}

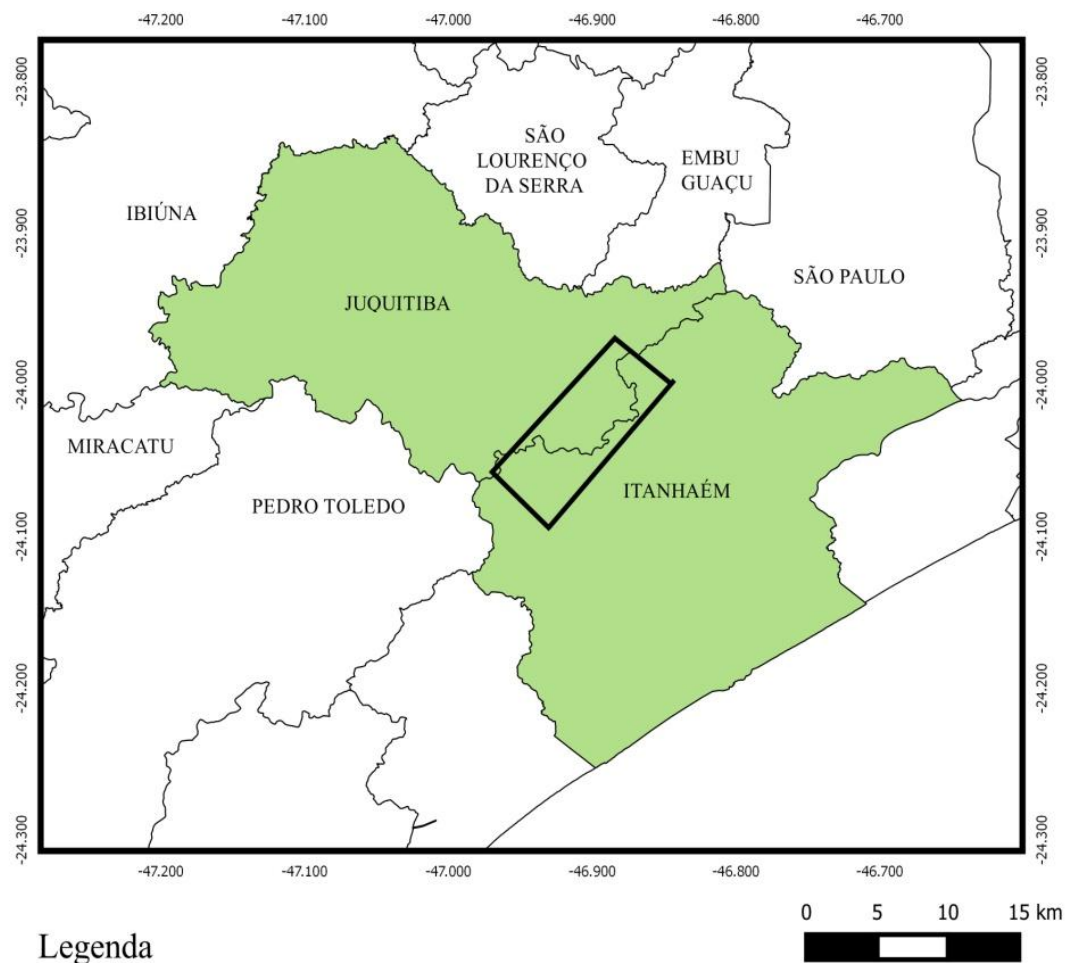

Legenda

$\square$ Núcleo Curucutu - limites com o município de Juquitiba

ESCALA: $1: 500.000$

Sistema de Coordenada de Referência

Datum Horizontal: SIRGAS 2000

Fonte: Mapa Digital do Estado de São Paulo

Elaboração: Gisélia Pinheiro dos Reis, 2016

Figura 4: Parque Estadual da Serra do Mar - Núcleo Curucutu - limites com o município de Juquitiba - SP 
O Núcleo Curucutu do Parque Estadual da Serra do Mar tem seu histórico alicerçado na preservação do Manancial que atende a metrópole paulista quando, em 1958 a Fazenda Curucutu, produtora de Carvão, foi adquirida pelo Estado, que pelo decreto $\mathrm{N}^{\mathrm{o}} 36.544 / 60$ tornara seus 12.029,00 ha, em Reserva Florestal. Esta região se caracteriza como borda do planalto paulista e passa pela bacia dos rios Capivari e Monos da APA do mesmo nome, pela Reserva de Manancial do rio Embú-Guaçú, no extremo sul da cidade de São Paulo, chegando à divisa do Planalto de Itanhaém com Juquitiba.

Os remanescentes de Mata Atlântica presentes no Parque estão sob constante ameaça ao seu equilíbrio ambiental, pois historicamente trata-se de uma das regiões mais habitadas e exploradas do país. A pressão urbana, a implantação de infraestrutura básica e de desenvolvimento regional, como estradas, portos e linhas de transmissão, o turismo desordenado, o extrativismo e a caça sistemática são exemplos das pressões que o Parque sofre desde sua criação e que causam degradação e perda de biodiversidade. Assim, qualquer iniciativa de planejamento e gestão deve incluir diretrizes e ações que abordem esses conflitos socioeconômicos e políticos e busquem alternativas que tentem solucioná-los.

O principal instrumento de planejamento e gestão é o Plano de Manejo, cujos esforços relativos à sua elaboração intensificaram-se a partir de 1997, com a elaboração de Planos de Gestão Ambiental. Conceitualmente, um Plano de Manejo apresenta a sistematização do conhecimento sobre o meio físico e biológico de uma determinada unidade de conservação, assim como as características sociais, ambientais e econômicas que a envolvem. O conhecimento gerado subsidia discussões com as comunidades locais e com toda a sociedade, dentro das concepções de planejamento e gestão participativos. Os principais resultados do processo de planejamento participativo são o zoneamento da área protegida e as propostas de diretrizes, estratégias, ações e atividades, organizadas em programas de manejo.

O Plano de Manejo do PESM contou com o levantamento e análise do ecossistema natural (fauna, flora, recursos hídricos e sistemas ecológicos), do patrimônio cultural, das pressões e ameaças causadas pela ocupação humana, do uso público (incluindo visitação e educação ambiental), e da gestão do Parque, tanto em termos organizacionais quanto financeiros.

No Plano de Manejo estão especificados dois tipos de zoneamento: Zona de Ocupação Temporária, que apresenta as seguintes especificidades: todas as áreas de uso antrópico, com exceção daquelas ocupadas por infraestrutura de base e Zona Histórico-Cultural, que tem por objetivo respeitar direitos de posse e propriedade, e principalmente os direitos históricos dos 
ocupantes que nasceram, residem e dependem do lugar onde vivem para sua sobrevivência. Nessas áreas foram incluídas as ocupações das populações predominantemente tradicionais caiçaras e quilombolas, que de acordo com o documento, estão em processo de reclassificação na sua categoria de manejo. Enquanto isso não ocorre, o documento tem garantido sua diferenciação para valorizar e assegurar condições da continuidade do modo de vida destas populações.

\subsubsection{APA da Serra do Mar}

A Área de Proteção Ambiental da Serra do Mar foi criada pelo DECRETO ESTADUAL N ${ }^{\circ}$ 22.717, DE 21 DE SETEMBRO DE 1984, entre as regiões situadas nas encostas da Serra do Paranapiacaba e adjacências, em terras dos Municípios de Apiaí, Capão Bonito, Eldorado Paulista, Guapiara, Ibiúna, Iporanga, Juquiá, Juquitiba, Miracatu, Pedro de Toledo, Pilar do Sul, Sete Barras e Tapiraí. A implantação desta Área de Proteção Ambiental tem como principal missão a preservação dos Mananciais que atendem tanto à metrópole paulista como a Baixada Santista, além de garantir a integridade física da área e ser o corredor biológico da Mata atlântica. Tem por objetivo coibir o exercício de atividades causadoras de degradação da qualidade ambiental citadas no artigo $4^{\circ}$

"I" - a implantação de atividades potencialmente poluidoras capazes de afetar mananciais de águas, o solo e o ar; II - a realização de obras de terraplenagem e a abertura de canais que importem em sensível alteração das condições ecológicas locais; III - o exercício de atividades capazes de provocar acelerada erosão das terras ou acentuado assoreamento nas coleções hídricas; IV — o exercício de atividades que ameaçam extinguir as espécies raras, endêmicas e ameaçadas de extinção da biota local".

A APA constitui uma Unidade de Conservação de uso sustentável caracterizada como

[...] áreas geralmente extensas, com um certo grau de ocupação humana, dotadas de atributos abióticos, bióticos, estéticos ou culturais especialmente importantes para a qualidade de vida e o bem-estar das populações humanas, e tem como objetivos básicos proteger a diversidade biológica, disciplinar o processo de ocupação e assegurar a sustentabilidade do uso dos recursos naturais. (SEMA, 1981) 
A política ambiental que regulamenta a APA tem por esforço compatibilizar a conservação da natureza com o uso sustentável dos recursos, conciliando a presença humana nas áreas protegidas.

\subsubsection{Parque estadual do Jurupará}

Em 22 de setembro de 1992, por meio do Decreto $\mathrm{n}^{\circ}$ 35.703, o Governador do Estado de São Paulo transformou em Parque Estadual do Jurupará a área correspondente à Reserva Estadual Florestal do $2^{\circ}$ Perímetro de São Roque, com 23.900,47 ha. Esse processo teve início décadas antes, com o levantamento de terras devolutas presentes no território do Estado e tem por finalidade proteger e conservar todo o complexo ecológico ali existente.

A criação desta Unidade de Conservação deve-se à necessidade de proteção e conservação da riqueza de seus recursos hídricos e à necessidade de garantir a conservação do fragmento de Mata Atlântica que existe na área do Parque, além de contribuir para o crescimento do "mosaico" regional de Unidades de Conservação deste bioma que pertence a um dos maiores corredores de Mata Atlântica do país, integrado desde 1991 à Reserva da Biosfera Mata Atlântica.

Esta área é importante abrigo de mananciais e está inserida na bacia hidrográfica do Ribeira de Iguape, sub-bacia do Alto Rio Juquiá. Os recursos hídricos do PEJU podem ser, futuramente, a garantia de abastecimento de água de qualidade para a capital do Estado e cidades adjacentes, já que a demanda por este recurso natural continua crescente. 


\section{PARQUE ESTADUAL DO JURUPARÁ}

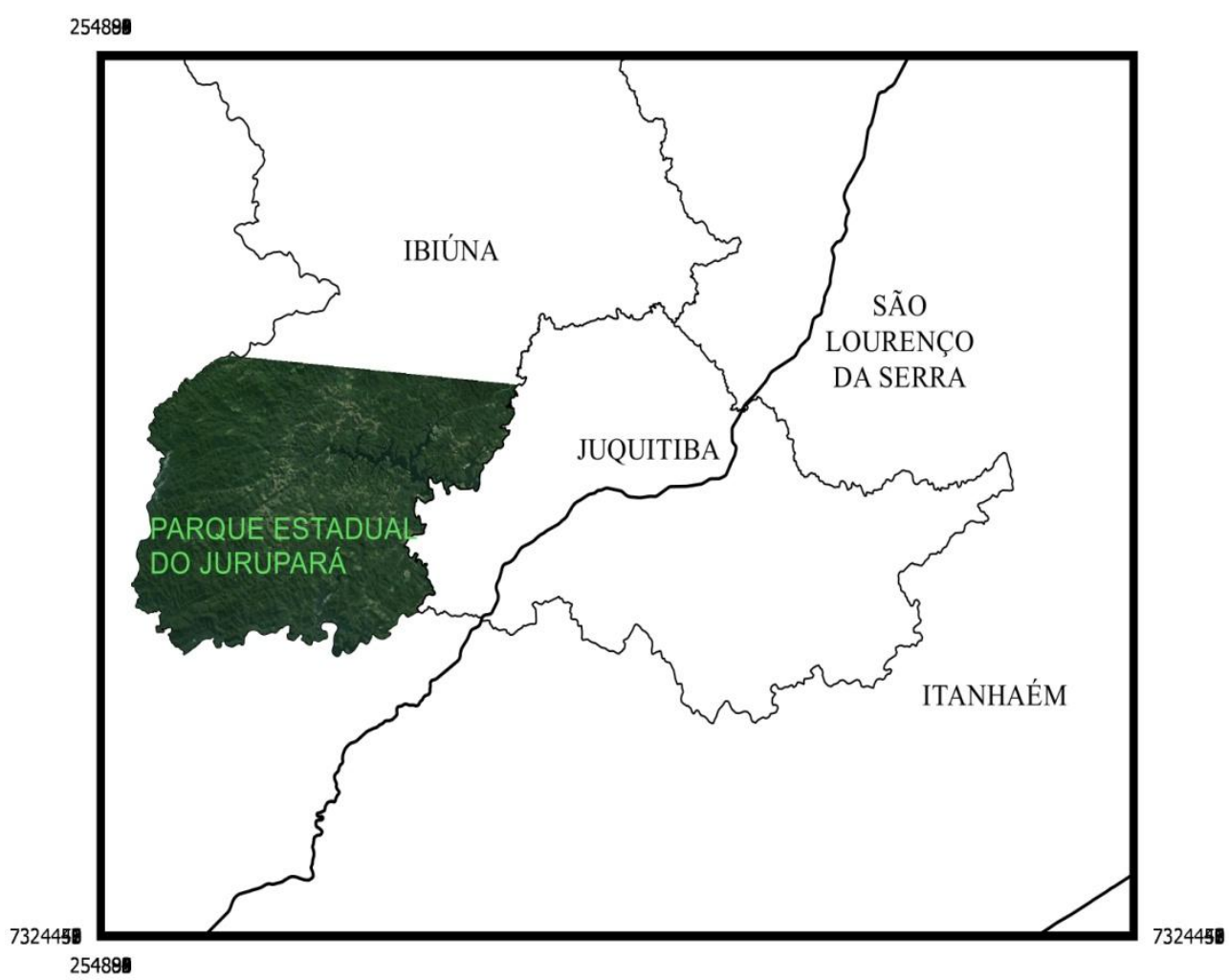

Projeção Universal Transversa de Mercator Datum Horizontal: WGS 84 - UTM 23S Fonte: Mapa Digital do Estado de São Paulo Elaboração: Gisélia Pinheiro dos Reis, 2016

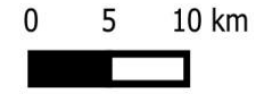

ESCALA: 1:500.000

Figura 5: Parque Estadual do Jurupará - limites com o município de Juquitiba - SP 
O Plano de Manejo inclui nos limites com Juquitiba uma área de pressão antrópica. Entende-se por pressão antrópica qualquer atividade humana que de alguma forma interfira nos mecanismos naturais de funcionamento de uma unidade ecológica ou sistema (SUHOGUSOFF e PILIACKAS, 2007).

O Índice de Pressão Antrópica (IPA) engloba os indicadores de atividade agrícola (área cultivada), pecuária (lotação relativa), extrativismo (lenha) e pressão populacional (densidade rural) e se baseia nos dados censitários, relacionando-os com o tamanho da área (região ou município) onde é realizado um cruzamento dos valores de estoque (densidade da área cultivada, rebanho bovino, população rural e produção vegetal) e fluxo (taxas médias geométricas de crescimento anual).

De acordo com Ricklefs (2003) o nível de pressão antrópica sobre determinado sistema depende do tipo de ação humana aplicada, bem como da capacidade de suporte do ambiente em responder de forma positiva ou negativa, ou ainda de forma rápida ou lenta aos diferentes tipos de intervenção humana em seu funcionamento. Pode ser medida através de informações socioeconômicas disponibilizadas por órgãos públicos competentes, pois segundo Monteiro e Sawyer (2001), os dados censitários fornecidos pelo IBGE ou por instituições municipais são fontes seguras de informações sociais e econômicas que contribuem para a análise da pressão antrópica sobre o ambiente.

No Sistema Nacional de Unidades de Conservação, em seu artigo 27, parágrafo primeiro diz que

Plano de Manejo deve abranger a área da unidade de conservação, sua zona de amortecimento e os corredores ecológicos, incluindo medidas com o fim de promover sua integração à vida econômica e social das comunidades vizinhas". E o artigo $2^{\circ}$ esclarece que: "XVIII - zona de amortecimento: o entorno de uma unidade de conservação, onde as atividades humanas estão sujeitas a normas e restrições específicas, com o propósito de minimizar os impactos negativos sobre a unidade.

Essas zonas de amortecimento se inserem no Sistema Nacional de Unidades de Conservação com o objetivo de contribuir para a manutenção da estabilidade e equilíbrio do ecossistema garantindo a integridade da área protegida. A preocupação com o entorno da Unidade de conservação aparece registrada em outras legislações como: na resolução CONAMA no 13/901 e depois na Lei do SNUC (Lei Federal no 9985/2000), que determina que todas as unidades de conservação, com exceção das APAs e RPPNs, tenham a sua "zona de amortecimento" definida. 
A zona de amortecimento configura-se assim como um espaço territorial que, em virtude de sua proximidade e contiguidade em relação às áreas protegidas, é afetado pelo regime especial de conservação da natureza que rege esta região, passando a possuir também, um regime diferenciado de fruição, que estabelece controle e restrições a determinadas atividades com o objetivo de filtrar os impactos negativos de atividades externas a ela, tais como: ruídos, poluição, espécies invasoras e avanço da ocupação humana, no caso de Unidades localizadas em áreas fortemente ocupadas (MILLER, 1997). No Plano de Manejo do PEJU ainda como proposta no ano de 2009, aparece especificado territorialmente as áreas de amortecimento ou "zona tampão".

4.6.6 Plano diretor do município e o planejamento ambiental

O respaldo legal à proteção ao meio ambiente é dado pelo Plano Diretor do município, que institui a política de saneamento ambiental integrado com o objetivo de manter o meio ambiente equilibrado e de alcançar níveis crescentes de salubridade, por meio da gestão ambiental, do abastecimento de água potável, da coleta e tratamento do esgotamento sanitário, do manejo dos resíduos sólidos e da drenagem e reuso das águas pluviais, promovendo a sustentabilidade ambiental do uso e da ocupação do solo (artigo $15^{\circ}$ ).

Dispõe sobre o ordenamento territorial ao ressaltar que o planejamento do desenvolvimento da cidade, da distribuição espacial da população e das atividades econômicas do município, deve ocorrer de modo a evitar e corrigir as distorções do crescimento urbano e seus efeitos negativos sobre o meio ambiente (artigo $44^{\circ}$ ).

A conservação ambiental composta pelo Parque Ecológico Municipal, Nascentes, Rios e Córregos, Represa Cachoeira do França, Mata natural de primeira categoria, Espécies de flora em extinção e por recursos naturais de interesse ambiental e por áreas de alta restrição à ocupação e aquelas definidas em leis específicas está prevista no artigo $72^{\circ}$ e tem por objetivo promover a manutenção da qualidade ambiental e conservar os recursos naturais.

A proteção ambiental do município ainda é contemplada no projeto de lei № 08/2009 do executivo, que institui e disciplina o plano municipal de proteção e controle do meio ambiente do município de Juquitiba. Em seu artigo $8^{\circ}$ estabelece que "O zoneamento ambiental consiste na definição de áreas do território do Município, a fim de regulamentar as atividades, bem como definir ações para a proteção e melhoria da qualidade do ambiente, considerando as características ou atributos das áreas”. E nos artigos seguintes define as zonas ambientais do município: 
- Art. 10 - As Zonas de Unidades de Conservação são áreas sob regulamento das diversas categorias de manejo, as quais serão elaboradas individualmente de acordo com suas características peculiares.

- Art. 11 - As Zonas de Proteção Ambiental são áreas protegidas por instrumentos legais diversos;

- Art. 12 - As Zonas de Proteção Paisagística são áreas de proteção de paisagem com características excepcionais de qualidade, fragilidade e beleza cênica;

- Art. 13 - As Zonas de Recuperação Ambiental são áreas em estágios significativos de degradação, onde são exercidas a proteção e desenvolvidas ações visando a recuperação induzida ou natural do ambiente, com o objetivo de integrá-lo às zonas de proteção ou quaisquer outras;

- Art. 14 - As Zonas de Controle Especial são as demais áreas do Município submetidas a normas próprias de controle e monitoramento ambiental, em função de suas características. 


\section{5 - MUNICÍPIO DE JUQUITIBA EM MAPAS TEMÁTICOS}

\subsection{MATERIAIS E MÉTODOS}

\subsubsection{Cartografia Temática na elaboração de cenários ambientais}

Neste capítulo são apresentados os métodos usados na produção cartográfica e a análise dos cenários ambientais representados a partir de uma perspectiva do Geossistema. As contribuições do geossistema para o trabalho em questão ocorrem no âmbito do fornecimento de um conhecimento integrado das intrínsecas relações entre os diferentes elementos bióticos e abióticos, de forma que qualquer alteração decorrente da ação humana sobre o meio natural afetará todo o sistema.

A dinâmica socioeconômica atual tem promovido intensas transformações no espaço geográfico, o que tem exigido um conhecimento aprofundado das potencialidades e fragilidades do meio natural que tem como alternativa a elaboração de cenários ambientais utilizando a cartografia temática, contribuindo para a proposição de diagnósticos ambientais, com a utilização de softwares livres e de baixo custo sem prejuízo da informação geográfica, e que atenda as necessidades de municípios pequenos que buscam a prática do planejamento ambiental com ênfase no uso e exploração sustentável dos recursos naturais.

A cartografia temática direcionada para a representação de variáveis ambientais envolve a coleta, tratamento e apresentação de dados e informações do ambiente, incluídos os aspectos socioeconômicos que possam influenciar diretamente os processos bióticos e abióticos, tendo em vista a sua caracterização multifacetada em diversas dimensões e sua complexidade, desde a origem dos fenômenos, até os seus efeitos.

As representações construídas contemplam o diagnóstico ambiental enquanto método que reúne diferentes dados sobre a região de interesse como os levantamentos temáticos (geologia, geomorfologia, solos, cobertura vegetal) para posteriormente analisá-los de forma sistêmica. O processo analítico da situação ambiental do município de Juquitiba pressupõe a identificação dos elementos que compõe o sistema natural da região, considerando os processos naturais e sociais que atuaram em sua formação. A partir dessa síntese, é possível inferir sobre a importância e prioridades do planejamento ambiental para eventual intervenção ou um prognóstico baseado no quadro apresentado. 
O mapa se configura como um importante instrumento de análise integrada contribuindo para o estudo da dinâmica da paisagem dentro do espaço geográfico, dos processos específicos da relação sociedade-natureza definindo áreas verdes e de degradação até a identificação de outros ambientes, para que se tenha um mapa em que se possa fazer uma análise prática e tomar decisões de gerenciamento ambiental da situação de tais áreas.

\subsubsection{Fonte de dados}

A elaboração de mapas temáticos é precedida pela aquisição de fontes de dados que podem ser de ordem primária ou secundária. As fontes de dados primárias empregadas na construção deste trabalho envolveu a coleta de dados de coordenadas geográficas com utilização de imagens de satélite em conjunto com a base cartográfica para delimitação da área de interesse, levantamento de informações da configuração espacial (como as formas de ocupação das terras); a interpretação de imagens orbitais com a mesma finalidade e ainda a aplicação de questionários e entrevistas, visando obter dados sobre as características atuais do espaço analisado. As fontes secundárias referem-se aos mapas já existentes, como os levantamentos cartográficos do Instituto Brasileiro de Geografia e Estatística (IBGE), de órgãos estaduais e municipais e de empresas privadas, os dados tabulares e textuais elaborados por essas entidades, como por exemplo, os censos demográficos e agropecuários, os anuários estatísticos, os relatórios técnicos, os artigos, as monografias, as dissertações e as teses. Entre os mapas temáticos elaborados a partir dessas fontes, destacam-se os de uso e ocupação das terras, das formas do relevo (declividade e hipsométrico). Os mapas de uso e ocupação das terras representam as atividades econômicas já instaladas sobre o território em questão, como a agricultura, a pecuária, as áreas urbanas, a malha viária e as áreas verdes remanescentes.

Mapas sobre o relevo, como os clinométricos (Figura 06) e os hipsométrico (figura 07) apresentam características fisiográficas sobre as paisagens que permitem, por exemplo, observar as restrições à instalação de determinadas formas de ocupação, como edificações de grande porte, abertura de estradas, construção de barragens etc. Eles se conjugam aos mapas geotécnicos e geológicos, dependendo do tipo de empreendimento.

\subsubsection{O uso do SIG}


O uso do geoprocessamento nesta etapa da pesquisa significou um ganho considerável, especialmente a partir do cruzamento dos mapas temáticos utilizando-se sistemas de informações geográficas (SIG). As vantagens desses sistemas é o fato de permitirem a integração de dados de diversas fontes numa mesma base, inclusive comunicando diversas escalas e distintas projeções. No entanto, exige-se do pesquisador postura de correlacionar, analisar e avaliar os resultados.

Os mapas que integram este trabalho foram desenvolvidos em SIG Quantum GIS (QGIS). Este é um software livre e gratuito, multiplataforma, com uma interface gráfica simples que permite a produção de arquivos para um SIG através de conexões com banco de dados PostGIS. O projeto que deu origem ao Quantum GIS teve início no ano de 2002 como objetivo criar um visualizador gratuito para a base de dados PostGIS que funcionasse em sistemas operacionais livres e recebe constantes contribuições de voluntários e de profissionais da área de geoprocessamento que buscam aprimorar o software identificando e divulgando suas falhas, produzindo tutoriais, traduzindo manuais, gerando novas ferramentas e aprimorando as já existentes.

O QGIS permite consultas espaciais, exploração interativa de dados, identificação e seleção de geometrias, pesquisa, visualização e seleção de atributos e criação de simbologia vetorial e raster, incluindo sobreposição, recorte, buffer, amostragem, interpolação TIN (Triangular Irregular Network), interpolação IDW (Inverse Distances Weight), análise de parâmetros morfológicos e gestão das geometrias dos dados associados.

O plugin GRASS - instalado automaticamente com o QGIS - dá acesso a comandos que permite análises SIG complexas, tanto raster como vetorial, incluindo álgebra de mapas, modelação hidrológica, interpolação de superfícies, análise de redes, análise de imagem, operações de base de dados e outras. Os mapas de drenagens (figuras 16 e 17) foram elaborados através de operações com o GRASS.

\subsubsection{Sensoriamento Remoto}

As técnicas de Sensoriamento Remoto empregadas neste trabalho seguiram os princípios de ações de levantamento de dados, informações e imagens da superfície terrestre, com o intuito de representá-las e melhor entender os seus aspectos. Para o estudo das características morfoestruturais do município de Juquitiba foram obtidos dados gerados a 
partir de imagens SRTM que apresenta um modelo da topografia do terreno de alta resolução. Este sensor se destaca por ser de uso público. Entre as possibilidades de estudos a partir de imagens SRTM destaca-se a análise da rede de drenagem extraída automaticamente deste produto, as informações altimétricas e clinográficas.

\subsection{5 - Categorias de análise da Cartografia}

a) Delimitação da área de estudo

Esta é a primeira etapa para o processo de mapeamento temático que representem os cenários ambientais. Envolve uma reflexão sobre a área de estudo bem como inventário dos elementos físicos da paisagem, dos problemas socioambientais e da proporção das unidades territoriais envolvidas. A delimitação da área de estudo é determinada pela escolha da escala cartográfica e geográfica.

b) Escalas de trabalho

Os mapas temáticos que integram este trabalho foram elaborados em diferentes escalas em função da necessidade de adequar os produtos provenientes do Sensoriamento Remoto como as imagens SRTM à base cartográfica utilizada. As escalas adotadas, consoante com o objetivo geral, permitiram avaliar a aplicação da cartografia temática na elaboração dos cenários ambientais e se mostraram adequados para a realização da análise dos aspectos naturais, principalmente através da prática de inventariá-los e descrevê-los.

c) Tratamento Gráfico e Visual da Informação

Os mapas são considerados representações gráficas, forma particular de comunicação visual com propriedade monossêmica. De acordo com Joly (1990, p. 13), a linguagem visual apresenta a propriedade de ser universal ao utilizar símbolos compreensíveis por todos, mesmo na condição de iniciante em saberes cartográficos. O trabalho cartográfico com mapas tem por objetivo retratar visualmente objetos ou fenômenos existentes na realidade que são descritos por meio das variáveis de proporção, ordem ou de diversidade com a utilização de signos apropriados que deem conta de oferecer ao usuário uma compreensão da realidade por meio da abstração. Uma vez aplicadas aos mapas, essas variáveis são descritas na legenda, expressando o significado de cada cor, forma ou textura, e ainda na toponímia, os nomes dos lugares lançados diretamente sobre o mapa. A escolha da variável deve garantir que a transcrição visual seja fiel à natureza original das relações entre os dados, sem margem para a transmissão ambígua de informações. 
d) Cartografia analítica

A elaboração dos cenários ambientais abordados neste trabalho através da cartografia temática seguiu os princípios metodológicos de uma das etapas da cartografia: a cartografia analítica. As Cartas de Análise tem por objetivo cartografar elementos ou processos simples, atentando para seus elementos constitutivos, lugares, caminhos ou áreas caracterizadas por seus atributos ou variáveis, como as coberturas superficiais, as formações geológicas, as distribuições fitológicas, os espaços agrícolas, tipos de construções urbanas, densidades populacionais, rejeitos e poluições do ar, da água etc.

A Cartografia Analítica é eminentemente quantitativa, mostrando a distribuição de um ou mais elementos de um fenômeno, utilizando para isso informações oriundas de dados primários. De uma forma geral ela classifica, ordena e hierarquiza os fenômenos a representar, atentando-se para todos os elementos constitutivos através de justaposições ou sobreposições. Através da qual, mediado pelo levantamento físico e socioeconômico, o planejador analisa graficamente, de forma fragmentada, todos os elementos necessários para a construção de cenários representativos de sua realidade, tais como: drenagem, geologia, geomorfologia, pedologia, uso e ocupação do solo, entre outros.

A representação gráfica e visual por meio da cartografia analítica possibilita a leitura espacial, interpretação e conhecimento das potencialidades e fragilidades do meio físico e têm como desafio prioritariamente representar de modo real as características e informações relevantes das paisagens inventariadas, permitindo propostas para o planejamento ambiental (ZACHARIAS, 2008).

\subsection{Resultados e discussões}

5.2.1 Aspectos gerais do estudo da declividade, relevo e tipos de solo

A declividade influencia diretamente o processo de escoamento superficial que é resultado da água precipitada que não foi interceptada pela cobertura vegetal ou retida sobre a superfície do terreno e não infiltrou e que, consequentemente, acaba escoando nos caminhos de maior declividade. A depender da qualidade da cobertura vegetal, a declividade é responsável pelos processos erosivos que atacam o solo (TUCCI, 1998). É definida como

a inclinação da superfície do terreno em relação à horizontal, ou seja, a relação entre a diferença de altura entre dois pontos e a distância horizontal entre esses pontos. É dada pelo ângulo de inclinação (zenital) da superfície 
do terreno em relação à horizontal. Os valores de declividade podem variar de $0^{\circ}$ a $90^{\circ}$, e podem também ser expressos em porcentagem (INPE).

A declividade é uma variável geográfica que está presente na legislação brasileira como fator limitante ao uso agrícola. De acordo com Código Florestal Brasileiro: "áreas em topos de morros ou com inclinação acima dos $45^{\circ}$ devem ser preservadas". Ela pode ser estimada através de curvas de nível ou pontos de elevação, ou no campo com clinômetros. $\mathrm{O}$ estudo das interações da declividade, solos e uso da terra pode ser feito com o uso do geoprocessamento. Esses instrumentos possibilitam o armazenamento e gerenciamento desses dados, com rapidez e precisão, além de permitir a identificação de áreas propícias à degradação ambiental e à avaliação das estratégias de manejo (CÂMARA \& DAVIS, 2002). Com a disponibilização dos dados SRTM (Shuttle Radar Topography Mission), é possível mapear a declividade em escala de pequena a média para quase toda a superfície terrestre, com imagens do Topodata disponibilizadas pelo INPE ou pela EMBRAPA.

O mapa de declividade é relevante porque apresenta grande potencial para os estudos geológicos, hidrológicos, ecológicos e geomorfológicos. A geração de mapas temáticos de classes de declividade tem se destacado como uma técnica importante na detecção de áreas críticas para deslizamento de encostas, traçados de perfis ecodinâmicos da paisagem e análises de terreno para construção em áreas urbanas, bem como, no planejamento do desenvolvimento sustentável da agricultura, programas de manejo de bacias hidrográficas, preservação dos recursos florestais, o zoneamento ecológico e econômico, os estudos de conservação dos solos.

De acordo com Lima (2008) a influência do solo sobre a infiltração está relacionada às características como textura e estrutura. A textura refere-se à proporção dos elementos contidos no solo sendo divididos em areia, silte e argila, enquanto a estrutura é influenciada pelo arranjo destes componentes, ou seja, a estrutura pode ser afetada pela textura, matéria orgânica, atividade biológica, etc. A estruturação define o tamanho dos poros, em geral solos mais porosos contribuem para a melhoria de outras características como: aeração, infiltração, percolação, capacidade de armazenamento de água, melhor desenvolvimento do sistema radicular, etc.

A região do município de Juquitiba apresenta solos da ordem dos Cambissolos, Cambissolos Háplicos Distróficos e Latossosolos Vermelho-Amarelo. Os Cambissolos abrangem solos minerais com características bastante variáveis, mas que sempre apresentam textura média ou mais fina e ausência de grande desenvolvimento pedogenético. São solos 
com pequena profundidade, elevado teor de minerais primários (minerais herdados da rocha), presença significativa de fragmentos de rocha na massa do solo e outros indícios do intemperismo incipiente do solo.

Em alguns casos, a presença de maiores quantidades de minerais primários nos Cambissolos contribui para uma maior reserva nutricional para as plantas, especialmente importante em áreas de florestas densas perenifólias. Os Cambissolos apresentam cor mais viva, maiores teores de argila e estruturação mais desenvolvida nos horizontes subsuperficiais em relação àqueles materiais puramente herdados da rocha, o que os torna em muitos casos aptos à utilização agrícola, uma vez mitigado alguns fatores restritivos, tais como pedregosidade, pequena profundidade e declividade excessiva. Suas ocorrências mais expressivas estão na província geomorfológica do Planalto Atlântico, em condições de topografia mais íngreme ou relevo mais dissecado. Nestas condições, estes solos têm perfis menos profundos e pedregosidade ou cascalhos na superfície ou na massa do solo.

Os solos do tipo Cambissolos Háplicos Distróficos possuem argila de baixa atividade e de baixa fertilidade e estão presentes em locais com declives acentuados, costumam estar posicionados diretamente sobre a rocha formadora. São pouco profundos e de baixa fertilidade. O manejo adequado ocorre com a calagem, adubação ou em curvas de nível. Os Latossosolos Vermelho-Amarelo correspondem aos solos cujos materiais são os mais decompostos que se formam sob forte influência da umidade e do calor, sua vegetação original de floresta (Mata Atlântica) foi substituída por intensa atividade agrícola.

O material de origem desses solos são: granito, gnaisse e xistos. Em função do intenso intemperismo a que são submetidos, esses solos ficam empobrecidos em nutrientes necessários à vegetação. É um solo típico de floresta que se mantém por uma quantidade mínima de nutrientes periodicamente reciclados pela vegetação. A maior limitação à utilização desses solos deve-se à topografia montanhosa que limita o uso de máquinas e se tornam susceptíveis à erosão.

5.2.2 Aspectos da Cartografia Temática aplicada à análise dos cenários ambientais

\subsubsection{Declividade, relevo e solo}

Os mapas ( figuras 06 e 07) foram elaborados no software QGIS 2.6.1, com uso dos plugins Slope e Reclassify, utilizando o mosaico de imagens SRTM (Shuttle Radar 
Topography Mission) TOPODATA com resolução espacial de 30 metros como dado de base, precedido pela construção de um MDE. A classificação da declividade das formas de relevo adotada como referência foi a do Instituto Brasileiro de Geografia e Estatística - IBGE e EMBRAPA (Plano 0 a 3\%, Suave ondulado 3 a 8\%, Ondulado 8 a 20\%, Forte ondulado 20 a $45 \%$, Montanhoso 45 a $75 \%$ e Escarpado > 75\%).

A variável visual que comunica a informação gráfica representada nos mapas ocorre por meio das cores. Na figura 06, o verde sinaliza para as áreas mais planas do relevo e os tons avermelhados para as áreas de maior declividade. Na figura 07 os tons esverdeados apontam as regiões de menor altitude do município e os tons que segue a gradação de cores do amarelo para o alaranjado indicam as elevadas altitudes do município. 


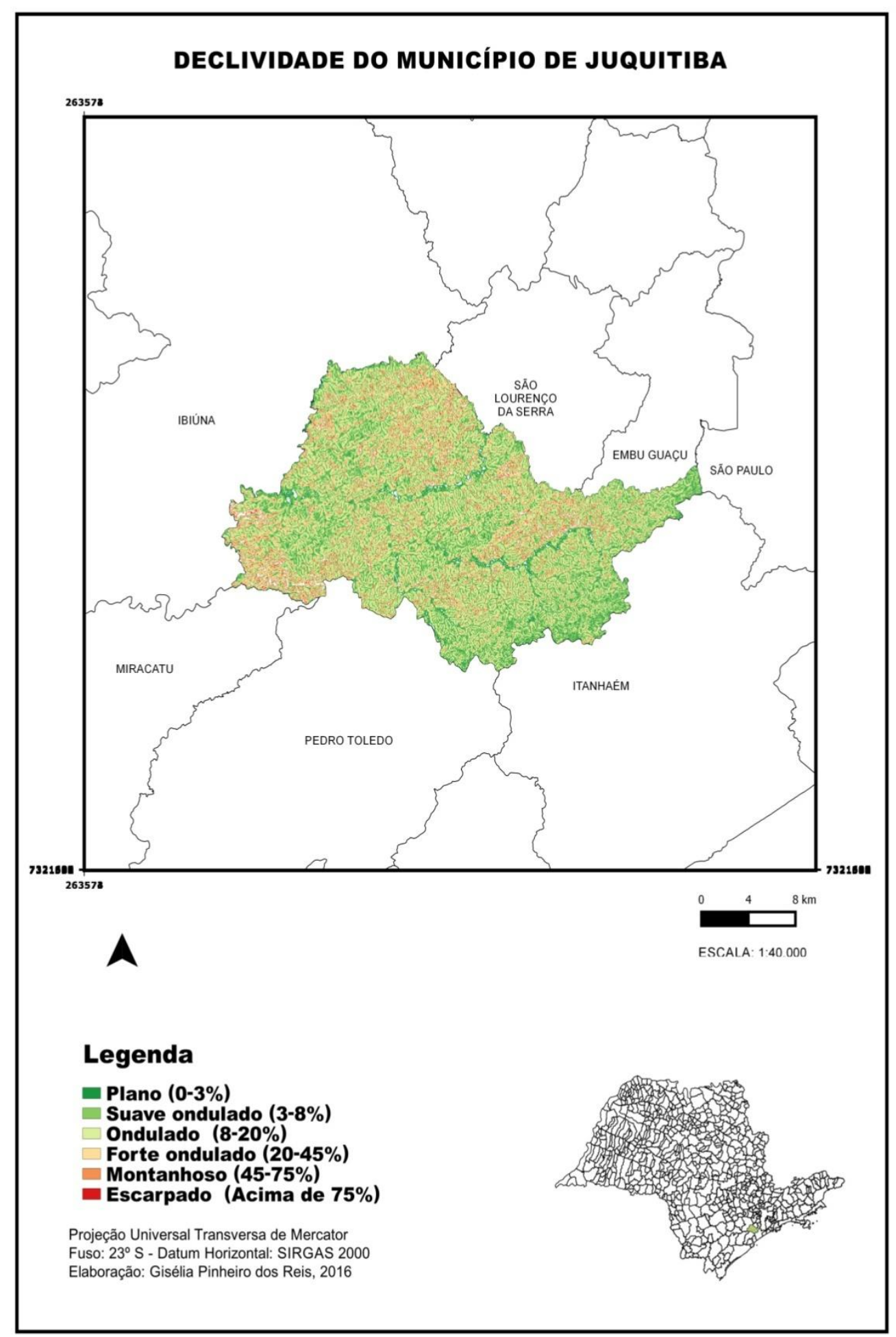

Figura 6: Declividade do município de Juquitiba - SP 


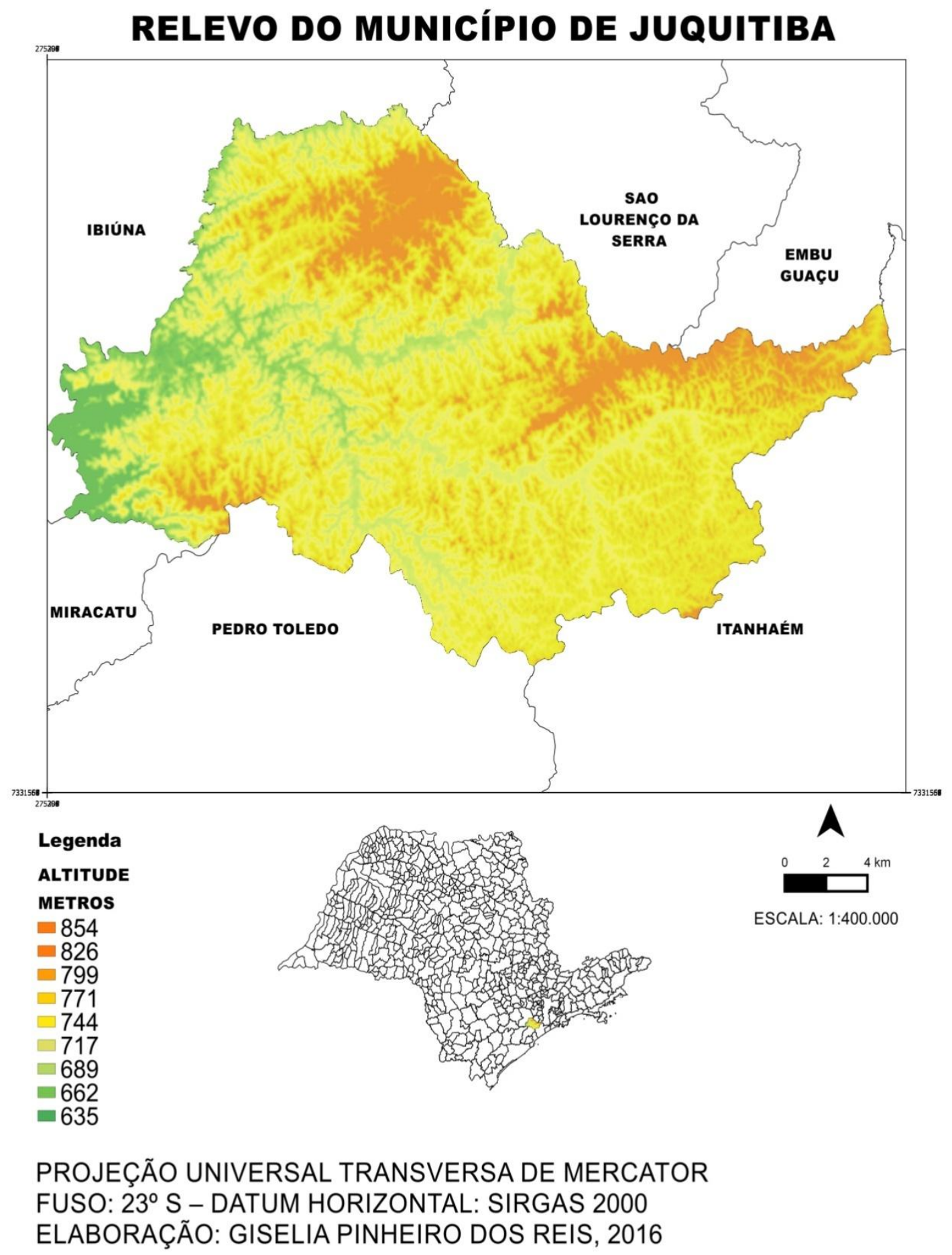

Figura 7: Relevo do município de Juquitiba - SP 
MAPA DE SOLO DO MUNICÍPIO DE JUQUITIBA

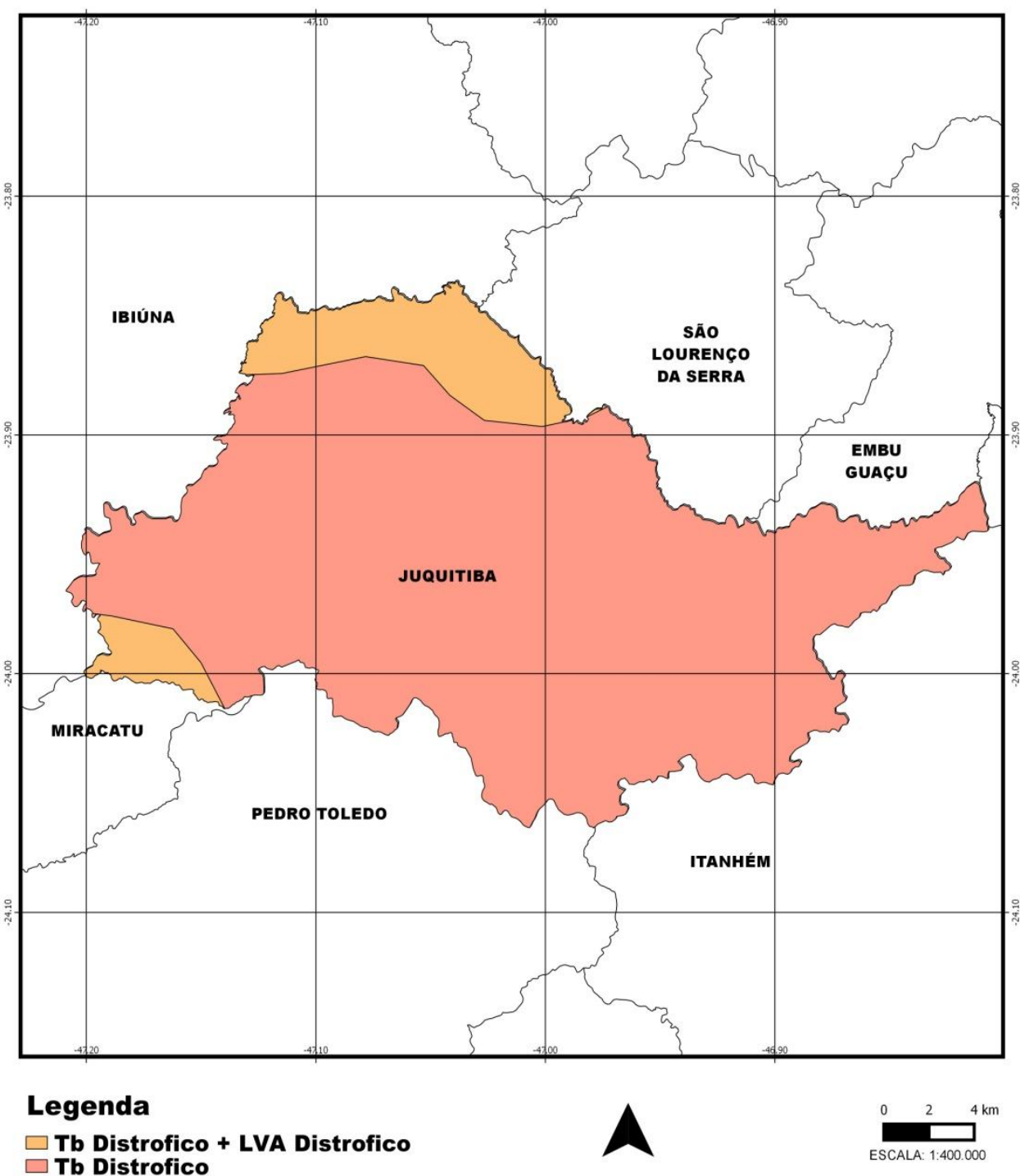

SISTEMA DE COORDENADA GEOGRÁFICA

FUSO: 23 $S$ - DATUM HORIZONTAL: SIRGAS 2000

FONTE: INPE - EMBRAPA, 2016

ELABORAÇÃO: GISELIA PINHEIRO dOS REIS, 2016

Figura 8: Mapa de solo do município de Juquitiba - SP 
O exercício de classificação da declividade com base na metodologia utilizada pela EMBRAPA, 1979, é também adotado em estudos realizados pelo Ministério do Meio Ambiente para estabelecimento de normas legais que institui as áreas de preservação permanente como a Resolução CONAMA 303/2002 que dispõe sobre os parâmetros, definições e limites dessas áreas. Os mapas apresentam escalas diferentes, pois o fenômeno da declividade (figura 06) apresentou-se comprometido visualmente quando exibido em escala menor.

Todos os mapas elaborados a partir de imagens SRTM apresentam Coordenadas UTM pela inerência da característica de preservar os ângulos com mínimas distorções das áreas. No mapa de solo figura 08, elaborado a partir do cruzamento da base cartográfica do município com informações disponibilizadas por banco de dados INPE/EMBRAPA foi mantido as Coordenadas Geográficas por não comprometer a visualização da informação representada. Estas são características próprias do SIG QGIS utilizado na construção dos mapas presentes este trabalho.

As áreas representadas nos mapas correspondentes às cores em vermelho na figura 06 e em tons alaranjados na figura 07 indicam relevo mais acidentado com embasamento geológico em micaxistos com predominância de morros altos e médios, topografia forte ondulada, onde as declividades oscilam no intervalo de $20 \%$ a $30 \%$, e ultrapassam, com frequência, $40 \%$. Apresentam ainda vales são bem entalhados e a rede de drenagem é de alta densidade. Os tipos de solos correspondentes a estas áreas do município são representados na figura 08 e classificados como Latossolo Vermelho-Amarelo e material de alteração de consistência silto-arenosa. Em função destas características a área apresenta alta suscetibilidade a processos erosivos agressivos, com presença de sulcos e ravinas e possibilidade de movimentos de massa.

São registrados ainda formações geológicas do tipo granitos e gnaisses/migmatitos com ocorrência de morros altos e médios, com topografia médio a forte ondulada, onde as declividades predominantes oscilam entre $20 \%$ e 30\%, alcançando $40 \%$ na alta encosta até a linha de cumeada dos altos do Planalto de Ibiúna ou não ultrapassando $20 \%$ nas colinas da bacia do rio Sorocamirim. Os vales são relativamente entalhados e a rede de drenagem é de alta a média densidade. Os solos também possuem as mesmas características, classificados como Latossolo Vermelho-Amarelo e apresentam os mesmos fatores limitantes como suscetibilidade a processos erosivos e movimentos de massa. 
As menores altitudes são registradas em Trecho sobre aluviões: restritas planícies fluviais dos principais cursos d'água (Ribeirão das Laranjeiras, rio São Lourenço; e rios Sorocabuçu, Sorocamirim, Riberirão Pereiras), compostas por sedimentos inconsolidados e solos moles. Áreas planas, declividades quase nulas e de alta instabilidade morfodinâmica, sujeitas a inundações periódicas conforme representado na figura 07.

\subsubsection{Vegetação e uso e ocupação do solo}

O estudo do uso inadequado das terras é de grande importância, pois, boa parte das propriedades rurais apresentam algum tipo de uso conflitante com a terra. Toda a área de estudo encontra-se em domínio da Mata Atlântica, a fisionomia verificada predominantemente é de Floresta Ombrófila Densa. Ressalta-se a importância dos grandes fragmentos florestais da região para a fauna local e regional, pois, no conjunto, é integrante de corredores ecológicos de grande conectividade entre a serra do Mar (ao sul de Juquitiba), apesar da existência da rodovia Régis Bittencourt no município, que funciona como barreira física ao trânsito de animais silvestres.

Os corredores ecológicos entre remanescentes servem para aumentar o tamanho e as chances de sobrevivência de populações de diferentes espécies. Além de possibilitarem a recolonização com populações de espécies que foram reduzidas localmente, permite ainda a redução da pressão sobre o entorno das áreas protegidas (ARRUDA, 2003, p. 12). São definidos como:

um conjunto de ecossistemas que compõe uma eco/biorregião, conectando populações biológicas e áreas protegidas, interpretado como unidade de planejamento. Sua gestão visa conservar a biodiversidade, promover o uso sustentável dos recursos naturais e a distribuição equitativa das riquezas (IBAMA, 1998)

A legalidade dos corredores ecológicos se justifica porque viabiliza a dispersão de plantas e animais de uma reserva para outra, facilitando o fluxo de genes e a colonização das espécies mais vulneráveis à extinção, como as de baixa densidade populacional, que necessitam migrar sazonalmente. (PRIMACK \& RODRIGUES, 2001). Os mapas de vegetação (figura 09) e uso e ocupação do solo (figura 10) foram elaborados pela EMPLASA utilizando imagens do satélite comercial IKONOS que apresenta resolução espacial de 1 a 4 metros, o que permite maior identificação dos alvos imageados. Esse fato contribui para uma classificação mais precisa dos objetos mapeados. 


\section{COBERTURA VEGETAL NO MUNICÍPIO DE JUQUITIBA}

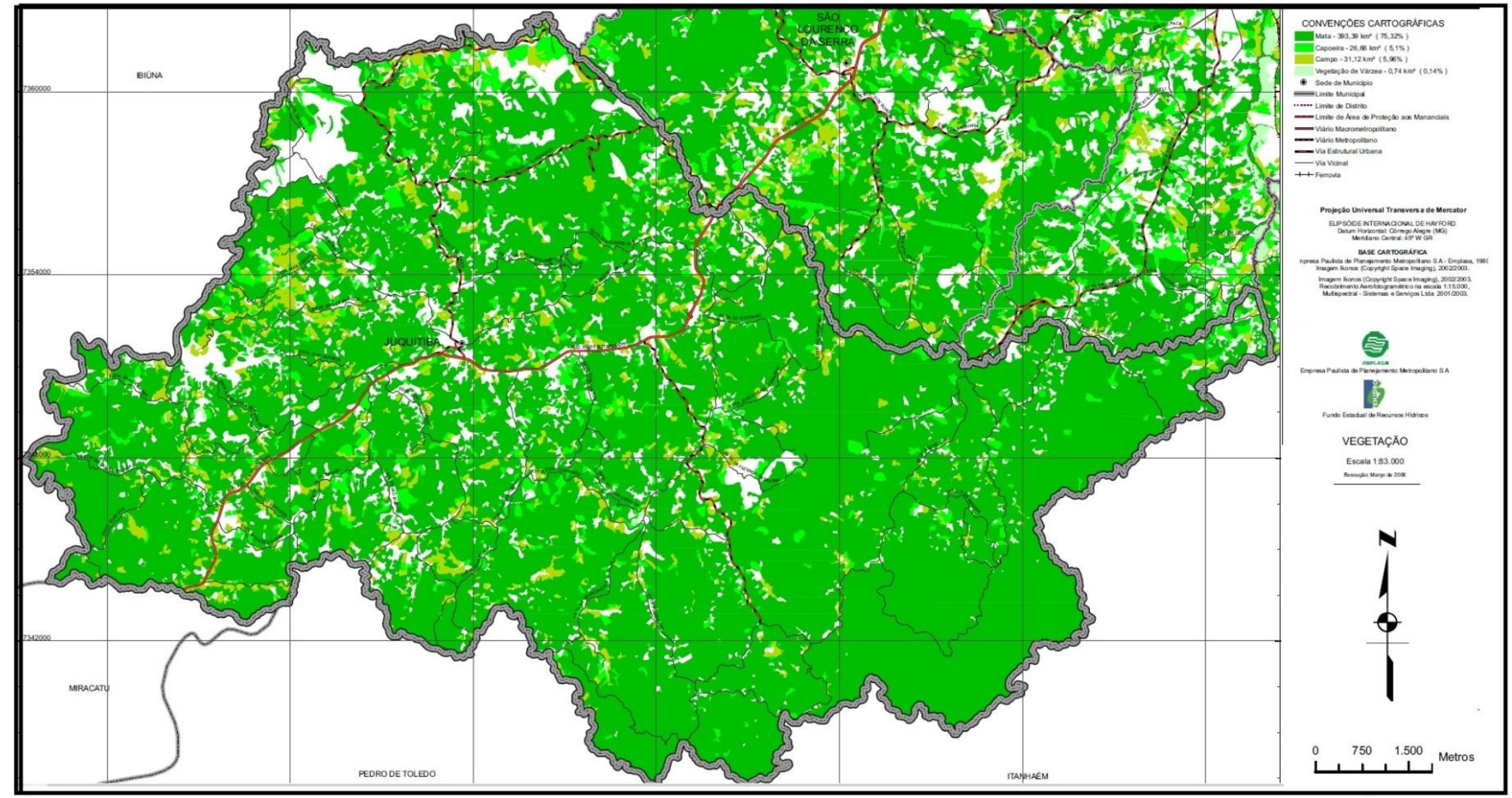

Figura 9 - Mapa de Cobertura Vegetal no município de Juquitiba - SP 
USO DO SOLO NO MUNICÍPIO DE JUQUITIBA

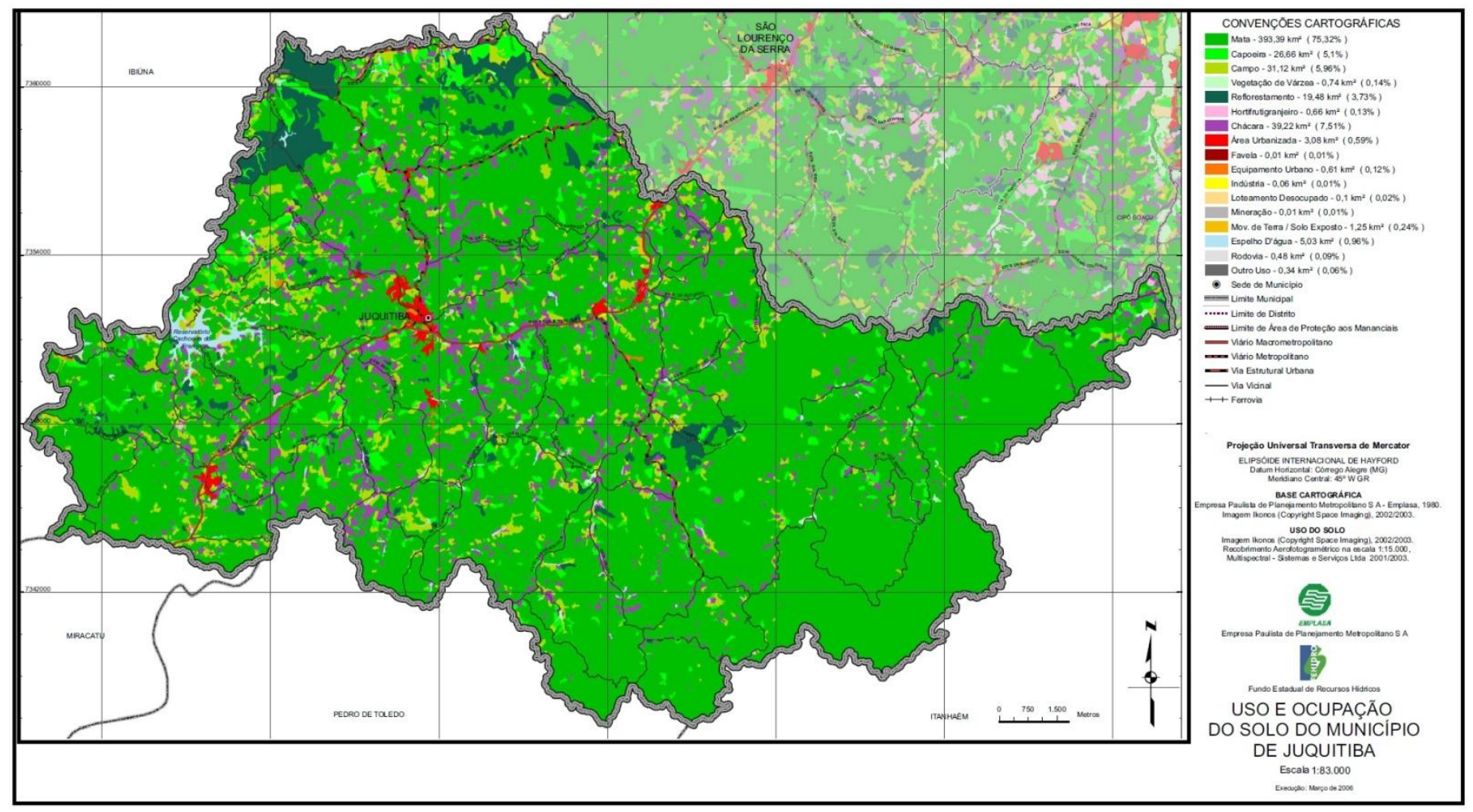

Figura 10 - Mapa de uso do solo no município de Juquitiba - SP 
As áreas indicadas no mapa como mata se caracterizam como áreas de vegetação de maior exuberância com destaque para a tipologia que predomina a região que são as Ombrófilas densas ou mata de encosta, a vegetação é composta por samambaias, bromélias, palmeiras, trepadeiras e epífitas (Figuras 11 e 12)

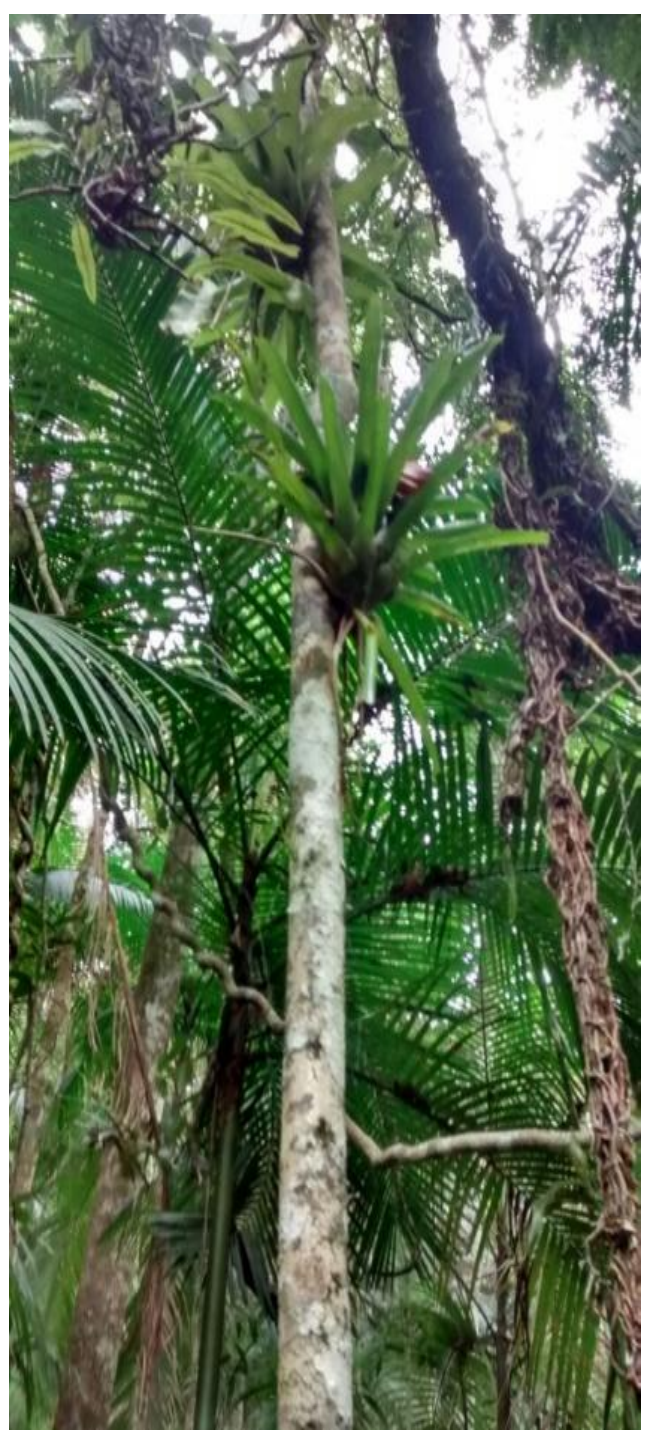

Figura 11: Bromélias -

Bairro das Laranjeiras 31/07/2016

Fonte: Gisélia Pinheiro dos Reis

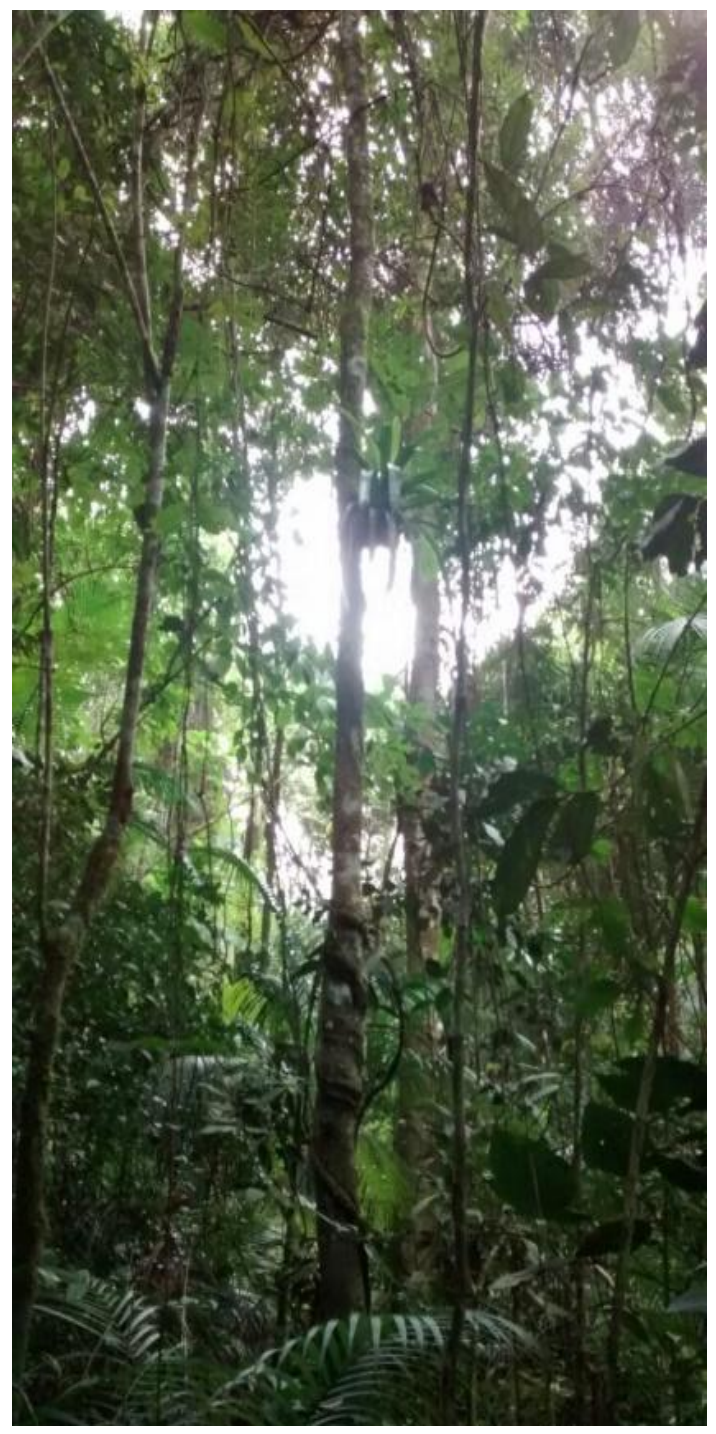

Figura 12: Vegetação densa

Bairro das Laranjeiras 31/07/2016

Fonte: Gisélia Pinheiro dos Reis 
A capoeira identificada na figura 09 é uma vegetação secundária composta por gramíneas e arbustos espaçados variando entre estágio inicial a médio de regeneração natural.

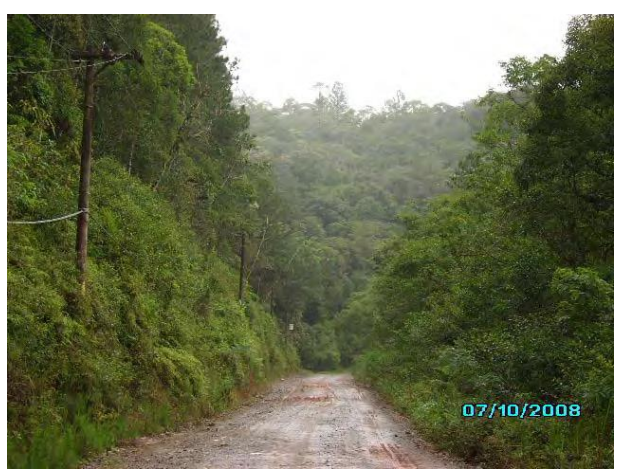

Figura 13: Capoeira + Mata no Alto Juquiá (RIMA, 2009, p. 83)

A vegetação de várzea (figura 09) corresponde a formações vegetais existentes em solos permanentemente encharcados, vegetação arbórea ou arbustivo-herbácea em área de várzea, com características predominantemente de estágio inicial em todas as bacias que passa por um processo natural de regeneração.

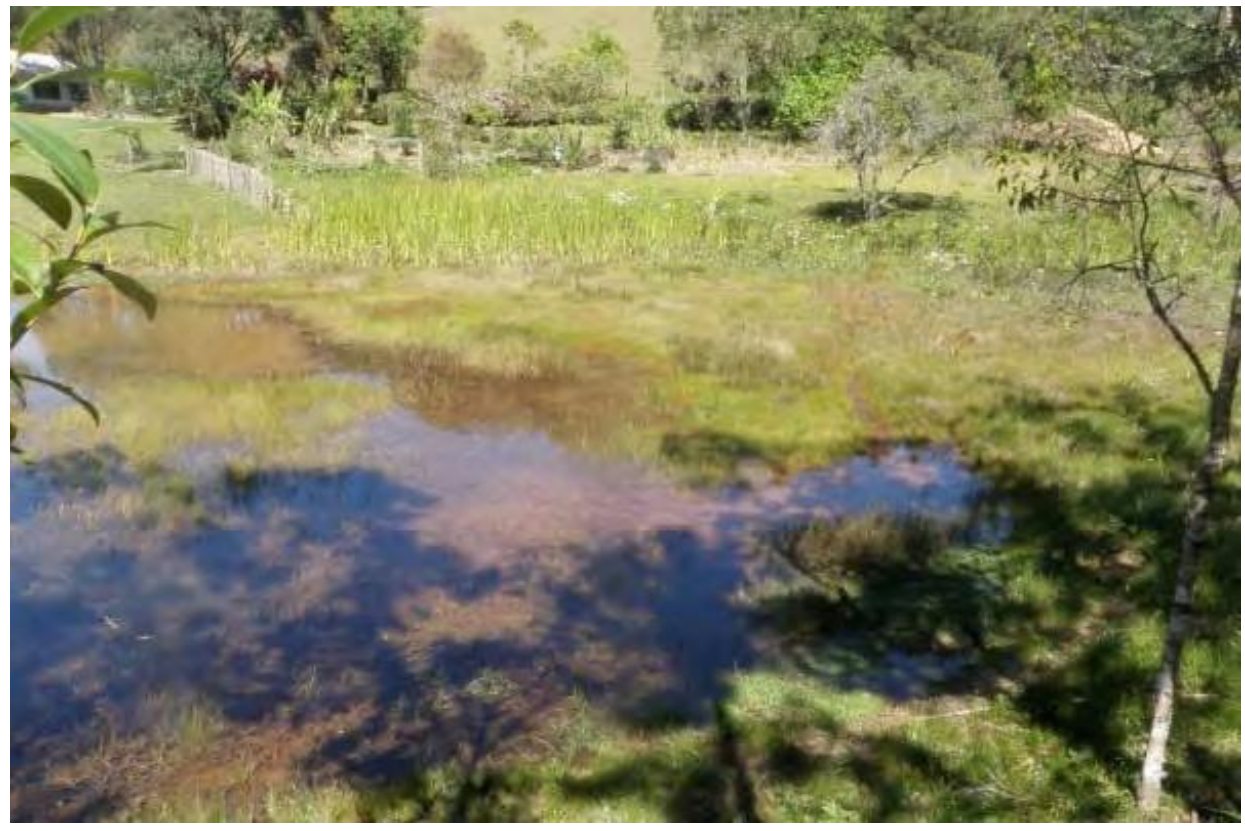

Figura 14: Vegetação de várzea - estrada dos padeiros (RIMA, 2009, p.83)

As formações florestais ciliares, que ocorrem às margens de alguns cursos d'água, estão sujeitas à inundação periódica, com características correspondentes à vegetação em estágio médio. 


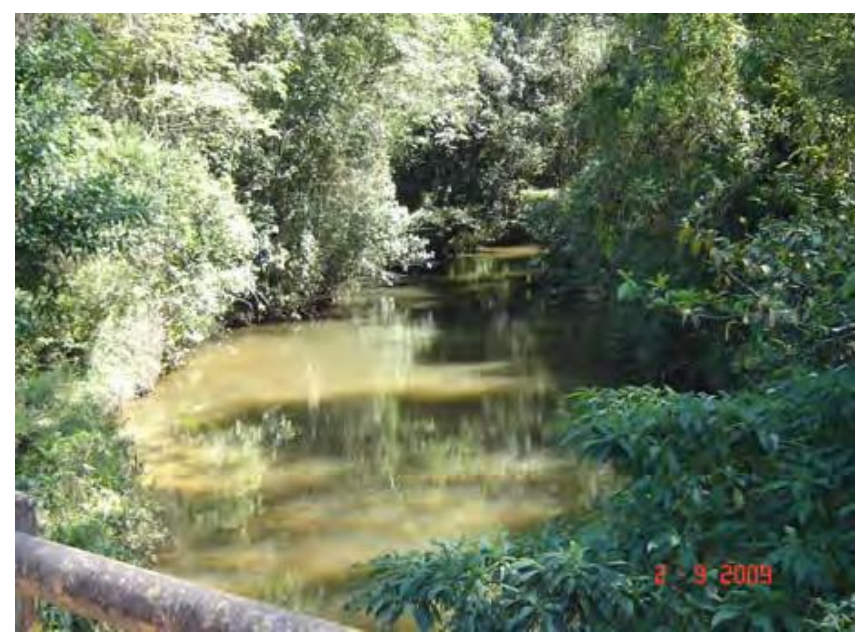

Figura 15: Mata Ciliar - Ribeirão das Laranjeiras (RIMA, 2009, p. 86)

A figura 10 apresenta os principais usos do solo no município com respectivos graus de antropização em $\mathrm{km}^{2}$ ou em porcentagem. A maior cobertura do solo no município de Juquitiba corresponde expressivamente à vegetação natural. Os usos antrópicos mais expressivos estão relacionados com Chácaras - 7,51\%, reflorestamento 3,73\% e área urbanizada $0,59 \%$. Os núcleos urbanos de maiores dimensões são a sede do município, os bairros de Barnabés e Jardim das Palmeiras.

\subsubsection{Bacias hidrográficas}

Os problemas relativos à água são comumente tratados pensando na bacia hidrográfica onde estão inseridos, cuja delimitação prevalece sobre os limites municipais e estaduais. Por isso, a Lei 9.433 (1997) estabelece como um dos princípios a definição da bacia hidrográfica como unidade territorial para implementação da Política Nacional de Recursos Hídricos. A adoção da bacia hidrográfica como unidade de planejamento é de aceitação universal, pois constitui um sistema natural, composto por um conjunto de terras drenadas por um rio principal e seus afluentes. Neste âmbito, na Geografia, as bacias hidrográficas são tratadas como unidades físicas importantes para o planejamento de desenvolvimento regional, uma vez que se constituem numa unidade geográfica espacial onde sociedade e natureza se integram, além de representar fácil reconhecimento e caracterização. 
A Resolução CONAMA 001/86, no artigo $5^{\circ}$ item III, se constitui num marco legal para o planejamento ambiental pensado sob a lógica do equilíbrio sistêmico das bacias hidrográficas ao declarar que "devem-se definir os limites da área geográfica a ser direta ou indiretamente afetada pelos impactos, denominada de área de influência do projeto, considerando, em todos os casos, a bacia hidrográfica na qual se localiza”.

De maneira geral, o conceito bacia hidrográfica associa-se a uma área geográfica natural, delimitada pelos pontos mais altos do relevo (espigões, divisores de água), dentro dos quais a água proveniente das chuvas é drenada superficialmente por um curso d'água principal até sua saída da bacia, no local mais baixo do relevo, que corresponde à foz desse curso d'água (EMBRAPA). GUERRA E CUNHA (1995) estabelecem que

Bacia hidrográfica ou bacia de drenagem é uma área da superfície terrestre que drena água, sedimentos e materiais dissolvidos em uma saída comum, num determinado ponto de um canal fluvial. O limite de uma bacia de drenagem é conhecido como divisor de drenagem ou divisor de águas.

O sistema de drenagem de uma bacia é constituído pelo rio principal e seus tributários; o estudo das ramificações e do desenvolvimento do sistema é importante, pois ele indica a maior ou menor velocidade com que a água deixa a bacia hidrográfica. $\mathrm{O}$ padrão de drenagem de uma bacia depende da estrutura geológica do local, tipo de solo, topografia e clima. Esse padrão também influencia o comportamento hidrológico da bacia. $\mathrm{O}$ escoamento superficial transporta compostos químicos, matéria orgânica e defensivos agrícolas que, além de causarem prejuízos diretos à produção agropecuária, também poluem os cursos d' água (PRUSKI, 2003).

Os canais de drenagem que formam a bacia estão interligados de forma sistêmica e hierarquizados. BERTONI E LOMBARDI NETO, (1999) utilizam o seguinte método para estabelecer a hierarquização fluvial:

1. Bacias de primeira ordem: são aquelas que não possuem tributários, ou seja, aquelas ligadas diretamente à nascente;

2. Bacias de segunda ordem: surgem da confluência de dois canais de segunda ordem e só recebem afluentes de primeira ordem;

3. Bacias de terceira ordem: surgem da confluência de dois canais de segunda ordem, podendo receber afluentes de ordenação inferior e assim sucessivamente.

A classificação possibilita o entendimento da dinâmica global do sistema hidrográfico e a identificação das unidades que o compõem. 
As bacias podem ser desmembradas em um número qualquer de sub-bacias, dependendo do ponto de saída considerado ao longo do seu eixo-tronco ou canal coletor. Cada bacia hidrográfica interliga-se com outra de ordem hierárquica superior, constituindo, em relação à última, uma sub-bacia. As bacias hidrográficas maiores são resultantes do conjunto de pequenas bacias.

A bacia hidrográfica, considerada como uma unidade de manejo ambiental, apresenta características intrínsecas, como relevo, tipo de solo e geologia que, em conjunto, convertemse em um atributo denominado vulnerabilidade natural. Inserindo-se nessa unidade a ação humana, ou seja, introduzindo-se fatores externos de ocorrência não natural, é possível avaliar o nível de degradação que produzem. Surge assim a possibilidade de aplicação de estudos de fragilidade ambiental em bacias hidrográficas, constituindo-se num importante instrumento no planejamento ambiental estratégico.

Avaliações da fragilidade ambiental, baseadas em fatores como o solo, o potencial de erosão das chuvas, a declividade e a cobertura vegetal, são necessárias ao planejamento

ambiental. O conhecimento dos níveis de fragilidade presentes em uma bacia hidrográfica, por meio da integração de diversas variáveis que interferem nas potencialidades dos recursos naturais, possibilita compreender a realidade e obter uma visão mais clara sobre quais são as opções mais adequadas para o uso da terra (SPÖRL, 2001).

O manejo integrado de bacias hidrográficas visa tornar compatível a produção com preservação ambiental, buscando adequar as interferências antrópicas às características biofísicas dessas unidades naturais (ordenamento do uso/ocupação da paisagem, observadas as aptidões de cada segmento e sua distribuição espacial na respectiva bacia hidrográfica), sob gestão integrativa e participativa, de forma que sejam minimizados impactos negativos e se garanta o desenvolvimento sustentável.

O conceito de manejo integrado de bacias hidrográficas pressupõe planejar e implantar as práticas conservacionistas considerando-se o contexto das bacias e não nas propriedades isoladas. A unidade de planejamento passa a ser a bacia hidrográfica.

Portanto, os trabalhos de manejo de bacias hidrográficas devem ser iniciados, preferencialmente, nas bacias de menor porte, inseridas no município. A utilização da subbacia municipal tem sua justificativa no fato de ser em nível local que os problemas se manifestam. As pessoas residentes nele são, ao mesmo tempo, causadoras e vítimas de partes dos problemas. São elas que convivem com eles e as que mais têm interesse em resolvê-los. 
Por outro lado, é no município que toda a estrutura administrativa é mais de perto sentida e sensível às reivindicações.

O planejamento estratégico por bacias hidrográficas se define, fundamentalmente, nos diagnósticos das sub-bacias efetuados pelo poder público. O balanceamento entre os elementos culturais, sociais, econômicos e ecológicos na elaboração dos "mapas" das bacias e a consequente priorização das ações varia de acordo com a natureza das análises feitas.

Para o planejamento de bacias hidrográficas é necessária uma visão integrada da ação antrópica sobre os recursos hídricos, ou seja, numa mesma bacia hidrográfica pode haver, concomitantemente, uma pressão urbana e rural para a qual se dispõem de técnicas e práticas específicas que visam a conservação e/ou a preservação dos recursos hídricos.

As figuras 16 e 17 foram elaboradas em SIG QGIS através do plugin GRASS com o mosaico de imagens SRTM Topodata. As sub-bacias foram mapeadas com auxilio da carta topográfica do município Juquitiba, onde cada topônimo corresponde a um canal de drenagem de maior expressividade presente a carta topográfica. Estes mapas apresentam a diversidade de recursos hídricos do município, bem como aponta para responsabilidade do poder público e da sociedade civil em manter o equilíbrio natural por meio da utilização e exploração racional desse recurso. As sub-bacias de maior relevância para o município correspondem às: Ribeirão das Laranjeiras, rio São Lourenço, rio Juquiá e Juquiá-Guaçu conforme figuras 16 e 17 respectivamente. 


\section{SUB-BACIAS HIDROGRÁFICAS NO MUNICÍPIO DE JUQUITIBA}

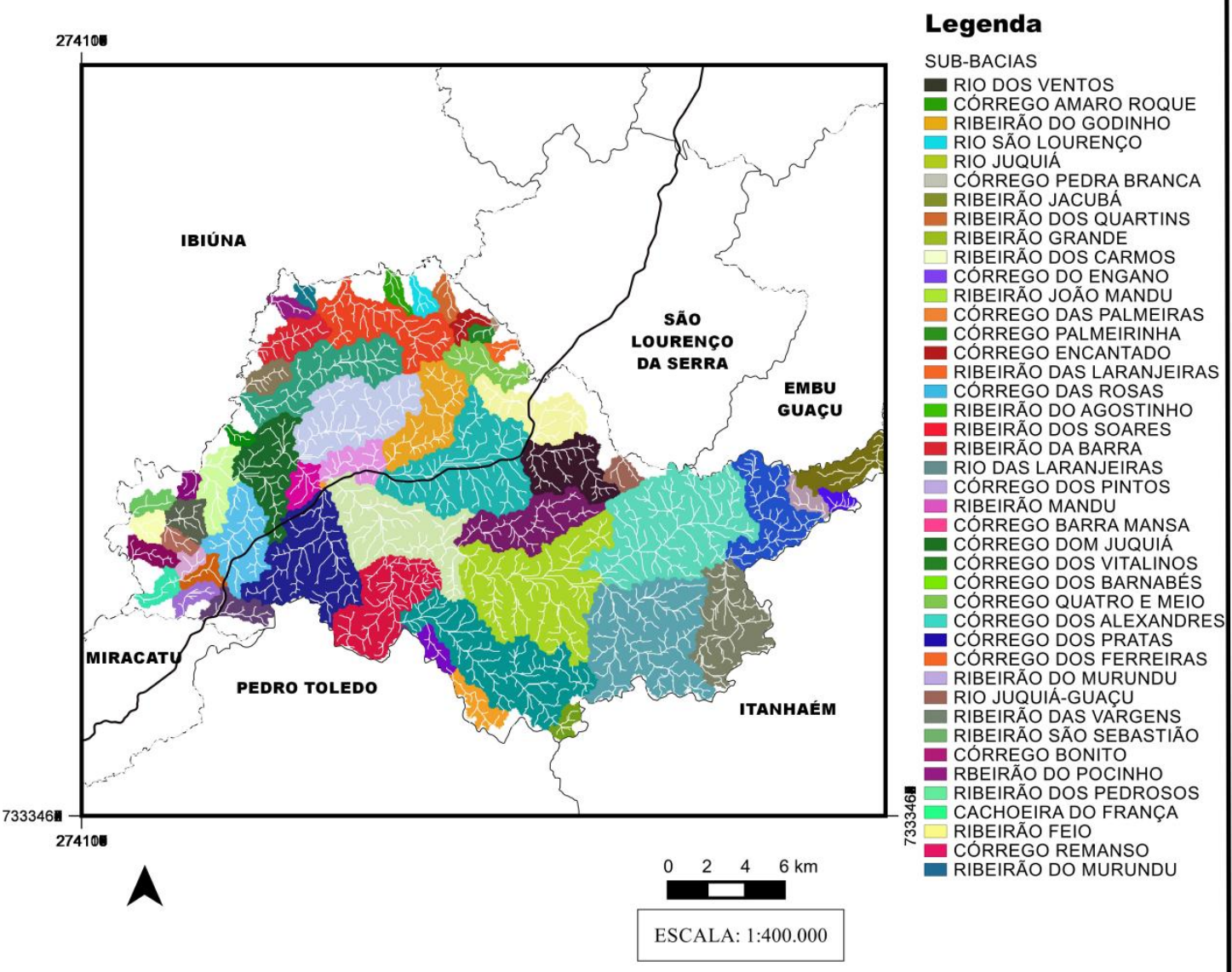

Projeção Universal Transversa de Mercator

Datum Horizontal: SIRGAS 2000 - Fuso $23^{\circ} \mathrm{S}$

Fonte: Mapa Digital do Estado de São Paulo

Elaboração: Gisélia Pinheiro dos Reis, 2016

Figura 16: Mapa das Sub-bacias hidrográficas no município de Juquitiba - SP 


\section{REDE DE DRENAGEM DO MUNICÍPIO DE} JUQUITIBA

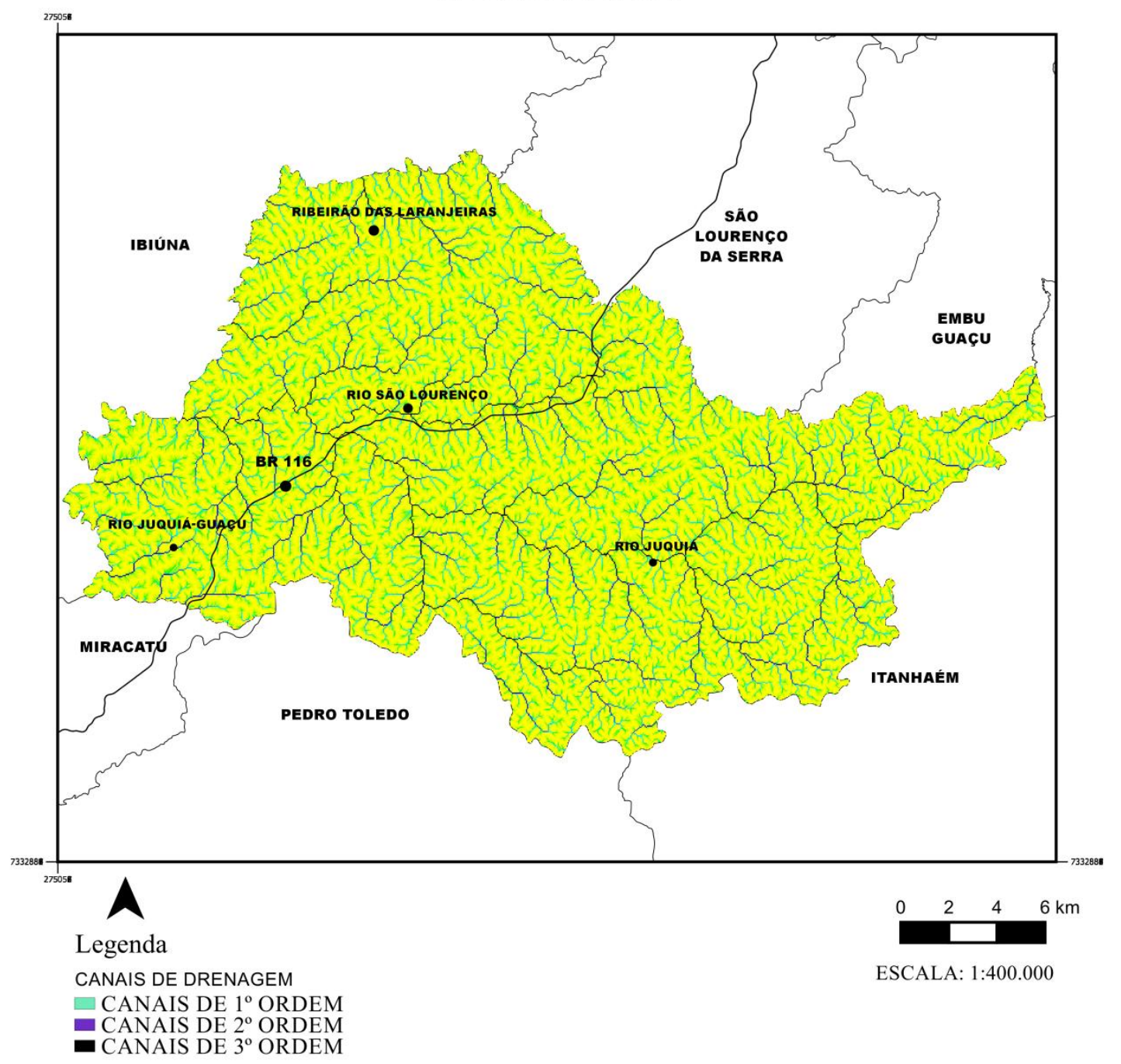

Projeção Universal Transversa de Mercator Datum Horizontal: SIRGAS 2000 - Fuso $23^{\circ} \mathrm{S}$

Fonte: Mapa Digital do Estado de São Paulo

Elaboração: Gisélia Pinheiro dos Reis, 2016

Figura 17: Rede de drenagem do município de Juquitiba - SP

A análise destes mapas (figuras 16 e 17) conduz a uma reflexão sobre a intrínseca relação entre os diferentes canais de drenagem que formam as sub-bacias no município. Estas 
figuras traduzem a riqueza em recursos hídricos que aflora sobre o território de Juquitiba. Ressalta a necessidade de manter um planejamento adequado das atividades a serem desenvolvidas para que estas não impactem de forma negativa causando a poluição dos corpos hídricos, tornando-os impróprios para o consumo humano, ou comprometendo o desenvolvimento das atividades econômicas que deles dependem.

A figura 17 destaca quatro importantes canais de drenagem, que são O Ribeirão das Laranjeiras localizado ao norte do município, apresenta-se densamente caudaloso e com vegetação ciliar exuberante. O rio São Lourenço, que também é destaque no município, recebe esse nome quando o rio São Lourencinho se junta com o ribeirão Pedreado.

Juquitiba é atravessada pelo Rio São Lourenço na própria área urbana. Logo mais a jusante aflui ao rio Juquiá pela margem direita. Vários pequenos afluentes pela margem esquerda e direita são encontrados nessa área. A seção do Rio São Lourenço na cidade corresponde a uma área de drenagem com cerca de $190 \mathrm{~km}^{2}$. Em decorrência do contato direto deste rio com o núcleo urbano, torna-se necessário planejamento incipiente sobre o controle da ocupação na várzea dos córregos, leito maior visto que, estas áreas são submetidas periodicamente à inundação, bem como, evitar a excessiva impermeabilização que causa um excedente de escoamento superficial, tendo em vista que este município pode proporcionar efeitos a jusante na bacia. A contaminação de suas águas ocorre, sobretudo por dejetos ou resíduos sólidos carreados para suas águas nos intensos períodos de chuva.

O rio Juquiá localizado na porção leste do município tem suas águas aproveitadas para atividades turísticas com potencial para práticas esportivas, de lazer e de belezas cênicas. Também às suas margens são instalados empreendimentos imobiliários, como infraestrutura que atendam as necessidades turísticas do município, se configurando atividades impactantes quando não planejadas de forma adequada respeitando os limites e potencialidade do meio natural. Sua importância da preservação transcende os limites municipais em função da política nacional de recursos hídricos que institui os Comitês de gerenciamento das bacias hidrográficas. A sub-bacia Juquiá-Guaçu no oeste do município é próxima ao bairro de Barnabés. Com suas corredeiras também é propício ao desenvolvimento de atividades relacionadas com as práticas esportivas como rafting e canoagem. 


\title{
5.2.2.4 Zoneamento ambiental
}

O zoneamento ambiental é um instrumento da Política Nacional do Meio Ambiente Lei Federal nº 6938/81 e consiste na divisão de determinado território em áreas, respeitando suas características ambientais e socioeconômicas. Pelo zoneamento ambiental são instituídos diferentes tipos de zonas, para as quais o Poder Público estabelece regimes especiais de uso com o objetivo de melhorar e recuperar a qualidade ambiental e do bem-estar da população. Posteriormente, com a regulamentação do Decreto Federal no 4.297/2002, o termo evolui para Zoneamento Ecológico-Econômico (ZEE), e se define como:

instrumento de organização do território a ser obrigatoriamente seguido na implantação de planos, obras e atividades públicas e privadas" estabelecendo "medidas e padrões de proteção ambiental" com vistas à "assegurar a qualidade ambiental, dos recursos hídricos e do solo e a conservação da biodiversidade, garantindo o desenvolvimento sustentável e a melhoria das condições de vida da população.

O Zoneamento Ambiental pode ser entendido como uma proposta metodológica de uso do território segundo suas potencialidades e vocações sócio naturais. Essa concepção de Zoneamento o torna muito utilizado pelos planejadores ambientais enquanto um importante procedimento de ordenação territorial.

Por meio do Zoneamento Ambiental observa-se um conhecimento efetivo das potencialidades e fragilidades da paisagem, elaborando cenários, apresentados sob as variadas formas de representação cartográficas: mapas, matrizes, diagramas ou índices. Para cada zona atribui-se um conjunto de normas específicas, dirigidas para o desenvolvimento de atividades e para a conservação do meio. Estas normas definem políticas de orientação, consolidação e revisão de alternativas existentes ou formulação de novas alternativas de ação (ZACHARIAS, 2006). Nesta perspectiva, Santos (2004, p. 133) esclarece que

\begin{abstract}
...o Zoneamento é, antes de tudo, um trabalho interdisciplinar predominantemente qualitativo, mas que lança mão de uso de análise quantitativa, dentro de enfoques analítico e sistêmico. O enfoque analítico refere-se aos critérios adotados a partir do inventário dos principais temas, enquanto que o enfoque sistêmico refere-se à estrutura proposta para a integração dos temas e aplicação dos critérios, resultando em síntese do conjunto de informações.
\end{abstract}

Através do planejamento com participação do governo, o setor privado e a sociedade civil estabelecem estratégias e alternativas que serão adotadas para que se alcance o objetivo maior desse instrumento que é a promoção do desenvolvimento sustentável nas atividades econômicas que são espacialmente distribuídas considerando sua importância ecológica, as 
potencialidades, limitações e fragilidades dos ecossistemas. Essa política estabelece vedações, restrições e alternativas de exploração do território e pode determinar quais atividades são incompatíveis com suas diretrizes gerais de modo a realocá-las. A participação da sociedade civil no estabelecimento de critérios e na indicação de suas necessidades é fundamental para que o zoneamento ambiental possa contribuir, de maneira adequada, para qualidade de vida da população local e minimizar os conflitos que a localização de um empreendimento possa gerar. O zoneamento pode ser considerado como um "todo sistêmico", em que se combinam a natureza, a economia, a sociedade e a cultura.

A instalação das atividades econômicas pressupõe um estudo obedecendo aos critérios do binômio tipologia-localização ao identificar as características inerentes ao empreendimento e observar a capacidade de suporte do ambiente para recebê-lo, o que implica em um Estudo de Impacto Ambiental (EIA) como determina a Política Nacional do Meio Ambiente.

A capacidade de suporte do ambiente para implantação de empreendimentos e desenvolvimento de atividades humanas está pautada nas características dos meios físico, biológico e antrópico o que conferem, para cada parcela de território, maior ou menor potencial (ou, em oposição, menor ou maior restrição) para cada tipo de ocupação. A visão sistêmica propicia a análise de causa e efeito, pois analisa a combinação de fatores tais como relevo, solos, formações geológicas, recursos hídricos, entre outros e determina a capacidade (ou aptidão) do meio em suportar certas atividades humanas de forma que os impactos dessas atividades estejam de acordo com as determinações legais (ZACHARIAS, 2006).

A Constituição Federal de 1988 delegou ao Poder Público municipal, através do Plano Diretor, a promoção do adequado ordenamento territorial (zoneamento urbano) mediante planejamento e controle do uso, do parcelamento e da ocupação do solo urbano, visando à proteção dos recursos naturais e qualidade de vida da população. 


\section{ZONEAMENTO AMBIENTAL DO MUNICÍPIO DE JUQUITIBA}

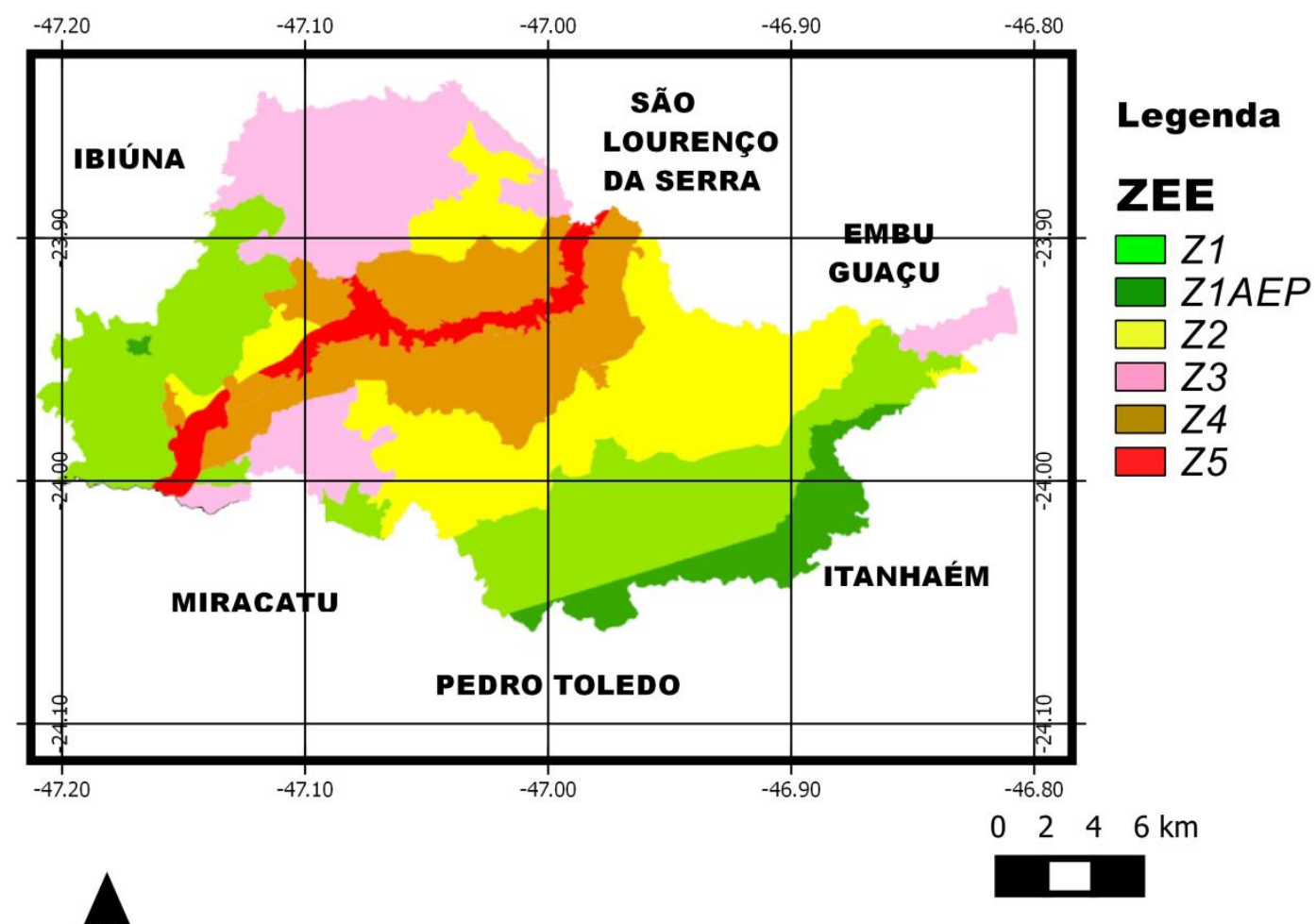

ESCALA: 1:400.000

Sistema de Coordenada Referência

Datum Horizontal: SIRGAS 2000

Fonte: Gerenciamento Costeiro do Vale do Riebira - SEMA, 2012 Adaptação: Gisélia Pinheiro dos Reis, 2016

Figura 18: Zoneamento Ambiental do município de Juquitiba - SP 


\begin{tabular}{|c|c|c|}
\hline & CARACTERÍSTICAS & USOS E ATIVIDADES PERMITIDAS \\
\hline $\mathrm{Z1}$ & $\begin{array}{l}\text { - Áreas contínuas de } \\
\text { vegetação nativa e fauna } \\
\text { associada; } \\
\text { - Predomínio de áreas de } \\
\text { preservação permanente } \\
\text { ou de risco geotécnico; } \\
\text { - Ocorrência de Unidades de } \\
\text { Conservação de Proteção } \\
\text { Integral, Reservas } \\
\text { Particulares do Patrimônio } \\
\text { Natural, e nas Áreas } \\
\text { Naturais Tombadas, Terras } \\
\text { Indígenas e Zonas de Vida } \\
\text { Silvestre em Áreas de } \\
\text { Proteção Ambiental; } \\
\text { Áreas preservadas } \\
\text { contíguas às Unidades de } \\
\text { Conservação; } \\
\text { Desenvolvimento de } \\
\text { atividades compatíveis } \\
\text { com a preservação e a } \\
\text { conservação; } \\
\text { Áreas de mananciais de } \\
\text { interesse para o } \\
\text { abastecimento. }\end{array}$ & $\begin{array}{l}\text { - Pesquisa científica; } \\
\text { - } \text { Educação ambiental; } \\
\text { naturais, condicionado à elaboração de } \\
\text { plano específico, incluindo o } \\
\text { processamento artesanal e comercialização } \\
\text { dos produtos decorrentes dessa atividade; } \\
\text { - Empreendimentos de ecoturismo que } \\
\text { mantenham as características ambientais } \\
\text { da zona; } \\
\text { - Pesca artesanal; } \\
\text { - Ocupação humana de baixo efeito } \\
\text { impactante, conforme definido no artigo } \\
49 \text { deste Decreto, de forma a manter as } \\
\text { características da zona; } \\
\text { - Sistema Agroflorestal que não prejudique } \\
\text { a função ambiental da área. }\end{array}$ \\
\hline Z1AEP & $\begin{array}{l}\text { - Áreas sob regime de estrita } \\
\text { proteção e administração } \\
\text { autônoma definida em Lei: } \\
\text { - Unidades de Conservação } \\
\text { do grupo de proteção } \\
\text { integral; } \\
\text { - Terras indígenas } \\
\text { homologadas ou com } \\
\text { processo demarcatório } \\
\text { autorizado pelo órgão } \\
\text { competente; } \\
\text { - Reservas Particulares do } \\
\text { Patrimônio Natural; }\end{array}$ & $\begin{array}{l}\text { - Na Lei Federal no 9.985/2000, } \\
\text { assegurando-se às populações tradicionais } \\
\text { residentes na área, as condições e os meios } \\
\text { necessários p/ satisfação de suas } \\
\text { necessidades materiais, sociais e culturais; } \\
\text { - No diploma de criação da Unidade de } \\
\text { Conservação e respectivo Plano de } \\
\text { Manejo, na existência deste; } \\
\text { - Na regulamentação específica, no caso das } \\
\text { terras indígenas. }\end{array}$ \\
\hline
\end{tabular}




\begin{tabular}{|c|c|c|}
\hline $\mathrm{Z} 2 \mathrm{~T}$ & 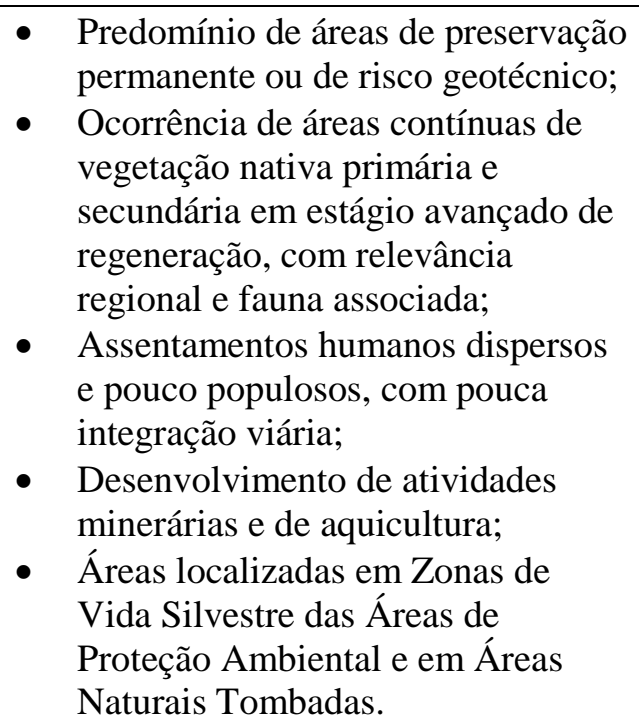 & $\begin{array}{l}\text { - Além daqueles previstos para } \\
\text { a Z1: } \\
\text { Aquicultura de baixo } \\
\text { impacto, incluindo unidades } \\
\text { integradas de } \\
\text { beneficiamento, } \\
\text { processamento e } \\
\text { comercialização dos produtos } \\
\text { decorrentes dessa atividade; } \\
\text { - Mineração. }\end{array}$ \\
\hline Z3T & $\begin{array}{l}\text { - Ecossistema primitivo parcialmente } \\
\text { modificado; } \\
\text { - Predominância de atividades } \\
\text { agrossilvipastoris; } \\
\text { - Assentamentos humanos com } \\
\text { características rurais, interligados } \\
\text { localmente, atendidos com } \\
\text { equipamentos de infraestrutura, tais } \\
\text { como escolas, praças e postos de } \\
\text { saúde; } \\
\text { - Solos com aptidão agropecuária. }\end{array}$ & $\begin{array}{l}\text { - Além daqueles previstos para } \\
\text { a Z1 e Z2: } \\
\text { Agropecuária, silvicultura e } \\
\text { aquicultura incluindo } \\
\text { unidades integradas de } \\
\text { beneficiamento, } \\
\text { armazenagem, } \\
\text { processamento e } \\
\text { comercialização dos produtos } \\
\text { decorrentes dessas } \\
\text { atividades; } \\
\text { Comércio e serviços, que não } \\
\text { alterem as características } \\
\text { ambientais; } \\
\text { Implantação de } \\
\text { equipamentos de suporte às } \\
\text { atividades educacionais, } \\
\text { esportivas, assistenciais, } \\
\text { saúde, de comunicação, } \\
\text { religiosas e culturais; } \\
\text { Assentamentos humanos c/ } \\
\text { características rurais, } \\
\text { inclusive atendendo as } \\
\text { demandas dos programas de } \\
\text { habitação de interesse social; } \\
\text { Produção de artefatos de } \\
\text { cimento, concreto e } \\
\text { cerâmica. } \\
\text { Novos critérios para o } \\
\text { detalhamento das atividades } \\
\text { de beneficiamento dos } \\
\text { produtos agrossilvipastoris, } \\
\text { considerando o porte dos } \\
\text { empreendimentos e potencial } \\
\text { poluidor, poderão ser } \\
\text { definidos por resolução. }\end{array}$ \\
\hline
\end{tabular}




\begin{tabular}{|c|c|c|}
\hline Z3AEP & $\begin{array}{l}\text { Áreas de uso agropecuário } \\
\text { que se encontram sob } \\
\text { regime de estrita proteção } \\
\text { e administração autônoma } \\
\text { definida em Lei, } \\
\text { consistentes em: } \\
\text { Reservas Extrativistas e as } \\
\text { Reservas de } \\
\text { Desenvolvimento } \\
\text { Sustentável, a que alude a } \\
\text { Lei Federal no } 9.985 \text {, de } 18 \\
\text { de julho de } 2000 ;\end{array}$ & $\begin{array}{l}\text { - Aquicultura de baixo impacto; } \\
\text { - Beneficiamento, processamento artesanal } \\
\text { e comercialização de produtos decorrentes } \\
\text { das atividades de subsistência das } \\
\text { populações; } \\
\text { - Usos previstos na Lei Federal no } \\
\text { 9.985/2000, no diploma de criação da UC } \\
\text { e respectivos Planos de Manejo ou Planos } \\
\text { de Utilização. }\end{array}$ \\
\hline ZAT & $\begin{array}{l}\text { - Ecossistema primitivo } \\
\text { significativamente } \\
\text { modificado; } \\
\text { - Assentamentos humanos, } \\
\text { com características } \\
\text { urbanas descontínuas com } \\
\text { infraestrutura incompleta; } \\
\text { - Áreas com potencial para } \\
\text { expansão urbana; Áreas } \\
\text { com infraestrutura urbana } \\
\text { planejada ou em fase de } \\
\text { instalação }\end{array}$ & $\begin{array}{l}\text { - Além daqueles previstos para a Z1, Z2 e } \\
\text { Z3: } \\
\text { - } \text { Ocupação para fins urbanos; } \\
\text { - Armazenamento, embalagem, transporte e } \\
\text { distribuição de produtos e mercadorias, } \\
\text { exceto de produtos perigosos; } \\
\text { - Empreendimentos comerciais e de } \\
\text { serviços de impacto ambiental local. } \\
\text { - Empreendimentos comerciais e de } \\
\text { serviços de impacto ambiental local -a } \\
\text { implantação planejada de obras de } \\
\text { transporte, obras hidráulicas de } \\
\text { saneamento, operações urbanas } \\
\text { consorciadas, cemitérios e linhas de } \\
\text { transmissão e subestações associadas, } \\
\text { - É admitido o parcelamento do solo } \\
\text { urbano, respeitado o disposto nos Planos } \\
\text { Diretores e instrumentos de ordenamento } \\
\text { territorial municipais. }\end{array}$ \\
\hline$\overline{\mathrm{Z3AEP}}$ & $\begin{array}{l}\text { - Áreas de uso agropecuário } \\
\text { que se encontram sob } \\
\text { regime de estrita proteção } \\
\text { e administração autônoma } \\
\text { definida em Lei, } \\
\text { consistentes em: } \\
\text { - Reservas Extrativistas e as } \\
\text { Reservas de } \\
\text { Desenvolvimento } \\
\text { Sustentável, a que alude a } \\
\text { Lei Federal no } 9.985 \text {, de } 18 \\
\text { de julho de } 2000 ;\end{array}$ & $\begin{array}{l}\text { - Aquicultura de baixo impacto; } \\
\text { - Beneficiamento, processamento artesanal } \\
\text { e comercialização de produtos decorrentes } \\
\text { das atividades de subsistência das } \\
\text { populações; } \\
\text { - Usos previstos na Lei Federal no } \\
\text { 9.985/2000, no diploma de criação da UC } \\
\text { e respectivos Planos de Manejo ou Planos } \\
\text { de Utilização. }\end{array}$ \\
\hline
\end{tabular}


No município de Juquitiba o Zoneamento Ambiental representado na figura 18 reflete as condições naturais do município. Os estudos implementados na região para este fim identificaram o equilíbrio sistêmico existente entre os elementos e ampararam-se na legislação vigente que rege a proteção dos recursos naturais, sobretudo em função do remanescente de floresta.

A figura 18 elaborada com dados da Secretaria Estadual do Meio Ambiente Gerenciamento Costeiro do Vale do Ribeira tem por finalidade analisar a distribuição espacial das zonas ambientais do município e quais atividades podem ser desenvolvidas nestas determinadas áreas. Esta figura evoca todo o potencial ambiental que se concentra no município seja em relação aos recursos hídricos, a vegetação ou as condições morfoestruturais. Aponta para a necessidade da manutenção do equilíbrio dinâmico entre os recursos bióticos e abióticos, de acordo com os princípios do Geossistema.

O estabelecimento destas zonas partiu do conhecimento efetivo das condições naturais, explorando seus limites e potencialidades a fim de favorecer o planejamento das atividades econômicas a serem desenvolvidas no município, conforme observa a tabela que estabelece os usos e diretrizes. É importante atentar para o caráter holístico destas normas, pois o equilíbrio sistêmico é determinado por práticas planejadas que envolvem todos os seres vivos, inclusive o ser humano que tem sua sobrevivência diretamente relacionada com a exploração dos recursos naturais. Neste aspecto existe uma tensão perturbadora, pois o uso tem que ser racional, sustentável e equilibrado, sob pena de causar sua escassez e comprometer a qualidade destes para as gerações próximas. A figura 18 põe em evidência a necessidade de transformar o planejamento ambiental em uma práxis e não meramente em um documento que visa atender somente as exigências da legislação que incide sobre o município. 


\section{Considerações finais}

A Cartografia é uma ciência que favorece a análise dos fenômenos espaciais de forma correlacionada, por isso se traduz num importante instrumento de leitura do espaço geográfico nos dias atuais. Enquanto um instrumento de descoberta e de comunicação, evoluiu atrelada ao poder econômico vigente, sempre a serviço de um saber ou de uma ação estratégica de domínio dos diferntes territórios, principalmente sob influência das nações europeias. A conjuntura social, política e econômica da sociedade moderna tem exigido leituras mais complexas do espaço geográfico e a Cartografia Temática expressa fenômenos múltiplos, fruto de conhecimentos interdisciplinares e tem seus métodos na atualidade cada vez mais aperfeiçoados pelo uso das tecnologias aplicadas como o uso dos SIGs e do Sensoriamento Remoto.

A Geografia possui intríseca relação com a Cartografia uma vez que ambas se preocupam com a representação dos fenômenos espaciais. Evoluíram concomitantemente e beberam nas mesmas fontes para consolidarem-se enquanto saberes científicos. Outro caminho metodológico que tem contribuído para a Geografia ampliar sua base de análise é o Geossistema que se solidificou a partir da Teoria Geral dos Sistemas. Esse paradigma privilegia o conhecimento integrado e inter-relacionado do meio ambiente no qual o homem deixa de ser espectador para ser partícipe que atua diretamente através das intervenções que realiza no equilíbrio dinâmico da natureza, pondo fim à dicotomia que permeou os debates geográficos desde os seus primórdios.

De acordo com Tricart, a Teoria dos Sistemas constitui a melhor concepção científica para os estudos ambientais porque analisa os recursos que compõem o extrato geográfico de forma holística. Essa concepção metodológica subsidia o planejmento ambiental, importante instrumento de gestão dos recursos naturais. A Cartografia Temática também se vale da teoria sistêmica para representar cenários ambientais em transformações que ocorrem no espaço geográfico na forma de síntese ou de análise porque considera a inter-relação entre os diferentes componentes do estrato geográfico.

As representações temáticas presentes neste trabalho buscaram, no estudo dos aspectos ambientais do município de Juquitiba, elucidar a importância dos seus recursos naturais no cenário de crise ambiental, que deixa de ser especulação sensacionalista e já atinge a todos em esfera municipal, estadual e federal de forma paradoxal: a escassez de água, apesar da abundância desse recurso, preservação da maior diversidade biológica do planeta reduzida em $7 \%$ no território nacional e irregularidades das chuvas num bioma tropical. 
É importante ressaltar que os problemas decorrentes dos desequilíbrios da natureza afetam diretamente o ser humano, sendo que os pobres são os mais atingidos. Pressionados a ocupar áreas de risco em função do valor da terra, são vítimas de alagamentos e movimentos de massa. Quando ocorre acesso ao sistema de saneamento básico, sofrem com os elevados preços dos serviços que seguem a lógica do sistema capitalista. Diante dos cenários que se apresentam, torna-se urgente que as leis que visam zelar pelo patrimonio ambiental presente no município de Juquitiba sejam efetivamente praticadas e fiscalizadas. Que o poder público garanta o planejamento ambiental que privilegie o uso racional dos recursos naturais, respeitando o equilíbrio dinâmico do meio ambiente e que contemple a reconciliação entre o ser humano e a natureza, de forma que ocorra o pleno desenvolvimento econômico e social, que reflita em melhores condições de vida para população local num ambiente saudável e equilibrado.

Os resultados obtidos permitem concluir que a Cartografia Temática, contribui para analise integrada dos fenômenos que ocorrem na superfície terrestre, corroborando com a teoria do Geossistema que ampara as pesquisas ambientais desde a sua consolidação enquanto paradigma teórico-metodologico. Os mapas temáticos construídos com o auxílio das tecnologias de informação geográfica contribuem significativamente no desenvolvimento de projetos de planejamento ambiental, ao propor o uso adequado e racional dos recursos naturais disponíveis, possibilitando preservar e melhorar a qualidade ambiental do município.

Os cenários ambientais representados através dos mapas do município contribuíram para apresentar as características naturais da região, como também para compreender a complexidade das relações intrínsecas que existem entre os diferentes elementos que compõe o extrato geográfico, o que desperta para a importância da continuidade dos estudos a fim de aprimorar a relação do ser humano com a natureza, superando a lógica da exploração descontrolada implantada desde os períodos da colonização.

O município de Juquitiba possui um aparato legal que garante o uso sustentável dos recursos naturais, porém mediante os problemas levantados neste estudo, principalmente os relacionados ao uso e ocupação do solo, verificou-se que a prática do planejamento ambiental e as ações relacionadas à proteção dos recursos naturais devem estar na ordem do dia, garantindo a vigência da lei através da educação ambiental, despertando nos moradores da região uma consciência ecológica, além da fiscalização das práticas, principalmente as relacionadas às atividades econômicas. 
Estas foram algumas das contribuições teóricas e metodológicas que favorecem iniciativas para o planejamento ambiental no município de Juquitiba e que despertam para a importância de novas posturas diante do uso dos recursos naturais, pois os avanços científicos e os novos conhecimentos sobre a natureza devem suscitar praticas diferente, visto que a natureza tem dado sinais de esgotamento sinalizando para o entendimento que os modelos de exploração da atualidade são nocivos para todos os seres vivos, principalmente o ser humano e que comprometem cada vez mais a qualidade e a disponibilidade destes recursos. 
7 Referências bibliográficas

AB'SABER. Aziz Nacib. PLANTENBERG. Clarita Mulher (org.) Previsão de Impactos. $2^{\circ}$ edição, São Paulo: Edusp, 1998.

ABREU. K. M. P.; COUTINHO. L. M. Sensoriamento remoto aplicado ao estudo da vegetação com ênfase em índice de vegetação e métricas da paisagem. VÉRTICES, v.16, n.1, p. 173-198, jan./abr. 2014

ALVIM, A. T. B., BRUNA, G. C. e KATO, V. R. C. Políticas ambientais e urbanas em áreas de mananciais: interfaces e conflitos. Cadernos Metrópole 19. São Paulo: EDUC, 2008.

ANDERSON, P. S. (Eds.). Princípios de Cartografia Básica. IBGE: 1982, vol. 1

ANDRADE, C. D. Mata Atlântica. 2a edição. Rio de Janeiro: AC\&M Ed: Sette Letras, 1997.

ARCHELA, R. S. Contribuições da Semiologia Gráfica para a Cartografia Brasileira. Geografia, Londrina, v. 10, n. 1, p. 45-50, jan./jun. 2001

ARCHELA, R. S.; ARCHELA, E. Correntes da cartografia teórica e seus reflexos na pesquisa. Geografia - Volume 11 - Número 2 - Jul/Dez. 2002

ARCHELA, R. S.; Théry. H. Orientação metodológica para construção e leitura de mapas temáticos. Confins [Online], 3, 2008.

ARCHELA, R. S. (et. al.) Abordagem Metodológica para Cartografia Ambiental. Portal de Cartografia. www.uel.br/projetos/cartografia, 2001. Acesso 20 de jan. 2014

ARRUDA, H. M. R. F. Cartografia de síntese para análise integrada da paisagem do município de São Gabriel/ RS: uma proposta de zoneamento ambiental. Santa Maria, dissertação (mestrado). Centro de Ciências Naturais e Exatas Programa de Pós-Graduação em Geografia e geociências, 2011.

ARRUDA. M. B. SÁ. L. F. N. (org.) Corredores ecológicos: uma abordagem integradora de ecossistemas no Brasil. Brasília: Ibama, 2003.

BRAGA. B. (et al.). Introdução à engenharia ambiental. São Paulo: Prentice Hall, 2002 
BERTIN, Jacques. La graphique. In: Communications, 15, 1970.

BERTIN, Jacques. La Graphique et le traitement graphique de l'information. Paris: Flammarion, 1977

. Neográfica e o tratamento gráfico da informação. Curitiba: Universidade Federal do Paraná, 1986.

. Ver ou ler. Seleção de Textos (AGB), São Paulo, n.18, p. 45-62, maio, 1988.

BERTIN, Jacques. Théorie de la communication et théorie graphique. Melanges Charles Morazé, Toulouse: PRIVAT, 1978, 6p. (trad. port. de Marcello Martinelli, Teoria da comunicação e teoria da representação gráfica, São Paulo, DG/USP, 1989).

BERTIN, Jacques. O teste da representação gráfica. Revista Brasileira de Geografia. IBGE: Rio de Janeiro, 42 (1): 160-182, 1980

BERTIN, Jacques; GIMENO, Roberto. A lição de cartografia na escola elementar. Boletim Goiano de Geografia, Goiânia: UFG, v. 2(1), p. 35-56, 1982.

BERTONI, J.; LOMBARDI NETO, F. Conservação dos solos. $4^{\text {a }}$ edição. São Paulo: Ícone, 1999.

BESSE. Jean - Marc. Ver a Terra: seis ensaios sobre a paisagem e a Geografia. São Paulo: Perspectiva, 2014

BORD, Jean-Paul. Jacques Bertin et les geographes. Point de vue d'un géographe cartographe. Disponível em: http://icaci.org/files/documents/ICC_proceedings/ICC2011/Oral\%20Presentations\%20PDF/A 3-Jacques\%20Bertin\%20and\%20graphic\%20semiology\%201/CO-018.pdf. Acesso em 15 de Dezembro de 2014

CÂMARA. I. G. Plano de ação para a Mata Atlântica. Rio de Janeiro: Fundação SOS Mata Atlântica, 1991.

CÂMARA. G. Representação computacional de dados geográficos. INPE: Bancos de Dados Geográficos. São José dos Campos, 2005.

CAPRA, Fritjof. O ponto de mutação. São Paulo: Edgard Blücher, 1982. 
CASSETI, Valter. Ambiente e Apropriação do Relevo. São Paulo: Contexto, 1991.

Geomorfologia. [S.1.]: [2005]. Disponível em: <http://www.funape.org.br/geomorfologia/>. Acesso em 10 de jan. de 2014.

CASTRO. Iná Elias. Análise geográfica e o problema epistemológico da escala. Anu. Inst. Geociências. v.15, Rio de Janeiro, 1992.

Solidariedade Territorial e Representação. Novas questões para o pacto federativo nacional. Revista TERRITÓRIO, 1(2), 1997.

CAVALCANTI. L. C. S. Cartografia de paisagens: fundamentos. São Paulo: Oficina de Textos, 2014.

CHRISTOFOLETTI, A. Geomorfologia. São Paulo: Eggard Blucher, 1980.

. Perspectiva da Geografia. São Paulo: Difel,1982.

- Significância da teoria de Sistemas em Geografia Física. Boletim de Geografia Teorética, vol. 16-17, $\mathrm{n}^{\circ}$ 1986-1987.

Aplicabilidade do Conhecimento Geomorfológico nos Projetos de Planejamento. In: GUERRA, A. J. T; CUNHA, S. B. (Org.). Geomorfologia: Uma Atualização de Bases e Conceitos. São Paulo: Bertrand Brasil, 1994, p. 415-436

CORREA, Roberto Lobato (Orgs.). Geografia: conceitos e temas. Rio de Janeiro: Bertrand Brasil, 1995.

. Diferenciação sócio-espacial, escala e práticas espaciais. CIDADES, v. 4, n. 6, 2007, p. 62-72, Rio de Janeiro.

CUNHA. Sandra Batista; GUERRA. Antônio Teixeira (org.) Geomorfologia: uma atualização de bases e conceitos. $2^{\circ}$ Edição - Rio de Janeiro: Bertrand Brasil, 1995.

Avaliação e perícia ambiental. $2^{\circ}$ edição - Rio de Janeiro: Bertrand Brasil, 2000.

CUNHA, C. M. L., MENDES, I. A., \& SANCHEZ, M. C. A Cartografia do Relevo: Uma Análise Comparativa de Técnicas para a Gestão Ambiental. Revista Brasileira de Geomorfologia, Ano 4, No 1 (2003) 01-09. 
DALMOLIN, R. S. D.; GONÇALVES, C. N.; KLAMT, E.; DICK, D. P. Relação entre os constituintes do solo e seu comportamento espectral. Ciência Rural, Santa Maria, v. 35, n. 2, p. 481 - 489, mar-abr, 2005. ISSN 0103-8478.

DEAN. W. A ferro e fogo: a história e a devastação da Mata Atlântica brasileira. São Paulo: Companhia da Letras, 1996.

DE BIASI, Mario. Carta de declividade de vertentes: confecção e utilização. Geomorfologia, Instituto de Geografia-USP, São Paulo, n. 21, p. 8-13, 1970.

A carta clinográfica: os métodos de representação e sua confecção. Revista do Departamento de Geografia, São Paulo, n. 6, p. 45-61, 1992.

DE BIASI, Mario; SIMIELLI, Maria Elena. R.; et al. Cartas de orientação de vertentes: confecção e utilização. Cartografia, Instituto de Geografia-USP, São Paulo, n. 4, p. 1-12, 1977.

DE BIASI, Mario; CUNHA, Keith Bento da. Cartas de energia do relevo: sua confecção e utilização. Boletim Goiano de Geografia, Goiânia, v. 3, n. 1/2, p. 195-200, jan./dez. 1983.

DUARTE. P.A. Conceituação de Cartografia Temática. GEOSUL, $n^{\circ} 11-$ Ano VI $-1^{\circ}$ semestre de 1991.

Fundamentos de Cartografia. Santa Catarina: Ed. UFSC, 1996.

EMPLASA. Atlas de Uso e Ocupação do Solo do Município de Juquitiba. São Paulo: Secretaria de Estado e planejamento, 2006.

FLORENZANO. Tereza Gallotti. Geotecnologias na Geografia aplicada: difusão e acesso. In: Revista do Departamento de Geografia, 17 (2005) 24-29.

Imagens de satélites para estudos ambientais. São Paulo: Oficina de Textos, 2002.

FONSECA, Fernanda Padovesi. A inflexibilidade do espaço cartográfico, uma questão para a Geografia: análise das discussões sobre o papel da Cartografia. São Paulo, Tese (Doutorado em Geografia), FFLCH/USP, 2004. Disponível em: http://www.teses.usp.br/teses/disponiveis/8/8135/tde-09082010-130954/pt-br.php. Acesso em 20 de Ago. de 2013 
FOnSECA. F. P.; OlIVA. J. Cartografia (coleção Como eu ensino). São Paulo: Melhoramentos, $1^{\text {a }}$ ed., 2013.

GEORGE, Pierre Os Métodos da Geografia. 2a ${ }^{\text {a }}$ ed. São Paulo: DIFEL, 1986

GIRARDI, Gisele. Leitura de mitos em mapas: um caminho para repensar as relações entre Geografia e Cartografia. Geografares (Vitória), Vitória, v. 1, p. 41-50, 2000. Disponível em: http://periodicos.ufes.br/geografares/article/view/1162. Acesso em 10 de out. 2013

GOMES, Paulo C. da C. Geografia e modernidade. Rio de Janeiro: Bertrand Brasil, 1996.

GREGORY. K. J. A natureza da geografia física. São Paulo: Bertrand Brasil, 1992.

GUERRA. José Teixeira. Geomorfologia e meio ambiente. Rio de Janeiro: Bertrand Brasil, 1966.

GUERRA. José Teixeira (org.) Erosão e conservação dos solos: conceitos, temas e aplicações. Rio de Janeiro: Bertrand Brasil, 1999.

GUERRA. A. J. T.; CUNHA. S. B. Geomorfologia e meio ambiente. $8^{\circ}$ edição, Rio de Janeiro: Bertrand Brasil, 2010

GUERRA. A. J. T. Dicionário Geológico - Geomorfológico. $8^{\text {a }}$ edição, Rio de Janeiro: IBGE, 1993.

. Degradação dos solos no Brasil. Rio de Janeiro: Bertrand Brasil, 2014.

HARLEY, J. B.; WOODWARD, D. (Eds.). The History of Cartography: Cartography in Prehistoric, ancient, and Medieval Europe and the Mediterranean. Chicago: University of Chicago Press, 1987. v. 1.

HARLEY, J. Brian. A nova história da cartografia. O Correio da UNESCO (Mapas e cartógrafos), Brasil: ano 19, n. 8, ago. 1991.

HARLEY, Brian. Mapas, saber e poder, Confins [Online], 5 | 2009, posto online em 24 abril 2009. Traduzido por Mônica Balestrin Nunes. Disponível em http://confins.revues.org/index5724.html Acesso em 20 out. 2013. 
HARTSHORNE, Richard. Propósitos e natureza da geografia. São Paulo: Hucitec/Edusp, 1978.

HIRATA, Ricardo. Gestão dos recursos hídricos subterrâneos. In: BENJAMIN, Antonio Herman (Org.). Anais do $7^{\mathbf{0}}$ Congresso Internacional de Direito Ambiental: direito, água e vida. São Paulo: Imprensa Oficial, 2003. v. 1.

INSTITUTO BRASILEIRO DE GEOGRAFIA E ESTATÍSTICA. IBGE Cidades. Disponível em: http://www.ibge.gov.br/cidadesat/topwindow.htm?1. Acesso 24 out. 2012.

. Carta Topográfica Juquitiba, folha SF 23-Y-C-V-4, Rio de Janeiro, 1984.

. Carta Topográfica Jurupará, folha SF 23-Y-C-V-3, Rio de Janeiro, 1984.

1984.

. Carta Topográfica Rio São Lourencinho, folha SG 23-V-A-II - 2, Rio de Janeiro,

JENSEN. J. R. Sensoriamento remoto do ambiente: uma perspectiva em recursos terrestres. São José dos Campos: Parêntese, 2009.

JOLY. Fernand. A Cartografia. Campinas: Papirus, 1990.

KAWAKUBO, F. S.; CAMPOS, K. C.; MORATO, R. G.; LUCHIARI, A. Cartografia da fragilidade ambiental com uso de técnicas de sensoriamento remoto e de análise espacial. In: Seminário De Pesquisa Em Geografia, 1, 2003, São Paulo. Anais... São Paulo: USP, 2003.

KUPLICH. T. M. Estudos florestais com imagens de RADAR. In: Espaço e Geografia, v. 6, $\mathrm{n}^{\circ} 1$ p. 65-90, 2003.

LEMOS. A. I. G.; GALVANI (org.) Geografia, tradições e perspectivas: interdisciplinaridade, meio ambiente e representações. $1^{\circ}$ Ed. São Paulo: Expressão Popular, 2009.

LEPSCH, I. F. Formação e Conservação dos Solos. São Paulo: Oficina de Textos, 2010

LÉVY, Jacques. Uma virada cartográfica? In: ACSELRAD, Henri (org.). Cartografias sociais e território. Rio de Janeiro: UFRJ/IPPUR, 2008. p. 153-167. 
LIBAULT. A. Tendências atuais da cartografia. Boletim Paulista de Geografia, $N^{\circ}$ 44, São Paulo, 1967.

. Os quatro métodos da pesquisa geográfica. Métodos em Questão, USP, IGEOG, São Paulo, nº 1, 1971.

. Geocartografia. São Paulo: Nacional/EDUSP, 1975.

LIMA, W.P. Hidrologia florestal aplicada ao manejo de bacias hidrográficas. 2 edição, Piracicaba-SP. Escola Superior de Agricultura "Luiz de Queiroz", 2008. 253p

LONGLEY. P. A. (et al.) Sistemas e Ciência da Informação Geográfica. $3^{a}$ Ed., Porto Alegre: Bookman, 2013.

LOUZADA. F. L. R. O. Análise da Cobertura Florestal por meio da subtração de imagem NDVI na Floresta Nacional de Pacotuba, Cachoeiro de Itapemirim, ES. Anais: Simpósio Brasileiro de Sensoriamento Remoto, 14. 2009

LÖWY, Michael. (1985) Ideologias e Ciência Social: elementos para uma análise marxista. São Paulo: Cortez,19a ed, 2010.

MARTINELLI, M. Orientação semiológica para as representações da Geografia: mapas e diagramas. In: Revista Orientação (8). São Paulo: IGEOG-DG/USP, 1990, p.55 a 62.

Curso de Cartografia Temática. São Paulo: Contexto, 1991.

. Cartografia ambiental: uma cartografia diferente. In: Revista do Departamento de Geografia, vol. 7, 1994.

As representações gráficas da Geografia: os mapas temáticos. Tese de Livre Docência. São Paulo: DG/FFLCH/USP, 1999.

1999.

. Alfabetização cartográfica. Boletim de Geografia. Maringá, DG/UEM, Ano 17, n.1,

Um breve apanhado sobre a breve história da cartografia temática. $3^{\circ}$ Simpósio

Iberoamericano de História da Cartografia, São Paulo, 2010.

. Mapas da Geografia e cartografia temática. 5ª edição, São Paulo: Contexto, 2010. 
MARTINELLI M.; PEDROTTI. F. A cartografia das unidades de paisagem: questões metodológicas. Revista do Departamento de Geografia, 14, 2001.

MARTINELLI, M. e QUEIROZ FILHO, A.P. Cartografia de análise e de síntese na geografia. Boletim Paulista de Geografia, v. 01, ano 2007.

MATIAS. Lindon Fonseca. Por uma cartografia geográfica - uma análise da representação gráfica na geografia. São Paulo, Dissertação (Mestrado em Geografia), FFLCH/USP, $1996 . \quad$ Disponível em: http://www.ige.unicamp.br/geoget/acervo/teses/Por\%20uma\%20Cartografia\%20Lindon.pdf. Acesso em 10 dez. 2014.

MELO, A. C. G.; DURIGAN, G. Evolução estrutural de reflorestamentos de recuperação de matas ciliares no Médio Vale do Paranapanema. Scientia Forestalis, Piracicaba, n. 73, p. 101-111, mar. 2007.

MELAZZO. E. S.; CASTRO. C. A. A escala geográfica: noção, conceito ou teoria? Terra Livre, Presidente Prudente, v.2, nº 29, 2007.

MENEZEZ. P. M. L.; NETO. A. L. C. Cartografia geoecológica: uma análise de conceitos. Disponível: http://www.geocart.igeo.ufrj.br/pdf/trabalhos/2001/Cart_Geoecologica_2001.pdf. Acesso em 22 jan. 2015

MENEZEZ. P. R.; ALMEIDA T. (org.). Introdução ao processamento de imagens de sensoriamento remoto. Brasília: UNB/CNPQ, 2012.

MILLER, K.R. Evolução do Conceito de Áreas de Proteção - Oportunidades para o século XXI. In: I Congresso Brasileiro de Unidades de Conservação. Curitiba: UNILIVRE, RS. Anais: v. 1, 3-21, 1997.

MORAES. A. C. R. Geografia: pequena história crítica. $21^{a}$ edição, São Paulo: Anablume, 2007.

- Notas sobre formação territorial e políticas ambientais no Brasil. In: Revista Território. Rio de Janeiro: ano IV, n 7, p. 43·50, jul./dez. 1999.

MONTEIRO, M.P.; SAWYER, D. Diagnóstico demográfico, socioeconômico e de pressão antrópica na região da Amazônia Legal. In: CAPOBIANCO, J.P.R. (coord.). Biodiversidade na Amazônia brasileira: avaliação e ações prioritárias para a conservação, uso sustentável e repartição de benefícios. São Paulo: Instituto Socioambiental, 2001. 
MONTEIRO, C.A. A questão Ambiental no Brasil. São Paulo: Editora IG-USP, 1981

MOTA, S. Urbanização e meio ambiente. Rio de Janeiro: Fortaleza, ABES, 2011.

MULLER, C.C. Gestão das matas ciliares. In: LOPES, I.V. et al. (ed.). Gestão ambiental no Brasil: experiência e sucesso. 3. edição. Rio de Janeiro: Fundação Getúlio Vargas, 2000. p. $185-214$.

NETO. Antônio Teixeira. Haverá, também, uma Semiologia Gráfica? Boletim Goiano de Geografia, no 4, 5, 6; p. 13-54, 1984/1985/1986.

ODUM. Eugene P. Fundamentos de ecologia. $7^{\circ}$ edição, Lisboa, Fundação Gulbenkiam, 2004.

OLIVEIRA. C. Curso de cartografia moderna. $3^{\circ}$ edição, Rio de Janeiro: IBGE, 1993.

OLIVEIRA. L. O Estudo metodológico e cognitivo do mapa. IGEOG - USP, nº 32, 1978.

PEREIRA. J. B. S.; ALMIDA. J. R. Biogeografia e geomorfologia. In: GUERRA. A. J. T.; CUNHA. S. B. Geomorfologia e meio ambiente, $8^{a}$ edição, Rio de Janeiro: Bertrand Brasil, 2010

OZENDA, P. La cartographie écologique et ses applications. Paris: Masson, 1986.

. Eléments géographiques et endémisme dans les Alpes Maritimes et Ligures. In: Bulletin de la Société Botanique de France, 2014

- Les relations biogéographiques des montagnes sahariennes avec la région méditerranéenne. In: Revue de géographie alpine. 1991, Tome 79, ํ⒈

Les séries de végétation de la chaine alpine et leurs équivalences dans les autres systèmes phytogéographiques. Documents de Cartographie Ecologique, vol. XVI, 1975.

PIRES, J. S. R.; SANTOS, J. E.; DEL PRETTE, M. E. A utilização do conceito de bacia hidrográfica para a conservação dos recursos naturais. In: SCHIAVETTI, A.; CAMARGO A. F. M. (Eds.). Conceitos de bacias hidrográficas: teorias e aplicações. Ilhéus, BA: Editus, 2002. 293p. 
PONZONI, F. J. Sensoriamento Remoto no estudo da vegetação: diagnosticando a mata atlântica. São José dos Campos: INPE, 2002.

PRIMAC. R. B; RODRIGUES. Efrain. Biologia da Conservação. Londrina: Rodrigues, 2001.

PRUSKI F. F.; CECÍLIO. R. A. Interpolação dos parâmetros da equação de chuvas intensas com uso do inverso de potências da distância. In: Revista Brasileira de Engenharia Agrícola e Ambiental, v.7, n.3, 2003, p.501-504.

QUEIROZ. Deise Elias Regina. A Semiologia e a Cartografia Temática. Boletim de RAISZ. Erwin. Cartografia Geral. Rio de Janeiro: Editora Científica, 1969.

(1), 2007.

. Cartografia Temática: evolução e caminhos de pesquisa. Boletim de Geografia; 25

RATAJSKI. L. Les caracteristiques principales de La comunication cartographique em taint que partie de La cartographie théorique. In: Bulletin du Comité Français de Cartographie, $\mathrm{n}^{\circ} 7,1978$.

RIMA. Estudo de concepção e projeto básico do sistema produtor São Lourenço. São Paulo: SABESP, 2011.

RICKLEFS. R. E. A economia da natureza. $5^{a}$ edição. Rio de Janeiro, Guanabara Koogan, 2003.

ROSA, Flávio Sammarco. Impactos da informática na Cartografia. In: Simpósio internacional sobre novas tecnologias digitais em geografia e cartografia, 1996, São Paulo, Anais. São Paulo: LEMADI, 1996. p. 34-39.

ROSA, Roberto. O uso de SIG's para o zoneamento: uma abordagem metodológica. São Paulo: FFLCH/USP, 1995, 225p. (Tese de Doutoramento).

ROSS, J. L. S. Relevo brasileiro: uma nova proposta de classificação. Revista do Departamento de Geografia da USP, São Paulo, n. 4, 1985.

ROSS, J. S. Geomorfologia: Ambiente e Planejamento. In: OLIVEIRA, A. U. (Org.). Coleção repensando a Geografia. São Paulo: Contexto, 1990. 
ROSS, J. L. S. O registro cartográfico dos fatos geomórficos e a questão da taxonomia do relevo. Revista do Departamento de Geografia, n. 6, 1992.

ROSS, J. L. S. Análise empírica da fragilidade dos ambientes naturais e antropizados. Revista do Departamento de Geografia, n.8, p.63-74, 1994.

ROSS. J. S. (org.). Geografia do Brasil. 6a edição, São Paulo: Edusp, 2009.

Ecogeografia do Brasil: subsídio para o planejamento ambiental, São Paulo: Oficina de Textos, 2009.

ROSS, J. L. S. Geografia do Brasil. $4^{a}$ edição. São Paulo: Edusp, 2001.

SALES. V. C. Geografia, sistemas e análise ambiental: abordagem crítica. São Paulo: GEOUSP - Espaço e Tempo, No 16, p. 125 - 141, 2004.

SANTOS. C. A.; FLORENZANO. T. G; NORA. E. L. D. Estudo geológico-geomorfológico da sub-bacia leste do Araripe com aplicação de variáveis morfométricas derivadas a partir de dados SRTM. Simpósio Brasileiro de Sensoriamento Remoto, Natal, Brasil, 25-30 abril 2009.

SANTOS. R. F. Planejamento Ambiental: Teoria e prática. São Paulo: Oficina de Texto, 2004.

SERRÃO, H. O mecanicismo: Descartes e Newton. Filosofia e Ciências da natureza 8: Descartes e o mecanicismo. Logosfera, 2007. Disponível em:<http://filosofialogos.blogspot.com.br/2007/07/filosofia-e-cincias-da-natureza-8.html>. Acesso em 25 ago. 2015.

SILVEIRA. MARÍA LAURA. Escala geográfica: da ação ao império? Terra livre, Vol. 2 Número 23, 2004.

SMITH, Neil. Geografia, diferencia y políticas de escalas. Terra Livre, São Paulo: Ano 18, n. 19 p. 127-146 jul. /dez. 2002.

SOTCHAVA, V.B. O estudo dos Geossistemas. Métodos em Questão, vol. 16, 1976.

Por uma teoria de classificação de geossistemas de vida terrestre. São Paulo: Instituto de Geografia da USP, 1978. 
SOUZA. T. A. Uma Contribuição ao Conhecimento Geomorfológico do Litoral Paulista, Rio Claro: Universidade Estadual Paulista, 2008.

SPÖRL, C. E ROSS, J.L.S. (2004): Análise da fragilidade ambiental com aplicação de três modelos. In: GEOUSP - espaço e tempo. São Paulo, n 15, São Paulo, p. 39-49.

SUHOGUSOFF, V. G.; PILIACKAS, J. M. Breve Histórico da Ação Sobre os Ecossistemas Costeiros do Brasil, com Ênfase nos Manguezais do Estado de São Paulo. Integração, ano XIII, 51: 343-51, 2007.

TAYLOR, D.R.F., 1991. A Conceptual Basis For Cartography: New Directions For The Information era. Cartographica. Toronto: University Toronto Press, v.28, $\mathrm{n}^{\mathrm{o}} 24$.

THEODOROVICZ, A. GODOY. A.M. Atlas geoambiental: subsídios ao planejamento territorial e à gestão ambiental da bacia hidrográfica do rio Ribeira do Iguape. $2^{\text {a }}$ edição revisada, São Paulo: CPRM, 2007.

TRICART, J. Principes et Méthodes de La Géomorphologie, Paris: Masson et Cie, 1965.

. Ecodinâmica. Rio de Janeiro: FIBGE/Supren., 1977.

. Terra planeta vivo. Lisboa: Editora Presença, 1978.

TROPPMAIR. H.; GALINA. M. H. Geossistemas. Mercator - Revista de Geografia da UFC, ano 05, número 10, 2006.

TUCCI, C. E. M. Modelos Hidrológicos. Porto Alegre: Edit. UFRGS - ABRH, 1998.

TUNDISI. J. G. Água no século XXI: enfrentando a escassez. São Carlos: RIMA, IIE, 2005.

VICTOR, M. A. M. et al. Cem anos de devastação: Revisitada 30 anos depois. Ministério do Meio Ambiente. Secretaria de Biodiversidade e Florestas. Brasília: Ministério do Meio Ambiente, 2005.

ZACHARIAS. A. A. As categorias de análise da cartografia no mapeamento e síntese da paisagem. Revista Geografia e Pesquisa - v.2 - n.1, pp. 33-56, jan-jun 2008. 